\title{
324\%E DESTUURSVERGADRRING,
}

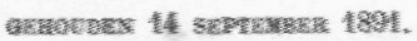

Tegenwoordig de heeren der Kinderen (Voorzitter), L. W. C. van den Derg, Kielstra, Niemana, Quarles van Ufford, Vreede en Wijumalea (Beeretaris). Mede aanwezig het oudBestuurshil Martin Afrerig, met kemiggeving; de heeren N. P. ran den Berg, de Groot, ran der Pant en Behlegel.

De notalen ran het rerhandelde in de vorige vergodering worden gelesen en guedgekenrl, wama de Voorzitter de leden welkw heet bị de hervatting der werkzaamheden na het gewone zomerreces. Met weemoed echter ziet hij eene plaats onbezet, ingenomen door het Bestuurslid, Prof. Dr. G. A. Wilken, den 28 Augustus jl. te Leiden in den ouderdom van 44 jaren overleden, aan wiens verdiensten zoowel op het gebied der ethnografische wetenschap in het algemeen als voor het Instituut in het bizonder de $\boldsymbol{\Gamma}$ oorzitter een warm woord van hulde wijdt, onder mededeeling wijders, dat aan de Weduwe, na ontvangst der kennisgeving van het overlijden van haar Echtgenoot, een brief van rouwbeklag is verzonden, terwijl het Bestuur bij de begrafenisplechtigheid vertegenwoordigd werd door den Voorzitter, Secretaris en Penningmeester, benevens door de leden Kielstra en Vreede; eerstgenoemde sprak daarbij uit naam van het Instituut een woord van hulde aan de nagedachtenis van den overledene.

De Voorzitter deelt nog mede, dat van het buitenlandsch lid Prof. F. Blumentritt in Leitmeritz (Bohemen) een schrijven is ontvangen, waarin deelneming wordt betuigd over het overlijden des heeren Wilken; aan zijn verzoek om eenige gegevens te ontvangen voor eene necrologie door hem in een Spaansch orgaan te plaatsen, is bereids door den Secretaris voldaan

Op verzoek van den Voorzitter geeft de Secretaris een overzicht van hetgeen sedert de laatste vergadering ter bevordering 
der wetenschappelijke reis des heeren Martin is verricht, waaruit blijkt :

10. dat is ontvangen een Extract uit het Register der Besluiten van den Gouverneur-Generaal van Nederlandsch-Indië, d.d. Buitenzorg, den 16den Juni 1891, no. 23, luidende:

\section{"Gelet enz.}

"De Raad van Nederlandsch-Indie gehoord.

"Is goedgevonden en verstaan:

"Eerstelijk: Aan'het Koninklijk Instituut voor de taal-, land- en volkenkunde van Nederlandsch-Indie te 's Gravenhage gedurende het jaar 1891 toe te kennen een subsidie van $f 5000$ (vijf duizend gulden), ten einde het genootschap in staat te stellen met behulp van dit bedrag een aanvang te maken met een door de Hoogleeraren Dr. K. Martin en Dr. G. A. Wilken in te stellen wetenschappelijk onderzoek van de eilanden der Banda-zee;

"onder voorwaarde dat de bij het onderzoek te maken verzamelingen, na voor zooveel noodig bewerkt of beschreven te zijn, ter

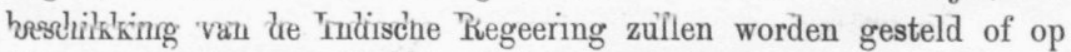
Hare aanwijzing aan Nederlandsche musea zullen worden afgestaan.

"Ten tweede: Aan het Koninklijk Instituut voornoemd te kennen te geven dat de Regeering genegen is, verzoeken om nadere subsidies ter voortzetting van het bovenomschreven onderzoek gedurende de jaren 1892 en 1893 in gunstige overweging te nemen, ingeval de begrootingen dier jaren daartoe gelegenheid geven.

"Ten derde: enz.

"Extract dezes zal worden verleend aan het Koninklijk Instituut voor de taal-, land- en volkenkunde van Nederlandsch-Indië tot informatie. "Accordeert met voors. Register.

\section{De Gouvernements-Secretaris,}

D. F. UhLENBECK."

620. dat onverwijld na ontvangst van dit besluit van den inhoud daarvan is kennis gegeven aan den hoogleeraar Dr. Martin, die daarop. aan de Regeering verlof voor den tijd van éen jaar heeft aangevraagd en verkregen.

30. dat door het Bestuur zoowel bij de Directie van de Stoomvaartmaatschappij "Nederland" als bij die van de Koninklijke Paketvaart-Maatschapppij de noodige stappen zijn gedaan om reductie op de overtochtskosten te mogen erlangen. Eerstgenoemde Directie verklaarde zich bij schrijven van 14 Juli jl. lett. D. no. 1092 gaarne 
bereid dezelfde reductie van 20 pCt. van het tarief voor particuliere passagiers toe te staan, als zij reeds sedert geruimen tijd toepast op de overtochten van hen, die voor een erlend wetenschappelijke Vereeniging de reis naar Java ondernemen, terwijl doot de Koninklijke Paketvartmatsehappij, byj missive van 20 Juli jl. $\mathrm{n}^{6} .266 \mathrm{~V}$. eene reductie van $25 \mathrm{pCt}$. zal worden toegestasn op het passage tarief zoowel als op de overvracht der bagage, indien men zich dastoe tot den Hoofdagent te Batavia wenden wilde.

40. dat, als gevolg van een en ander, voor den heer Martin plats besproken is op het stoomsehip "Koningin Emma", dat 24 September e. $k$. van Genua naar Indiê zal vertrekken, terwjil door den heer Martin bereids de noodige maatregelen zijn genomen voor zijne uitrusting en tot het aansehaffen van de noodige hulpmiddelen vour zijn onderzoekingsreis.

50. dat, zal de voorgenomen onderzoekingsreis kans van welslagen asmbieden, zij vooral den steun behoeft van de Indische autoriteiten en wetenschappelijke Instellingen, ter verkrijging waarvan het Bestuw zich selriftelijk heet gewend tot den GouverneurGenerasl, den Diredenr wan het Departement ran Onderwijs, Beredienst en Nijverheid, den Hesident van Amboina, het medelid G. W. W. O. Baron van Hoërell, den Hooflagent van de Koninklijke Paketvasat-maatschappij te Batavia en de Directienn van het Bataviaasch Genootselup wan Kunsten en Wetenschappen en van de Koninklijke Naturkundige Vereeniging van N. I. to Batavia.

De verschillende brieven asn deze Antoriteiten en Instellingen geschreven, worden achtereenvolgend der vergadering medegedeeld.

60. dat, ter bestrijling der vele gedane m nog te verrichten nitgaven, an den Minister wan Koloniên het verzoek is gedan het toegestaan creliet van $f 5000$ hier to lande boschikbast te stellen; an welk verzoek asnstonds is voldan, terwijl bereids over het bedrag is beschikt en dit den Penningmeester is ter. hand gesteld, die daarop asn den heer Martin het noodige crediet heeft verstrekt, onder gehoudenheid zijnerzijds eener later in te dienen rekening en venutwoording wan de dow hem besteedde gelden.

De Voorzitter dankt den Secretaris voor zijne mededeelingen en zegt dat de vergadering, tot bijwoning warvan de lece Martin is genoodigd, is belegd ten einde hem in de gelegenheid te stellen cenige inlichtingen te geven omtrent zijne voomemens en tevens een financiede regeling to treffen, wasdoor zijn onderzoek bij den asnvang van 1892 voldoende zon kumen worden verzekerd. 
De heer Martin, hierop het woord verkregen hebbende, geeft een overzicht van zijn reisplan, waaruit blijkt, dat, waar hij in het laatst van September zal vertrekken, vermoedelijk tegen het einde van October te Batavia zal kunnen aankomen, alwaar hem de medewerking van Dr. Treub bereids is toegezegd. Na een kort verblijf te Batavia, ter bespreking en toelichting van zijn onderzoek bij de antoriteiten, stelt hij zich voor in den aanvang van November naar Amboina te kunnen vertrekken, om bij aankomst aldaar, aanstonds het geognostisch onderzoek op dit eiland in te stellen en daarna, na gehouden overleg met den Resident van Amboina, met hetzelfde doel naar Boeroe, Ceram, zoo mogelijk ook naar de Zuidwestereilanden te gaan. Het hem voor het onderzoek toegestaan crediet zou echter spoedig blijken uitgeput te zijn, althans zoo hij een bedrag moest reserveeren voor zijne terugkomst, indien hij althans reeds bij den aanvang van het volgende jaar moest terugkeeren, zoo de Regeeringssubsidie, die in uitzicht is gesteld, onverhoopt niet mocht worden uitgekeerd, of wellicht eerst laat ter beschikking van het Instituut gesteld. Daarom zou hij wenschen, dat het Instituut hem vóor zijn vertrek een credietbrief uitreikte, die hem in staat zou stellen, om, beginnende met Januari 1892, op Amboina door tusschenkomst der Hạndelsmaatschappij geld te ontvangen tot een bedrag van $f 6000$. Hij zou daarentegen de verplichting op zich nemen van den credietbrief geenerlei gebruik te zullen maken, voordat hem het bericht zal hebben bereikt dat de voor 1892 aan te vragen subsidie was toegestaan, terwijl hij in het tegenovergestelde geval, of wel bij eventueele verwerping van den post van $f 10.000$ door de Tweede Kamer, aanstonds zal terugkeeren.

Naar aanleiding dezer mededeeling wordt door al de Bestuursleden van gedachten gewisseld, waarbij het verstrekken van een credietbrief ongeraden wordt geoordeeld, doch daarentegen de heer Martin gemachtigd van het hem toegestaan crediet niets voor zijne onverhoopt vroegere terugkomst af te zonderen; 't eventueel daarvoor benoodigde bedrag zou het Instituut voor zijne rekening nemen; het Bestuur zal echter, zoo spoedig als dit oirbaar is, zich tot de Indische Regeering wenden met de aanvrage om nadere subsidies ter voortzetting van het omschreven onderzoek, zullende, zoo daarop eene gunstige beschikking wordt verkregen, tevens het verzoek worden gedaan om het bedrag der subsidie hetzij geheel hetzij gedeeltelijk aan 's Lands kas te Amboina beschikbaar te willen stellen.

Naar aanleiding eener vraag des heeren Martin over de indiening 
eener gedétailleerde rekening en verantwoording van het hem toegestaan crediet wordt medegedeeld, dat het niet in de bedoeling ligt zulk eene gespecificeerde opgave te ontvangen, waarbij elke uitgave, de geringste niet uitgezonderd, vermeld wordt.

De Voorzitter stelt verder de vraag aan de orde, of ten gevolge van het overlijden van den hoogleeraar Wilken de heer Martin thans alléen het voorgenomen onderzoek zal moeten instellen, dan wel of de taak, welke wijlen Prof. Wilken dacht te vervullen, door een ander moet worden verricht, en, zoo ja, aan wien dit alsdan zal worden opgedragen.

$\mathrm{Na}$ gedachtenwisseling wordt de Secretaris gemachtigd zich tot Dr. H. Ten Kate, die thans een onderzoekingstocht in Indië onderneemt, te wenden en hem, onder volledige mededeeling van het door het Instituut voorgenomen onderzoek, te vragen, of hij, na afloop van zijne reis, zich met de vervulling der taak, door wijlen Dr. Wilken aanvaard, zou willen belasten.

Hiermede de'bespreking van Dr. Martin's reize afgeloopen zijnde, wenscht de Voorzitter den heer Martin eene voorspoedige reis toe en een alleszins gelukkigen afloop van zijn onderzoek in het belang van de wetenschap in 't algemeen en van het Instituut in 't bizonder. Dr. Martin dankt den Voorzitter voor de door hem uitgesproken wenschen en verlaat de vergadering, na van de leden afscheid te hebben genomen.

De Secretaris doet opgave van de sedert de vorige vergadering ingekomen boekwerken en handschriften; en wat deze laatste betreft deelt hij mede, dat door welwillende tusschenkomst van den Rijksarchivaris een aantal bescheiden zijn ontvangen, afkomstig van den heer A. H. W. Baron de Kock, oud Vice-president van den Raad van Indië.

Terwijl voor dit geschenk bereids de dank van het Instituut is aangeboden, wordt besloten de handschriften in handen te stellen van het lid Kielstra om bericht en raad.

Nog wordt medegedeeld dat zijn ontvangen:

10. twee missives van de Minister van Binnenlandsche Zaken, dd. 27 Juli jl. no. 1683, afd. K. W. en 4 Augustus jl. no. 1756 afd. $\mathrm{K}$. W., ten geleide van eenige pakketten met boeken, ten vervolge voor het Instituut bestemd en ontvangen van de Fransche Commissie van Internationale ruiling te Parijs. 
20. eene missive van den Directeur van Onderwijs, Eeredienst en Nijverheid, te Batavia, van 11 Juli $] 891, \mathrm{n}^{0} .6948$, waarbij namens de Regeering van Nederlandsch-Indië wordt aangeboden een pakket, inhoudende 164 fotografieën van den voet van den Boroboedoer.

$3^{0}$. eene missive van de Directie van het Musée Guimet ten geleide van de Annales du Musée Guimet, Tome XVIII en de Revue de l'Hist. des Rel. T. XXIII no. 3.

40. eene missive van de Koninklijke Akademie der Wetenschappen te Amsterdam, waarbij wordt aangeboden een exemplaar der Verhandelingen, afd. Letterkunde, dl. XX; Verslagen en Mededeelingen, afd. Natuurk. 3e Reeks, dl. VIII, 3 en afd. Letterkunde, 3e Reeks, dl. VIII. 1, en prijsvers Maria Virgo, terwijl tevens een schrijven wordt bijgevoegd, houdende dankbetuiging voor de laatstelijk ontvangen Bijdragen van het Instituut, 5e Rks, dl. VI, afl. 1 en 2 en De Badoej's van J. Jacobs en J. J. Meyer.

50. eene missive van den Bibliothecaris van Teyler's Museum te Haarlem, houdende aanbieding van een exemplaar der Archives der Musée Teyler, série II, vol. III, fasc. 6 .

Plaatsing van al deze werken in de Bibliotheek, onder dankzegging aan de inzenders.

60. eene missive van de General-Verwaltung der Königlichen Museen te Berlijn, houdende dankbetuiging voor de toezending der Bijdragen van het Instituut.

7o. eene missive dd. 16 Juli 1891 van het Comité tot regeling van het 9e Internationaal Congres van Orientalisten, houdende noodiging tot deelneming aan het Congres, dat van 1 tot 10 September dezes jaars te Londen wordt gehouden.

80. eene missive van Mevr. de Wed. J. Heyting, te Bandong, houdende bericht van het overlijden van haren Echtgenoot J. Heyting,
Resident der Preanger-Regentschappen.

9o. missives van de hh. Storm van 's Gravesande, P. G. Schmidbamer, Ch. van Kerkhoff, J. van Hengst, E. Douwes Dekker, M. 
E. F. T. Dubois en C. Poensen, allen houdende bericht van de verandering hunner woonplaats.

$10^{\circ}$. eene missive van den heer H. Sundermann, waarbij hij zijn leedwezen betuigt over het besluit van het Bestuur tot het nietverstrekken eener subsidie voor de uitgave zijner Niassische studiën, onder mededeeling tevens dat hij, zoo hij er niet mocht slagen een uitgever daarvoor te vinden, gaarne gebruik zal maken van het aanbod om het vroeger reeds aangewezen gedeelte van zijn arbeid met daarbij gevoegde vertaling vanwege het Instituut te doen publiceeren.

Al deze missives, sub 90-110., worden voor kennisgeving aangenomen.

Ter tafel wordt gebracht een schrijven van den heer J. L. van den Toorn van den 12 September jl., waarbij hij mededeelt, dat hij na de voltooiing van het door hem bewerkte MinangkabauschMaleisch-Nederlandsch Woordenboek, waarvan de uitgave eerlang kan worden tegemoetgezien, zich weder voor den Indischen dienst moet beschikbaar stellen. In verband echter met evengemeld woordenboek heeft hij zich sedert eenigen tijd bezig gehouden met de vervaardiging van een Minangkabausch-Maleische spraakkunst, waarbij eene bloemlezing uit Minangkabausche geschriften: een werk waarvoor hij de voornaamste gegevens verzameld had tijdens zijn verblijf in de Padangsche Bovenlanden aan het hoofd van de Kweekschool voor Inlandsche onderwijzers te Fort de Kock, doch dat hij gedurende zijn verloftijd hier te lande onmogelijk kon beeindigen, aangezien de verdere bewerking en later de correctie van het vanwege het Instituut bezorgde Woordenboek hem daarvoor niet den noodigen tijd lieten. Voor de bewerking van die spraakkunst en zijne verdere studiën van de Minangkabausche taal zou hij zeer gaarne eene herplaatsing in de Padangsche Bovenlanden erlangen; hij vreest echter, dat hij bij zijne terugkomst in Indië 't zij bij het Europeesch onderwijs 't zij in eene andere betrekking zal worden geplaatst, waardoor hem alle gelegenheid zou worden benomen om zijne linguistische studiën voort te zetten. Reden waarom hij het Bestuur in overweging geeft zoodanige maatregelen te willen nemen, dat zijn wensch vervuld zoude kunnen worden en hij nog gedurende de enkele jaren van zijn diensttịjd in Indië voor de Minangkabausche taalwetenschap werkzaam zou mogen zijn. 
Onder warme aanbeveling van dit verzoek des heeren van der Toorn, nader toegelicht door den Secretaris, stelt de Voorzitter voor, dat het Bestuur van het Instituut zich wende tot den Minister van Koloniën ten einde zijne veelvermogende tusschenkomst bij de Indische Regeering in te roepen, dat deze aan den heer van der Toorn bij zijne terugkomst in Indië eene plaatsing verzekere, die hem de gelegenheid zal kunnen aanbieden tot voortzetting en voleindiging zijner studiën van de Minangkabausche taal.

Dienovereenkomstig wordt besloten.

De Secretaris deelt mede, door tusschenkomst van den hoogleeraar Kern, eene bijdrage van Dr. Groneman te hebben ontvangen over Tjandi Parambanan op Midden-Java na de ontginning, waarbij een aantal fotografiën zijn gevoegd, met verzoek een en ander vanwege het Instituut te publiceeren. Om bericht en raad in handen gesteld van het Bestuurslid Niemann.

Het Bestuurslid Quarles van Ufford vestigt de aandacht op een door Prof. Dr. R. Brandstetter te Lucern uitgegeven bijdrage, getiteld: "Charakterisirung der Epik der Malaien. Original Untersuchung" en geeft in overweging dat daarvan in het tijdschrift van het Instituut eene aankondiging of bespreking worde geleverd, waartoe hij voorstelt den hoogleeraar Dr. Kern. uit te noodigen. Dienovereenkomstig wordt besloten.

Herinnerend aan den herhaaldelijk uitgesproken wensch dat het Instituut in het bezit kome van een ruimer localiteit, deelt de heer Quarles van Ufford mede dat wellicht die wensch zou kunnen worden bevredigd, waar tengevolge van het overlijden van den Graaf van Hogendorp diens woning, gelegen aan de Lange Houtstraat, door de Erven zal worden verkocht. De Voorzitter, Penningmeester en Secretaris verklaren zich bereid ter gelegener tijd het bedoelde huis te gaan zien.

Het Bestuurslid L. W. C. van den Berg biedt voor de Bibliotheek een overdruk aan zijner in het Tijdschrift voor strafrecht geplaatste bijdrage "over het misdrijf van verkrachting in verband met het Mohammedaansche huwelijksrecht." De Voorzitter zegt hun dank voor zijn geschenk, waarna, verder niets meer aan de orde zijnde, de vergadering wordt gesloten. 


\section{STE BESTUURSVERGADERING,}

GEHOUDEN 17 OCTOBER 1891.

Tegenwoordig de heeren der Kinderen (Voorzitter), J. H. de Groot (Penningmeester), L. W. C. van den Berg, Kielstra, Niemann, Schlegel, Vreede en Wijnmalen (Secretaris). Afwezig, met kennisgeving, de heeren N. P. van den Berg, van der Pant en Quarles van Ufford.

De notulen van het verhandelde in de vorige vergadering worden gelezen en goedgekeurd.

Door den Secretaris-Bibliothecaris wordt mededeeling gedaan van de sedert de vorige bijeenkomst ontvangen boekwerken. Aangenomen voor kennisgeving.

Vervolgens deelt de Voorzitter mede, dat is ontvangen:

$1^{0}$. eene missive van de Directie van het Musée Guimet, te Parijs, ten geleide van een exemplaar der Revue de l'Hist. des Rel. T. XXIV, no 1.

20. eene missive van de Académie Royale des Sciences de Lisbonne, houdende kennisgeving van het overlijden van haren Secretaris José Maria Latino Coelho.

$3^{0}$. eene missive, waarbij wordt kennis gegeven van het overlijden van den Heer A. A. Bienfait, met verzoek het lidmaatschap te doen eindigen.

$4^{\circ}$. missives van de leden N. Adriani, H. C. Douwes Dekker, M. C. van Doorn, J. Ennen, H. A. de Nooy, C. Poensen en M. Paul Voute, allen houdende kennisgeving van de verandering hunner woonplaats.

Al deze missives worden voor kennisgeving aangenomen.

Tot leden van het Instituut worden voorgedragen en benoemd de heeren J. Faes, oud Resident, thans te Soekaboemi, en A. E. Mooyaart, Gepensioneerd Kapitein van het Ned. leger, te 's-Gravenhage.

Van den hoogleeraar Kern is een schrijven ingekomen, waarbij hij bezwaar maakt gevolg te geven aan de uitnoodiging om in een 
der afleveringen van de Bijdragen de aandacht te vestigen op het jongst verschenen geschrift der hoogleeraar Brandstetter, te Lucern over de Maleische letterkunde.

Voor kennisgeving aangenomen, terwijl besloten wordt dezelfde noodiging thans te richten tot den heer R. van Eck, leeraar in de Maleische taal- en letterkunde aan de Kon. Militaire Academie te Breda.

Ten vervolge op het schrijven van 10 Juni jl., nº. 1895, is van het Departement van Koloniën eene missive d.d. 9 October jl. Bureau T. no. 3433 ontvangen, waarbij namens den Minister wordt medegedeeld, dat, blijkens een uit Indië ontvangen bericht, aldaar nog 809 exemplaren van het $\mathrm{I}^{\mathrm{e}}$ en 1148 exemplaren van het $\mathrm{TIe}$ dl. van des heeren G. K. Niemann's Bloemlezing uit Maleische Geschriften in voorraad zijn, zoodat aan een herdruk van dat werk, ten behoeve van den Indischen dienst, voorshands geen behoefte bestaat. De Indische Regeering biedt aan om de helft van den aanwezigen voorraad ter beschikking van het Instituut te stellen tegen de prijzen waarvoor het werk in Indië verkrijgbaar is gesteld, t. w. $f 1.60$ voor het eerste, en $f 0.70$ voor het tweede deel, vermeerderd met de kosten van transport naar Nederland. De Minister zou gaarne vernemen of dit aanbod door het Instituut wordt aangenomen.

Naar aanleiding van dit schrijven wordt de opmerking gemaakt dat de vroeger voor den Indischen dienst bestemde exemplaren van des heeren Niemann's Bloemlezing de in het Nederlandsch opgestelde aanteekeningen missen, die voorkwamen in de hier te lande voor den handel bestemde en sedert uitverkochte exemplaren. Met het oog vooral op die omstandigheid wordt, na gedachtenwisseling, besloten in antwoord op het evenvermeld schrijven des Ministers mede te deelen, dat het daarin omschreven aanbod der Indische Regeering niet kan worden aangenomen.

De Secretaris deelt mede, dat de uitgave van het MinangkabauschMaleisch-Nederlandsch Woordenboek, bewerkt door den heer J. I. van der Toorn, voltooid is en brengt daarvan een exemplaar ter tafel, onder mededeeling wijders, dat, overeenkomstig een vroeger ontvangen beschikking, van deze uitgave 50 exemplaren aan het Departement van Koloniën zijn gezonden, met bijvoeging, ingevolge het ontvangen voorschrift, van eene declaratie voor de ten behoeve van de uitgave toegekeude subsidie, waarvan het bedrag, onverwijld 
is uitgekeerd en bereids aan den Penningmeester ter hand gesteld. De Secretaris legt tevens over de nota van de firma Brill betreffende de kosten van den druk van meergemelde uitgave, waartegen geene bedenking wordt gemaakt en die, goedgekeurd, aan den Penningmeester ter afdoening wordt in handen gesteld, terwijl, eindelijk, overeenkomstig het advies van den Penningmeester, het honorarium, aan den heer van der Toorn uit te keeren, wordt bepaald.

Bij schrijven van 5 October jl. deelt de uitgever M. Nijhoff mede, dat hij van de firma Brill 447 exemplaren van meergemeld Woordenboek heeft ontvangen, waarvan hij 347 exemplaren naar het locaal van het Instituut ten behoeve van het Fonds heeft gezonden, zoodat hij slechts 100 exemplaren in depôt houdt, terwijl hij voorstelt den prijs van het woordenboek op $f$. - per exemplaar te bepalen. Dienovereenkomstig wordt besloten, met dien verstande echter, dat tevens herinnerd zal worden, dat de leden van het Instituut het werk kunnen verkrijgen tegen de helft van den handelsprijs.

Het Bestuurslid Niemann brengt het volgend schriftelijk rapport nit: "In eene vorige affevering der Bijdragen (Vijfde volgreeks Dl. IV, bl. 636) staat reeds eene Rottineesche grammatica, in het Mal. geschreven door Manafe, onderwijzer te Baä op Rotti. De lezing van dit opstel gaf den onderwijzer te Babauw op Timor, een Rottinees, genaamd. Fanggidoej, aanleiding tot het opstellen van eene nieuwe spraakkunst van die taal, omdat, naar zijn inzien, die van Manafe al te beknopt en niet duidelijk genoeg was. Deze Grammatica van Fanggidoej, die ten fine van praeadvies in mijne handen is gesteld, is ongetwijfeld veel beter bewerkt dan de vorige van Manafe. Zij geeft een vrij volledig overzicht van de voornaamste verschijnselen der taal, nl. van het dialect Fermanu, dat men wel als het hoofddialect kan beschouwen. Natuurlijk blijft er altijd nog ruimte genoeg over tot nader onderzoek. Daar echter de Mal. taal, waarin zij is opgesteld, een minder geschikt voertuig is voor het schrijven van eene grammatica, zou eene vertaling of bewerking in het Hollandsch de voorkeur verdienen boven eene uitgave van den Mal. tekst. Eene eigenlijke vertaling zou echter, naar het mij voorkomt, minder doelmatig zijn. Maar door eene bewerking, waarbij alle onnoodige omhaal vermeden en toch niets wezenlijks achterwege gelaten wordt, zou de lezing van dit geschrift meer genietbaar en aangenamer kunnen 
worden voor belangstellenden. De ondergeteekende is bereid die bewerking op zich te nemen en stelt voor die in eene volgende aflevering der Bijdragen te plaatsen."

De Voorzitter zegt den Rapporteur dank voor zijn advies en stelt voor zijn aanbod aan te nemen.

Dienovereenkomstig wordt besloten.

Andermaal het woord nemende deelt het bestuurslid Niemann zijn gevoelen mede omtrent de in zijne handen gestelde bijdrage van dr. J. Groneman over Tjandi Parambanan op Midden-Java na de ontgraving. Hij acht haar alleszins belangrijk en zou gaarne tot eene uitgave daarvan vanwege het Instituut willen aanraden, vreesde hij niet, dat de kosten, verbonden aan de reproductie van het groot aantal bijgevoegde platen, de financieële draagkracht van het Instituut zouden te bovengaan, waarom hij voorstelt den Secretaris uit te neodigen omtrent die kosten informatiën in te winnen.

Dienovereenkomstig wordt besloten en mitsdien de beslissing der vraag omtrent de uitgave van dr. Groneman's bijdrage aangehouden.

Namens het lid C. M. Pleyte Wz., te Amsterdam, biedt de Secretaris, ter plaatsing in de Bijdragen, een opstel aan over de "plechtigheden en gebruiken uit den cyclus van het familieleven der volken van den Indischen Archipel ".

Om bericht en raad in handen gesteld van het bestuurslid Niemann.

Overeenkomstig de hem in de vorige vergadering gedane opdracht brengt de heer Kielstra rapport uit omtrent de uit de nalatenschap van den heer de Kock ontvangen schrifturen en zegt dat zij bestaan uit:

$1^{10}$. eene vertaling van de bekende maleische geschiedenis der prinses Djohor Manikam;

20. een op Palembangschen bodem geteeld verhaal, getrokken uit een Hikajat;

3o. eenige mededeelingen omtrent Siam omstreeks 1820, afkomstig van een Arabier die deel uitmaakte van het gevolg van eene derwaarts door den GG. van der Capellen gezonden Commissie;

4. . een fragment betreffende de, geheel op legenden berustende, oude geschiedenis van Palembang;

50. een handschrift, in 1829 te Decima opgesteld, betreffende "bijzonderheden omtrent Japan, opgegeven in schetsẹn over de zeden 
en gebruiken, meer bijzonder van de ingezetenen der stad Nagasakij". De steller, een vriend van de heeren Mr. J. H. Tobias en J. Tiedeman, aan wie hij zijn werk opdraagt, was waarschijnlijk destijds opperhoofd onzer vestiging te Decima.

6o. eene door den heer De Kock opgestelde, nagenoeg geheel op overleveringen berustende, "geschiedenis van het Rijk van Djambi" (1848).

Alleen het sub 50. genoemde handschrift komt den Rapporteur voor, eenige wetenschappelijke waarde te bezitten, Maar ook ten opzichte daarvan zal er wel geen sprake van zijn, op de eene of andere wijze tot geheele of gedeeltelijke publicatie over te gaan.

Rapporteur adviseert alzoo de genoemde stukken in de handschriftenverzameling van het Instituut te deponeeren.

Dienovereenkomstig wordt besloten, onder dankbetuiging voor 't uitgebracht rapport.

De Voorzitter, Penningmeester en Secretaris brengen achtereenvolgens rapport uit omtrent een aan het Instituut gedaan aanbod tot aankoop van een heerenhuis, toebehoorende aan wijlen den Graaf van Hogendorp, in de Lange Houtstraat. Hoewel het huis op zich zelf niet alleszins afkeurenswaardig is, zou echter een aankoop daarvan te bezwarend zijn; daar een som van $f 40.000$ daarvoor wordt gevraagd. Met het oog daarop meenden de Rapporteurs van verdere onderhandelingen te moeten afzien.

Staande de vergadering worden tevens ter tafel gebracht eenige ontwerpen betreffende eene mogelijke verbouwing van het tegenwoordige gebouw.

Met belangstelling neemt de vergadering van een en ander kennis en verklaart de Commissie te dezer zake diligent.

De Voorzitter oppert de vraag, of het geoorloofd zou zijn van de vergaderzaal van het Instituut gebruik te maken voor eene vergadering, die de heer van Deventer c.s. Zondag a.s. wenscht bijeen te roepen.

Gehoord de bezwaren van den Secretaris, wordt, na gedachtenwisseling, besloten, den heer van Deventer uit te noodigen de vergadering in de Instituutslocalen op een werkdag te willen uitschrijven.

Niets meer hierna aan de orde zijnde, wordt de vergadering door den Voorzitter gesloten. 


\section{6 sTE BESTUURSVERGADERING}

GEHOUDEN 21 NOVEMBER 1891.

Tegenwoordig de heeren der Kinderen (Voorzitter), N. P. van den Berg (Ondervoorzitter), L. W. C. van den Berg, Kielstra, Niemann, Quarles van Ufford, Schlegel, Vreede en Wijnmalen (Secretaris). Afwezig de heeren de Groot en van der Pant.

De notulen van het verhandelde in de vorige vergadering worden gelezen en goedgekeurd.

Mededeeling wordt gedaan van de sedert de vorige bijeenkomst ingekomen boekwerken en tijdschriften, terwijl ten geschenke ontvangen is van den heer Directeur van 's Rijks Ethnografisch Museum te Leiden een uittreksel van zijn jaarverslag, en van den heer J. D. E. Schmeltz een "Nachruf" ter nagedachtenis van wijlen het Bestuursiid Dr. G. A. Wilken, een "Separatabdruck aus Am Urquell, II no. 12 Red. Dr. Friedr. Krauss. Wien.

Plaatsing der boekwerken in de Bibliotheek, onder dankbetuiging aan de inzenders.

De Voorzitter deelt mede, dat zijn ingekomen:

10. circulaires van het Comité van organisatie van het Congrès international des Américanistes, dat van 1 tot 6 October 1892 te Huelva zal gehouden worden, benevens van het Comité tot organisatie van tentoonstellingen, die, gelijktijdig met evengenoemd Congres samenvallend, strekken ter viering van het vierde eeuwfeest van de ontdekking van Amerika.

Voor kennisgeving aangenomen.

2o. eene missive van de Redactie van den Staatsalmanak, ten geleide van eenige opgaven betreffende het Instituut voor dien A]manak bestemd, met verzoek, ze zoo noodig te wijzigen en daarna terug te zenden.

De Secretaris deelt mede, dat aan dit-verzoek bereids voldaan is.

3. een schrijgen van den Bibliothecaris van de Biblintheek van 
Teyler's Stichting, dd. 22 Oct. jl., houdende dankbetuiging voor de toezending der Bijdragen, $5^{\text {e }}$ R., dl. VI, $4^{\mathrm{e}}$ afl.

Aangenomen voor kennisgeving.

$5^{\circ}$. brieven van de medeleden W. W. Hunter en D. F. van der Pant, houdende bericht van hunne veranderde adressen.

Voor kennisgeving aangenomen.

$6^{\circ}$. een schrijven van den heer R. van Eck, waarbij, in antwoord op de tot hem gerichte noodiging tot eene critische bespreking van Brandstetter's jongste bijdrage over de Maleische letterkunde, wordt medegedeeld dat hij daaraan niet kan voldoen.

Aangenomen voor kennisgeving, terwijl, na eenige gedachtenwisseling wordt goedgekeurd, dat door een der Bestuursleden de bedoelde taak zal worden vervuld.

De Secretaris deelt mede, dat ter voldoening aan het besluit der Algemeene Vergadering van de jongste uitgave van des heeren J. L, van der Toorn's Minangkabausch-Maleisch-Nederlandsch Woordenboek, exemplaren voor de leden van het Instituut zijn verkrijgbaar gesteld voor de helft van den handelsprijs, dus à $f$ 4.-. De Secretaris doet voorlezing van de circulaire van den uitgever Martinus Nijhoff, waarbij hiervan den leden mededeeling wordt gedaan.

Aangenomen voor kennisgeving.

Ten vervolge op het schrijven van den Minister van Koloniën van 23 Juli 1890 , Lett. $\mathrm{A}^{1}, \mathrm{n}^{0} .26$ is, onder geleide eener missive van 7 November jl. Lett. $\mathrm{A}^{1}, \mathrm{n}^{0}$. 11, aan het Instituut toegezonden eene nota van den Controleur der Afdeeling Asahan, benevens een afschrift van de missive van den Controleur der onderafdeeling Laboean-Deli van 24. Juni jl. $\mathrm{n}^{\circ} .3 / 1$, betreffende het in hunne handen gesteld geschrift van wijlen den hoogleeraar Dr. G. A. Wilken, getiteld: "De verbreiding van het matriarchaat op Sumatra."

Aangehouden tot eene volgende vergadering.

De Secretaris brengt ter tafel een schrijven van den heer $\mathrm{H}$. Sundermann, missionaris op Nias, ten geleide van eenige reeds vroeger door hem ter plaatsing in het Tijdschrift van het Instituut toegezegde Niassische taal- en letterkundige bijdragen.

In handen gesteld van het bestuurslid Niemann. 5e Volgr. VII. 
Onder herinnering aan de bereids door de Tweede Kamer goedgekeurde en weldra definitief vast te stellen Begrooting voor Nederlandsch-Indië voor het dienstjaar 1892, bespreekt de Secretaris de vraag, of het niet raadzaam zou zijn, dat reeds nu vanwege het Instituut een adres aan den Gouverneur-Generaal van N. I. worde gericht, waarbij aan de Indische Regeering het verzoek wordt gedaan om aan het Instituut voor 1892 een subsidie toe te kennen van f 10,000 , welk bedrag op de begrooting voor NederlandschIndië voor wetenschappelijke onderzoekingen beschikbaar is gesteld: een en ander in aansluiting aan het van den Gouverneur-Generaal van N. I. ontvangen besluit van 16 Juni $1891, \mathrm{n}^{\circ} .23$.

$\mathrm{Na}$ eenige gedachtenwisseling wordt dienovereenkomstig besloten, waarna een concept-adres wordt voorgelezen en goedgekeurd van den volgenden inhoud:

No. 654 .

\section{Aan \\ Zïne Excellentie den Gouverneur-Generaal van Nederlandsch-Indiè.}

"Bij Uwer Excellentie's besluit van 16 Juni 1891, no. 23, werd aan het Koninklijk Instituut voor de taal-, land- en volkenkunde van Nederlandsch-Indië, te 's Gravenhage gevestigd, voor het loopend dienstjaar 1891 eene subsidie toegekend van $f 5000$ (vijf duizend gulden), om met behulp van dat bedrag een wetenschappelijk onderzoek van de eilanden der Banda-zee in te stellen.

"Gelijk Uwer Excellentie bekend zal zijn, is bereids met dat onderzoek een aanvang gemaakt door den hoogleeraar K. Martin, die zich voorstelt gedurende het volgende jaar zijne omvangrijke taak voort te zetten, zoo mogelijk met en in vereeniging met een anderen geleerde, met wien het Instituut in onderhandeling is getreden ter vervanging van wijlen den hoogleeraar Dr. G. A. Wilken, wien aanvankelijk door het Instituut het bovenomschreven onderzoek was opgedragen.

"Tot voortzetting van dat onderzoek zou het Instituut zich gaarne in staat gesteld zien door den ontvangst eener nadere subsidie van $f 10,000$, zijnde het bedrag dat voor wetenschappelijke onderzoekingen in het tweede Hoofdstuk der Begrooting van NederlandschIndië voor 1892 opnieuw beschikbaar is gesteld.

"Het Koninklijk Instituut houdt zich overtuigd, dat zijn verzoek bij Uwe Excellentie geen bezwaar zal ontmoeten, waar bereids in 
Haar bovenvermeld besluit was te kennen gegeven. dat verzoeken om nadere subsidies ter voorzetting van het meergemeld onderzoek in 1892 en 1893 in gunstige overweging zouden worden genomen, ingeval de begrootingen dier jaren daartoe gelegenheid mochten geven.

"Waar eerlang de vaststelling en afkondiging der Begrooting van Nederlandsch-Indië voor 1892 , waarin de boven omselreven post voorkomt, kan worden tegemoetgezien, neemt het Koninklijk Institunt de vrijheid zich tot Uwe Exeellentie te wenden met het eerbiedig verzoek dat het Haar moge behagen aan het Instituut voor het dienstjaar 1892 het voor wetenschappelijke onderzoekingen beschikbaar gestelde bedrag van $f 10,000$ als subsidie toe te kennen.

"En mocht Uwe Fxcellentie die subsidie toekennen, zij gelieve Hare gunstige beschikking langs telegrafischen weg door tusschenkomst van het Departement van Koloniën aan het Instituut te willen mededeelen, en tevens, ter voorkoming van oponthoud van het onderzoek, het geldelijk bedrag beschikbaar te stellen aan 's Lands kas te Amboina ter rechtstreeksche uitkeering aan den hoogleeraar Dr. K. Martin of diens gemachtigde aldaar, onder gehoudenheid van nadere verantwoording der hem toegekende gelden aan het Koninklijk Instituut.

't Welk doende, enz."

Met het oog op eenige vergaderingen, die de heer van Deventer c. s. zich voorstelt bijeen te roepen ter bespreking van het voorgenomen plan eener uitgave van een Woordenboek van Ned.-Indië, geeft de Voorzitter in overweging aan evengemeld correspondeerend Lid de door hem gevraagde vergunning, tot wederopzeggens, te verleenen tot het houden dier bijeenkomsten in het lokaal van het Instituut.

$\mathrm{Na}$ eenige gedachtenwisseling wordt dienovereenkomstig besloten.

De Secretaris deelt mede, dat bij hem vanwege het Bestnur van het Indisch Genootschap is geklaagd over onvoldoend licht ter gelegenheid der algemeene vergaderingen dier Instelling. Bij onderzoek schijńt de oorzaak daarvan te liggen dat de aanwezige lichtmeter te zwak is, waarom, namens den Penningmeester, het voorstel wordt gedaan den anwezigen meter door een 10 , dan wel 20 lichtmeter te doen vervangen. Dienovereenkomstig wordt besloten.

Namens den Penningmeester biedt de Secretaris aan de vergadering 
de begrooting aan voor het dienstjaar 1892. In rondlezing bij de Bestuursleden.

De heer Schlegel brengt rapport uit omtrent een aan het Instituut aangeboden handschrift over Japan, waaromtrent in de vorige vergadering bereids door het lid Kielstra eenige mededeeling is gedaan. Den Rapporteur is de schrijver van het handschrift onbekend, doch zijne beschrijving van de Japansche toestanden is niet onbelangrijk te achten, waarom het der moeite waard zou zijn haar te zijner tijd in het tijdschrift van het Instituut uit te geven.

$\mathrm{Na}$ eenige gedachtenwisseling vereenigt de vergadering zich met dit advies, waarvoor de Voorzitter den heer Schlegel dank zegt, waarna, niets meer aan de orde zijnde, de vergadering wordt gesloten.

\section{7sTE BESTUURSVERGADERING,}

GEHOUDEN 19 DECEMBER 1891.

Tegenwoordig de heeren der Kinderen (Voorzitter), J. H. de Groot (Penningmeester), L. W. C. van den Berg, Niemann, Quarles van Ufford, Schlegel, Vreede en Wijnmalen (Secretaris). Afwezig, met kennisgeving, de heeren N. P. van den Berg, Kielstra en van der Pant.

De notulen van het verhandelde in de vorige vergadering worden gelezen en goedgekeurd.

Door den Secretaris wordt mededeeling gedaan van de ingekomen boekwerken, waaronder van de heeren Pleyte, Quarles van Ufford en van der Lith opstellen gewijd aan de nagedachtenis van wijlen het Bestuurslid Wilken; voorts nog, ten vervolge op vorige zendingen, van den hoogleeraar mr. G. A. van der Lith, te Leiden, een exemplaar der aan de Leidsche Universiteit verdedigde dissertatie van den heer van Panhuys over Uitlevering; en van den Uitgever A. Harleben, te Weenen, een exemplaar van de "Praktische Grammatik des Malayischen Sprache nebst einem Lesebuche, sowie einem malayisch-deutschen und deutsch-malayischen Wörterbuche. Von H. Seidel." 
Plaatsing der werken in de bibliotheek, onder dankbetuiging aan de inzenders.

Verder zijn ingekomen missives:

$1^{\circ}$. van de Smithsonian Institution, te Washington, U. S. A. houdende dankbetuiging voor den ontvangst van het toegezonden $5^{\mathrm{e}}$ deel, 1890 , der Bijdragen van het Instituut.

2o. van Z. H. Prins Roland Bonaparte, te Parijs, van 8 December 1891, houdende dankbetuiging voor zijne benoeming tot afgevaardigde bij het in Augustus 1l. te Bern gehouden Internationaal geographisch Congres.

$3^{\circ}$. van den Hoofdagent der Koninklijke Paketvaart-Maatschappij, te Batavia, 29 October 1891, den ontvangst erkennende van het dezerzijdsch schrijven van 4 September ll. $\mathrm{n}^{\circ}$. 635 , in beleefd antwoord waarop wordt medegedeeld, dat Dr. Martin zich reeds schriftelijk tot hem had gewend ten einde eenige inlichtingen betreffende de reis naar Amboina te verkrijgen, welke hem onmiddellijk zijn verstrekt. Terwijl het door Z.H.Gel. aangekondigd bezoek wordt tegemoetgezien, zal gaarne worden voldaan aan het verzoek om Z.H.Gel., waar zulks mogelijk is, met raad en hulp te dienen en daardoor tot 't slagen van zijn voorgenomen onderzoek mede te werken.

$4^{0}$. van de heeren J. C. Jansen en C. Lely, Ministers van Marine en van Waterstaat, Handel en Nijverheid te 's Gravenhage, en G. de Waal, Ambtenaar bij het B. B. op Java, te Soekaboemi, allen houdende bericht van de aanvaarding hunner benoeming tot leden van het Instituut.

$5^{\circ}$. enz.

$6^{\circ}$. enz.

7\%. van den heer D. Heyting, oud-resident van Amboina, kennis gevende dat hij sedert medio October zijne woonplaats te 's Gravenhage gevestigd heeft.

Al deze missives, sub $1^{\circ} .-7^{\circ}$. vermeld, worden voor kennisgeving aangenomen.

Tot leden van het Instituut worden voorgedragen en benoemd 
de heeren mr. D. W. K. de Roo de la Faille, rechterlijk Ambtenaar te Batavia, G. de Roo de la Faille, aspirant-controleur te Tjitjalengka (Preanger-Regentschappen) en C. J. Westenberg, controleur op Sumatra.

Wordt voorgelezen een schrijven van de Berliner Gesellschaft für Anthropologie, Ethnologie und Urgeschickte, te Berlijn, van den $11^{\text {en }}$ December 1891 , waarbij het verzoek wordt gedaan tot ruiling der Bijdragen van het Instituut met het vanwege het genootschap uitgegeven Zeitschrift für Ethmologie.

Overeenkomstig het advies van den Secretaris wordt besloten aan het verzoek te voldoen.

Door het Beatuurslid Niemann wordt rapport uitgebracht omtrent de in zijne handen gestelde bijdrage des heeren C. M. Pleyte Wrn. Hulde brengende aan de zorg, waarmede het opstel is bewerkt, stelt hij voor het in een der eerstvolgende afleveringen der Bijdragen op te nemen, mits echter de schrijver vooraf zijn stuk bekorte en die wijzigingen daarin aanbrenge, welke hem, rapporteur, in het belang van het opstel noodig voorkomen en waarover hij zelf met den schrijver in briefwisseling hoopt te treden.

$\mathrm{Na}$ eenige gedachtenwisseling vereenigt de vergadering zich met dit advies.

In de tweede plaats brengt het bestuurslid Niemann rapport uit over de mede in zijne handen gestelde stukken betreffende de Niassische taal en letterkunde, door den missionaris Sundermann ter uitgave aangeboden. Onder herinnering aan hetgeen bij de eerste aanbieding dier stukken daaromtrent werd gerapporteerd en beslist, deelt de heer Niemann mede, dat een onderzoek van hetgeen nu opnieuw is aangeboden, hem vrijheid geeft den raad te geven het vanwege het Instituut in de Bijdragen uit te geven, wanneer de schrijver bereid is daarin nog eenige wijzigingen te brengen en alsnog eenige mededeelingen daarbij te voegen omtrent de wijze van spelling, terwijl hij zich bereid verklaart omtrent een en ander zelf met den auteur in briefwisseling te treden.

Onder dankbetuiging voor het uitgebracht rapport, vereenigt de vergadering zich daarmede eenparig.

Eindelijk brengt het bestuurslid Niemann een opstel ter tafel 
over den godsdienstige begrippen der Karo-Battaks van den Controlear C. J. Westenberg, hem door tusschenkomst van het medelid van Rijn van Alkemade aangeboden. Wordt goedgekeurd, dat daarover in de volgende vergadering verslag zal worden uitgebracht.

De Secretaris herinnert dat indertijd, op voorstel van wijlen den hoogleeraar Wilken, naar aanleiding van een door het Bestuur van het Instituut gedaan verzoek, door den Minister van Koloniën van de verhandeling over de "verbreiding van het matriarchaat op Sumatra" een aantal exemplaren naar Indië zijn gezonden, ter uitreiking aan de ambtenaren op Sumatra, met uitnoodiging onderzoekingen in te stellen, ten einde de bestaande leemten aan te vullen. Tengevolge dezer uitnoodiging werden omtrent dit onderwerp door eenige Ambtenaren bij het binnenlandsch bestuur op Sumatra eenige nota's samengesteld, welke door het Indisch Bestuur aan het Ministerie ran Koloniën zijn toegezonden, door welks tusschenkomst ze achtereenvolgend ter beschikking zijn gesteld van het Bestuur van het Instituut. Wijlen de hoogleeraar Wilken had daarvan, doch, slechts voor een gedeelte, gebraik gemaakt: getuige zijn nader in de Bijdragen, $5^{\mathrm{e}} \mathrm{R} .6^{\mathrm{e}} \mathrm{dl}$. opgenomen opstel "over het huwelijks- en erfrecht bij de volken van Zuid-Sumatra."

De Secretaris doet thans de vraag, welk gebruik er verder van de ingekomen nota's moet worden gemaakt, in verband met den herhaaldelijk vanwege het Departement van Koloniën kenbaar gemaakten wensch om ze, na gebruik, weder te mogen terug ontvangen.

$\mathrm{Na}$ eenige gedachtenwisseling wordt besloten de verschillende stukken, om bericht en raad, in handen te stellen van het bestuurslid, Prof. I. W. C. van den Berg.

Ingevolge eene hem gedane opdracht geeft de. Secretaris eene gedétailleerde opgave van de kosten der reproductie van de 64 totografieën van de Tjandi Prambanan op Midden-Java met den daarbij behoorenden tekst van Dr. J. Groneman. Daar uit den aard der zaak slechts betrekkelijk weinig exemplaren zullen worden verkocht, zouden de aanzienlijke kosten, die de uitgave zou vorderen, de draagkracht van het Instituut verre overschrijden, waarom in overweging wordt gegeven zich tot het Ministerie van Koloniën te wenden met het verzoek de uitgave met eene subsidie te willen steunen, waartegen zich het Instituut zijnerzijds zou verbinden 50 exemplaren beschikbaar te stellen. 
Na dankzegging an des Secretaris voor zijne opgaven, wordt, na eenige gedachtenwisseling, besloten vóor alles te trachten de voorgestelde subsidie te verkrijgen, en zich daartoe tot den Minister van Koloniën te wenden bij een adres, waarvan de samenstelling aan den Voorzitter en Secretaris wordt opgedragen.

Ter tafel wordt gebracht de begrooting voor het dienstjaar 1892 , welke bereids bij al de Bestuursleden in rondlezing is geweest. De Penningmeester licht haar nader toe, waarna de ingediende begrooting onveranderd, zonder hoofdelijke stemming, wordt aangenomen, onder dankbetuiging aan den Penningmeester voor de zorg daaraan besteed.

Overeenkomstig zijn voorstel wordt voorts goedgekeurd het afloopend contract met de brandassurantie-maatschappij "La Belgique" niet te continueeren, doch een nieuw contract te sluiten met de Maatschappij "Urania" te Amsterdam. Tevens wordt besloten het bedrag, waarvoor het meubilair van den Concierge wordt verzekerd, overeenkomstig diens verzoek te bepalen op $f$ 1000.-

Niets meer hierna aan de orde zijnde, wordt de vergadering door den Voorzitter gesloten.

\section{8sTE BESTUURSVERGADERING}

GEHOUDEN 16 JaNUARI 1892.

Tegenwoordig de hh. der Kinderen (Voorzitter), J. H. de Groot (Penningmeester), mr. L. W. C. van den Berg, Kielstra, Niemann, Schlegel en Wijnmalen (Secretaris). Afwezig de hh. N. P. van den Berg, van der Pant, Quarles van Ufford en Vreede.

De notulen van het verhandelde in de vorige vergadering worden voorgelezen, en, eenigszins gewijzigd, goedgekeurd.

De Voorzitter deelt mede, dat ingekomen is een bericht van de hh. N. P. van den Berg en Treede, dat zij, de eerste wegens ambts- 
bezigheden, de tweede wegens lichte ongesteldheid de vergadering niet kunnen bijwonen.

Verder zijn ingekomen missives:

$1^{\circ}$. van het Bestuur van de Maatschappij der Nederlandsche Letterkunde te Leiden, ten geleide van een exemplaar der Handelingen en Levensberichten, 1891.

2o. van den heer L. M. Vonck, Controleur der Moesi Ilir, houdende aanbieding eener door hem samengestelde nota over de Benzoëcultuur in de residentie Palembang, opgenomen in en overgedrukt uit het Tijdschrift, Orgaan der Nederlandsche Maatschappij ter bevordering van Nijverheid, September 1891.

Plaatsing der geschriften in de bibliotheek, onder dankbetuiging aan de Inzenders.

Ter tafel wordt gebracht een circulaire houdende mededeelingen over en uituoodiging tot het zenden van afgevaardigden naar het 10e Internationaal Orientalisten Congres, dat in September-October 1892 te Sevilla zal gehouden worden. Wordt besloten de behandeling dezer zak aan te houden tot de Bestuursvergadering in Juni a. s, doch inmiddels aan het Uitvoerend Comité mede te deelen, dat het Instituut als lid van het Congres kan worden ingeschreven voor 12 francs, in steê van 20 francs, gelijk verkeerdelijk wordt opgegeven in de circulaire, wasrvan de hoogleeraar Schlegel enkele exemplaren ter beschikking stelt voor belangstellenden.

Van de Royal Geographiral Society te Londen is een schrijven ontvangen houdende een voorstel omtrent de spelling van platsnamen. $\mathrm{Om}$ bericht en raad in handen gesteld van het bestuurslid Niemann.

De Voorzitter deelt mede, dat verder zijn ingekomen:

10. enz.

$2^{\circ}$. een schrijven van den heer Egter van Wissekerke, waarbij namens Mevrouw de Wed. M. A. van Walcheren kennis wordt gegeven van het overlijden van haar Echtgenoot, met verzoek zijn naam van de ledenlijst van het Instituut te willen afvoeren.

3。. een schrijven van den heer Twiss, uit Loeboeh Basoeng, houdende mededeeling dat hij in het laatst der maand Februari of 
begin van Maart naar Nederland denkt te vertrekken, waarom hij verzoekt de voor hem bestemde uitgaven van het Instituut niet meer naar Indië te willen zenden, doch te bezorgen aan het adres van den heer W. Twiss, te 's Gravenhage (Denneweg 58).

$4^{\circ}$. een schrijven van den heer Ch. van Kerckhoff, houdende mededeeling, dat de voor hem bestemde geschriften voorloopig naar Buitenzorg (Hôtel Chemin de fer) moeten worden geadresseerd.

Van het in de missives sub $2^{\circ}-4^{\circ}$ vermelde zal aanteekening worden gehouden.

$5^{\circ}$. een schrijven van den heer Dr. J. Brandes, Commissaris van het Instituut, waarbij wordt medegedeeld dat aan den heer J. Kreemer, die sinds geruimen tijd geen edita van het Instituut ontvangen heeft, ze voor zoover ze voorhanden waren zijn verstrekt.

De Secretaris deelt mede, dat de heer Kreemer reeds tijdens zijn verblijf hier te lande voor het lidmaatschap heeft bedankt, waarom hij niet op de ledenlijst vermeld staat. Hiervan zal den heer Brandes mededeeling worden gedaan.

$6^{\circ}$. een schrijven van den heer Van Hasselt, te Padang-Sidempoean, houdende kennisgeving dat de heer W. D. Helderman, Controleur bij het Binnenlandsch Bestuur te Batang Toroe, residentie Tapanoeli, het verzoek heeft gedaan met $1^{\circ}$ Januari 1892 als lid van het Instituut te mogen worden aangenomen, waarvan aan HH. Commissarissen te Batavia mededeeling is gedaan.

Wordt besloten aan het verzoek te voldoen.

$7^{\circ}$. een schrijven van Commissarissen van 17 November 1891 , waarbij $a$. wordt toegezonden een prima-wissel, groot $f 399 ; b$. eene zoo nauwkeurig mogelijk bijgewerkte naamlijst der in NederlandschIndië aanwezige leden van het Instituut, onder mededeeling, dat van sommige ambtenaren op non-activiteit de tegenwoordige verblijfplaats niet bekend is, terwijl zij, achter wier namen een teeken in rooden inkt is geplaatst, het verzoek hebben gedaan met $1^{\circ} \mathrm{Ja}$ nuari 1892 als lid van het Instituut te mogen worden aangenomen.

Aan Commissarissen zal de ontvangst van den wissel worden erkend, die bereids aan den Penningmeester is ter hand gesteld, terwijl de namen der voorgestelde nieuwe leden op de lijst voor de Algemeene Vergadering zullen worden gebracht. 
8. een schrijven van den heer G. W. W. E. Baron van Hoëvell, Resident van Amboina, 7 November 1891, houdende bereidverklaring om den hoogleeraar Dr. K. Martin bij zijn geognostisch onderzoek van de eilanden der Banda-zee zooveel mogelijk behulpzaam te zijn, hoewel die hulp zich hoofdzakelijk zal moeten bepalen tot moreelen steun, daar geognostische studiën geheel buiten den kring van de onderzoekingen des briefschrijvers vallen.

Aangenomen voor kennisgeving.

Naar aanleiding van dit schrijven des heeren van Hoëvell deelt de Secretaris mede dat hij een particulieren brief, ged. Amboina 28 Nov. 1891, heeft ontvangen van den hoogleeraar Martin, waaruit bleek, dat hij juist een dag vóór de dagteekening van zijn brief in Amboina was aangekomen, na te Batavia en te Buitenzorg een tiental dagen verblijf te hebben gehouden om de noodige bezoeken bij de verschillende autoriteiten af te leggen, bij welke gelegenheid de overtuiging werd verkregen, dat naar alle waarschijnlijkheid de voor het verder onderzoek nog benoodigde gelden zeker wel beschikbaar zullen worden gesteld, terwijl het aan twijfel onderhevig is of ook voor het ethnologisch onderzoek de noodige materiëele steun zal worden verkregen, daar men na het overlijden van den hoogleeraar Wilken andere plannen anhangig schijnt te willen maken.

Onder weg had Dr. Martin nog al een en ander kunnen verzamelen, door zooveel mogelijk partij te trekken van de plaatsen, die door de boot werden aangedaan; vooral uit de Minahassa schijnt de hoogleeraar een rijk materiaal van onderzoek te hebben verzameld en verder van ongeveer alle eilanden, die hij bezocht. Eenigszins vermoeid was hij te Amboina aangekomen, waar hij echter den resident van Hoëvell, die op eene dienstreis was, nog niet ontmoette, terwijl het zijn voornemen was met het onderzoek van Amboina te beginnen door eerst langs de baai tochten te maken en alsdan door het eiland heen te trekken; het vertrek naar Ceram en Boeroe zal echter van omstandigheden afhangen.

De Voorzitter zegt den Secretaris dank voor de door hem van den heer Martin ontvangen mededeelingen.

De heer Niemann brengt nader verslag uit omtrent de bijdragen der heeren Pleyte en Sundermann, waaromtrent hem opgedragen was nader met die schrijvers in overleg te treden. Aan de gemaakte 
bedenkingen is door beiden tegemoetgekomen, waarom hij in overweging geeft de beide stukken ter opneming aan de Redactie van de Bijdragen toe te vertrouwen.

Dienovereenkomstig wordt besloten.

De heer Niemann het woord hernemend, deelt mede, overeenkomstig zijne in de vorige vergadering gedane toezegging, het opstel van den Controleur Westenberg over de godsdienstige begrippen der Karo-Bataks te hebben nagegaan en adviseert tot plaatsing daarvan in de Bijdragen, terwijl den schrijver zou kunnen bericht worden, dat het Bestuur er prijs op zou stellen mededeelingen te ontvangen omtrent de literatuur, kleeding, huisraad en andere ethnografische bizonderheden, vooral bij de onafhankelijke Karo-Bataks.

Onder dankbetuiging aan den Rapporteur wordt overeenkomstig zijn advies besloten.

Door het bestuurslid L. W. C. van den Berg wordt het volgend rapport uitgebracht:

"In de Bestuursvergadering van 21 Januari 1888 (Not. p. XLIV) werd besloten om van het opstel van nu wijlen den heer G. A. Wilken, getiteld: "De verbreiding van het Matriarchaat op Sumatra" (zie Bijdragen $5^{\mathrm{e}}$ Reeks dl. III p. 163 en vv.) een zeker aantal overdrukken te doen toekomen aan eenige op Sumatra geplaatste ambtenaren van het Binnenlandsch Bestuur, met verzoek om aanvulling en zoo noodig verbetering van hetgeen in bedoeld opstel werd medegedeeld. De tusschenkomst van het Departement van Koloniën werd daartoe ingeroepen, en blijkens de missive van den toenmaligen Minister dd. 25 Sept. 1888 Litt A' No. 21 (Not. 20/10 - 88- p. XXXVII) welwillend verleend.

"Als eerste gevolg van dezen maatregel ontving het Instituut bij missive van den Min. v. Koloniën dd. 27 Juli 1889 Litt A' No. 14. (Not. 28/9 -89- p. XXIX) eene nota van wijlen den Controleur A. F. P. Graafland over de verbreiding van het Matriarchaat in het landschap Indragiri, welke nota, op advies van den heer Wilken, na bekomen machtiging van den Minister, in de Bijdragen werd opgenomen (Not. 26/10 - 89- p. XXXIV, en 16/11 -89- p. XL; Bijdr. 5e Reeks, dl. V p. 40 en vv.) De missive, waarbij de machtiging werd verleend, was van 8 Nov. 1889 Litt. A $\mathrm{N}^{\circ}$. 8. Ik vermeld dit, omdat op twee plaatsen in de Notulen de datums door een drukfout minder juist is aangegeven, en de 
Minister in een volgenden brief naar deze missive verwijst. (Zie Not. p. XL en LXXXIII). Er zoude dus allicht misverstand kunnen ontstaan.

"Achtereenvolgens werden later door het Instituut ontvangen de missives van den Minister van Koloniën :

$1^{\circ}$. dd. 20 December 1889 Litt. A' $\mathrm{N}^{\circ}$. 15 houdende aanbieding der berichten van de Assistent-Residenten van Priaman en van Ajerbangis en Rau, en van eene nota van den zendeling J. H. Meerwaldt, van welke laatste nota de Resident van Tapanoeli, de heer A. L. van Hasselt, de opname in de Bijdragen aanbeveelt.

$2^{\circ}$. dd. 24 Februari 1890 Litt. A' $N^{\circ}$. 10 houdende aanbieding der berichten van de Controleurs van Ogan Oeloe en Enim (Komering Oeloe) en van de Ranau-Districten.

3o. dd. 21 Maart 1890 Litt. A $\mathbf{1}^{\circ} \mathrm{N}^{\circ} .11$ houdende aanbieding der berichten van de Controleurs van Padang Lawas, Toba, I Lematang Oeloe, Moesi Ilir, Lematang Ilir, Rawas en Kikim en van den Assistent-Resident van Lahat.

$4^{\circ}$. dd. 29 April 1890 Litt. A', No. 11 houdende aanbieding der berichten van den Assistent-Resident van Tanah-Datar en van de Controleurs der Pasemah-landen en van Pangkalan en Kampar.

$5^{\circ}$. dd. 23 Juli 1890 Litt. A' $\mathrm{N}^{\circ}$. 26 houdende aanbieding der berichten van den Controleur van Bengkalis.

$6^{\circ}$. dd. 7 November 1891 Litt. $\mathrm{A}^{\mathbf{1}}, \mathrm{N}^{\circ}$. 11 houdende aanbieding der berichten van de Controleurs van Asahan en Laboean Deli.

Allen handelende over het Matriarchaat op Sumatra. De missives 1-4 zijn verhandeld in de Not. van 18-10-90 p. LXXXIII, 19-4-90 p. CV en $17-5-90$ p. CXIV. De beide laatstgenoemde missives staan nog niet in de gedrukte Notulen vermeld. Van de berichten uit Ogan Oeloe en Komering Oeloe, de Ranau-Districten, LematangOeloe, Moesi-Ilir, Lematang Ilir (Semendo), Rawas, Kikim, Lahat en de Pasemah-Landen werd reeds door den heer Wilken zelven het noodige gebruik gemaakt voor zijn opstel over het huwelijks- en erfrecht bij de volken van Zuid-Sumatra, opgenomen in de Bijdragen

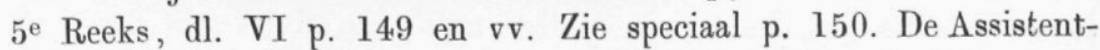
Residenten van Priaman en van Ajerbangis en Rau berichten niet anders dan dat hetgeen in het opstel van den heer Wilken voorkomt, wat de feiten betreft, ten aanzien van hunne afdeelingen juist is. De heer Meerwaldt, ofschoon de juistheid der door den heer Wilken omtrent de Bataks medegedeelde feiten erkennende, betoogt echter dat de conclusie, door ons overleden bestuurslid uit 
die feiten getrokken, omtrent een vroeger bij dat volk bestaan hebbend Matriarchaat, ongegrond is, en vermeent dat bedoelde feiten meer natuurlijk langs anderen weg kunnen worden verklaard. Met den heer van Hasselt ben ik van oordeel, dat dit stuk in de Bijdragen kan worden opgenomen, behoudens hier en daar eene geringe wijziging in taal en redactie, welke de schrijver zelf, indien hij de drukproeven corrigeerde, zoude hebben aangebracht. De Controleur van Toba verklaart zich met de conclusie van den heer Meerwaldt te vereenigen.

"Wat de overige stukken betreft, onderscheidene daarvan bevatten zeer belangrijke aanvullingen en verbeteringen op het meergenoemd opstel van den heer Wilken; maar geen enkel is m. i. op zich zelf, gelijk het daar ligt, voor publiceering geschikt. De meeste schrijvers doen trouwens zelven uitkomen, dat zij slechts bouwstoffen hebben willen leveren, en geen hunner heeft blijkbaar er aan gedacht zijn arbeid voor de pers te bestemmen. Van velen zijn de berichten in den vorm van losse aanteekeningen gegeven en zouden dus om die reden alléen voor een afzonderlijke uitgave ongeschikt zijn.

"Op grond van het bovenstaande heb ik de eer te adviseeren het opstel van den heer Meerwaldt te platsen en de overige stukken onder dankbetuiging aan het Departement van Koloniën terug aan te bieden".

De Voorzitter dankt den heer van den Berg voor zijn rapport en stelt voor zich met de conclusie daarvan te vereenigen.

Dienovereenkomstig wordt besloten.

De Secretaris stelt voor de volgende Bestuurs- en Algemeene Vergaderingen te houden op den derden en vierden Zaterdag der maand Februari a. s., en vraagt tevens machtiging als punten van behandeling voor de Algemeene Vergadering op het convocatie-biljet op te nemen: het verslag van den Secretaris over 1891; de rekening en verantwoording van den Penningmeester over hetzelfde tijdvak; de verkiezing van drie Bestuursleden in de plaats van nu wijlen Dr. G. A. Wilken en de hh. de Groot en Wijnmalen; het voorstel om met opzicht tot de voorgenomen uitgave van het werk van Dr. J. Groneman gebruik te maken van al. 2 van art. 13 van het Reglement; voorts het voorstel om in art. 6 van het Reglement eene 4 e alinea toe te voegen, ter bepaling, dat wie ophouden wil lid te zijn, verplicht zal zijn daarvan kennis te geven vóór den aanvang van 
het jaar; en eindelijk der vergadering mededeeling te doen van de benoeming van nieuwe leden.

Eenparig vereenigt de vergadering zich met dit voorstel.

In verband met de omstandigheid dat weldra aan een aantal nieuw te benoemen leden exemplaren van het Reglement zullen moeten worden uitgereikt, stelt de Secretaris met het oog op den geringen voorraad, welke daarvan aanwezig is, voor om een herdruk daarvan te mogen doen bezorgen tot een getal van 500 exemplaren. Dienovereenkomstig wordt zonder beraadslaging besloten.

De Penningmeester legt over de rekening en verantwoording over 1891, waaruit hị tevens de voornaamste cijfers mededeelt. In handen gesteld van de heeren Kielstra en Wijnmalen met verzoek daaromtrent in de volgende vergadering verslag uit te brengen, terwijl tevens wordt besloten de hh. Canne en Mr. C. Voute en, bij ontstentenis van een van beiden, den heer van Meeteren Brouwer uit te noodigen de rekening na te zien en daaromtrent der Algemeene Vergadering te willen dienen van bericht en raad.

Namens het Eerelid, Dr. Kern, deelt het bestuurslid Schlegel mede dat door hem eene taalkundige bijdrage over het Sawuneesch is gereed gemaakt, waarvoor eene plaatsing wordt gev raagd, het eerste gedeelte in de April- en het slot in de Juli-aflevering der Bijdragen.

In verband hiermede wordt de inhoud der April-aflevering der Bijdragen besproken en wordt de Secretaris gemachtigd daarvoor te bestemmen de door den hoogleeraar Kern samengestelde studie, benevens, zoo mogelijk althans, geheel of gedeeltelijk, de bijdragen der heeren Sundermann, Meerwaldt, Kielstra, Westenberg en Niemann.

Naar aanleiding van ontvangen klachten omtrent de te late bezorging van de verschijnende afleveringen der Bijdragen, waarbij opnieuw eenerzijds de verzending per post wordt aanbevolen, anderzijds ontraden, wordt, gehoord de inlichtingen van den Secretaris, die daaromtrent een schrijven van de firma Smits mededeelt, besloten om van de verzending per post gebruik te maken, voor zoover het exemplaren betreft, bestemd voor de Eereleden, correspondeerende en oud-bestuursleden.

Niets meer hierna aan de orde zijnde, wordt de vergadering door den Voorzitter gesloten. 


\section{9sTE BESTUURSVERGADERTNG,}

GEHOUdEN 20 FEBRUARI 1892.

Tegenwoordig de hh. der Kinderen (Voorzitter), de Groot (Penningmeester), L. W. C. van den Berg, Kielstra, Niemann, Quarles van Ufford, Schlegel, Vreede en Wijnmalen (Secretaris). Afwezig, met kennisgeving, de hh. N. P. van den Berg en van der Pant.

De notulen van het verhandelde in de vorige vergadering worden gelezen en, eenigzins gewijzigd, goedgekeurd, waarna de aandacht wordt gevestigd op de ontvangen en aangekochte boekwerken, waarmede de bibliotheek is verrijkt geworden.

De voorzitter deelt vervolgens den ontvangst mede van

$1^{\circ}$. eene misseve van de Directie der Société Impériale Russe de géographie te St. Petersburg, houdende kennisgeving van het overlijden van haren President, Zijne K. H. den Grootvorst Constantijn Nicolayevitch.

$2^{\circ}$. eene missive van de Académie Royale des Sciences de Lisbonne, waarbij, onder dankbetuiging, de ontvangst wordt erkend van de toegezonden Bijdragen 1891, Ve Volgr. VI. 3.

$3^{\circ}$. eene missive van den Conservator van de Bibliotheek van Teyler's Stichting, te Haarlem, houdende aankondiging van den ontvangst van de $l^{\mathrm{e}}$ afl. van dl. VII der Bijdragen.

$4^{\circ}$. eenige circulaires, houdende mededeelingen omtrent het te houden internationaal congres der Amerikanisten en de te houden tentoonstellingen ter gelegenheid der viering van het $4^{\mathrm{e}}$ eeuwfeest der ontdekking van Amerika.

$5^{\circ}$. een schrijven van den heer J. van Dissel, te Delft, houdende kennisgeving van het overlijden van het medelid S. van Dissel, Oud-Inspecteur van het Inlandsch Onderwijs, te 's Gravenhage. 
$6^{\circ}$. een schrijven van het lid M. van der Ent, waarbij, onder mededeeling van zijn aaustaand vertrek naar Indië, opgave wordt gedaan van zijn voorloopig adres.

7\%. een schrijven van het lid H. Spakler, Consul der Nederlanden te Djeddah, houdende verzoek om, met 't oog op zijn aanstaand vertrek naar Nederland, de voor hem bestemde stukken van het Instituut voorloopig te willen zenden aan het adres des heeren $J$. C. Spakler, Prinsengracht 530, Amsterdam.

$8^{\circ}$. enz.

A] deze missives, sub $1^{\circ}-8^{\circ}$ vermeld, worden voor keunisgeving aangenomen.

Ter tafel wordt gebracht een schrijven van Commissarissen van 15 Januari jl., benevens een aantal briefkaarten. Commissarissen bieden aan een prima wissel groot $f 399 \mathrm{~N}$. C., betaalbaar als gebruikelijk, onder aanteekening dat nieuwe geldverzendingen spoedig zullen volgen, terwijl met de laatste verzending ook de verantwoordingen over 1890 en 1891 zullen medegaan. Voorts wordt opgave gedaan van de namen zoowel van hen, die voor het lidmaatschap bedankt hebben als van hen, die wenschen als leden toe te treden, terwijl tevens bericht wordt aan welke, leden enkele hun ontbrekende afleveringen der Bijdragen op hunne aanvrage is uitgereikt geworden.

Wordt besloten den wissel in handen te stellen van den Penningmeester, terwijl de Secretaris gemachtigd wordt den ontvangst daarvan te erkennen en, voor zooveel noodig, aanteekeningen te houden van de namen der van de lijst af te voeren en van die der nieuwe leden.

De Secretaris deelt mede, juist even vóór den aanvang der vergadering, een schrijven te hebben ontvangen van den heer Sundermann, waarbij hem nog eenige stukken worden toegezonden ter toevoeging aan die, waarvan de uitgave vanwege het Instituut wordt voorbereid. Met het oog op het spoedeischende der zaak, daar de vroeger door den heer Sundermann aangeboden stukken bereids ter perse zijn, stelt de Secretaris voor, hem te machtigen de nu ontvangen nadere stukken in handen te stellen van het bestuurslid Niemann, en na gehouden 5e Volgr. VII. 
overleg omtrent het al dan niet uitgeven dier stukken eene beslissing te nemen.

Dienovereenkomstig wordt besloten.

Omtrent het in de vorige bijeenkomst in zijne handen gesteld schrịjven van de Royal Geographical Society betreffende de schrijfwijze van geographische namen door Engelschen brengt de heer Niemann het volgend rapport uit:

"Het door de Royal Geographical Society aan het Institunt gezonden stuk bevat eene mededeeling omtrent het door deze Society aangenomen beginsel ten opzichte van de schrijfwijze van geographische namen door Engelschen. Ik stel voor deze mededeeling met dankbetuiging aan te nemen voor kennisgeving en merk voorts nog op dat de spelling van inlandsche namen in het algemeen, die in de door het Instituut uitgegeven geschriften meestal gevolgd wordt, in vele opzichten overeenkomt met die der Geographical Society; het is echter als een wezenlijk gebrek der spelling van dat genootschap te beschouwen, dat geen onderscheid daarin wordt gemaakt tusschen de schrijfwịjze van namen als Selangur, Ferangganu, Bangil, Lingga, enz., omdat men bij die allen slechts eene $n g$ wil bezigen en dus bv. Linga, in pl. v. Lingga, wil schrijven, hetgeen zoowel met de spelling in het Arabisch-Maleisch karakter als met de uitspraak in strijd is. ${ }^{1}$ Daar het hier niet de plaats is voor eene bepaalde kritiek van dit stelsel van spelling, gaan wij andere gebreken met stilzwijgen voorbij."

Onder dankbetuiging aan den Rapporteur vereenigt de vergadering zich met zijn advies.

Ter tafel wordt gebracht een schrijven van den heer Dr. H. ten Kate, uit Brisbane, Queensland, van 7 December $189 \phi$, houdende antwoord op eene dezerzijds gedane noodiging om, in de plaats van wijlen Dr. Wilken, op de eilanden der Banda-zee een ethnografisch onderzoek in te stellen: eene nondiging, waaraan hịj gaarne gehoor zou willen geven, mits het Instituut eenige door hem gestelde voorwaarden kan aanvaarden, waaromtrent hij gaarne

\footnotetext{
1 Omtrent dit punt vinden wij hier slechts opgemerkt: yng has two separate sounds, the one hard as in te English word finger, te ather as in singer. As to distinghuish between them employed in the same locality, no attempt is made
} 
per telegram aan het adres van den Consul-Generaal der Nederlanden te Melbourne zou ingelicht worden.

Met belangstelling worden de door den heer ten Kate gestelde voorwaarden overwogen, in verband ook met de eischen die het Institunt bij het voorgenomen onderzoek zich gesteld had.

$\mathrm{Na}$ ampele bespreking van de mededeelingen en wenschen des heeren ten Kate wordt met meerderheid van stemmen besloten genoemden geleerde bij telegram te berichten, dat het Instituutsbestuur de door hem gestelde voorwaarden niet kan aannemen, zullende hem daarna een nader met redenen omkleed schrijven worden toegezonden.

In verband met dit besluit wordt door den Secretaris in overweging gegeven alsnu omtrent eene opdracht voor het ethnografisch onderzoek in overleg te treden met de hh. Martin en Baron van Hoëvell, Resident van Amboina, met machtiging aan den Voor-. zitter en Secretaris daartoe het noodige te verrichten.

Dienovereenkomstig wordt eenparig besloten.

Het bestuurslid Kielstra brengt, ook namens zijn medelid Wijnmalen, verslag uit over het door hen gehouden onderzoek van de rekening des Penningmeesters over 1890 , welke door hen in orde bevonden is en mitsdien ter goedkeuring vanwege het Bestuur wordt voorgesteld.

Diencvereenkomstig wordt besloten.

De Secretaris brengt ter tafel een concept van het door hem op de Algemeene Vergadering mede te deelen overzicht van den staat en de werkzaamheden van het Instituut over 1891. Met eenige wijzigingen wordt het goedgekeurd, onder dankbetuiging voor de zorg daaraan besteed.

De vergadering gaat alsnu over tot het opmaken van drietallen ter aanbieding aan de Algemeene Vergadering bij de verkiezing van bestuursleden in de plaats van wijlen Dr. Wilken en de aftredende leden de Groot en Wijnmalen.

Uit de gehouden stemming blijkt dat zullen worden voorgedragen:

$1^{\circ}$. voor de vacature-Wilken de heeren Prof. dr. H. Kern, Prof. dr. J. J. M. de Groot en Prof. O. Poensen;

- 2o. voor de vacature-de Groot, de heeren J. H. de Groot, van Meeteren Brouwer en mr. C. Voute; en 
3․ voor de vacature-Wijnmalen, de heeren dr. T. C. T. Wijnmalen, mr. O. J. H. Graaf van Limburg Stirum en mr. A. J. A. E. Bik.

Vervolgens wordt overgegaan tot de benoeming van nieuwe leden zoowel in Nederland als in Ned.-Indië, en blijkt dat verkozen zijn tot nieuwe leden in Nederland de hh.

Jhr. mr. W. C. A. Alberda van Ekenstein, Lid Eerste Kamer der Staten-Generaal, te Groningen.

J. M. Pijnacker Hordijk, te 's Gravenhage,

H. H. van Beuningen, te Utrecht,

Mr. J. J. S. Harte, te 's Gravenhage,

G. Diepen, te Roermond,

Dr. P. J. F. Vermeulen, te Amsterdam,

H. Seret, te Hof van Delft .

Mr. H. Ph. de Kanter, te Haarlem,

allen leden van de Tweede Kamer der Staten-Generaal.

Jhr. C. H. A. van der Wijck, oud-Vicepresident van den Raad van Ned-Indië, te 's Gravenhage,

P. ten Bosch, Vice-admiraal, laatst Commandant van Z. M. Zeemacht O. I., thans te 's Gravenhage,

Mr. G. A. van Hamel, Hoogleeraar in de rechten aan de Gemeentelijke Universiteit te Amsterdam,

Mr. W. van der Vlugt, Hoogleeraar aan de Rijksuniversiteit, te Leiden,

F. B. Löhnis, Inspecteur van het middelbaar onderwijs, belast met het toezicht over het landbouwonderwijs, te 's Gravenhage ,

A. J. Nijland, Districtschoolopziener te Utrecht,

Jhr. mr. dr. A. D. van Riemsdijk, Voorzitter van het Muntcollegie, te Utracht,

Mr. W. H. Baron van Verschuer, Raad-adviseur bij het Minissterie van Waterstaat, Handel en Nijverheid, te 's Gravenhage,

D. Cordes, President van de Kamer van Koophandel en fabrieken, te Amsterdam,

B. L. Gompertz, Bankier te Amsterdam.

J. J. van Santen, ) Directeuren van de Ned. Ind.

M. Bock, \} Handelsbank te Amsterdam,

J. W. Wilson, Directeur van meerdere Ind. Cultuur-maatschappijen, te Amsterdam,

M. C. Calkoen, Directeur van de Koloniale Bank te Amsterdam, 
Mr. M. C. van Hall, Commissaris der Jav. Cultuur-maatschappij., te Amsterdam,

H. H. Beels, te Haarlem,

Mr. B. R. W. A. baron Sloet van Hagensdorp, Directeur Cultuur-maatschappij Kalibagor, Amsterdam,

Alb. Fr. Insinger, Gedelegeerde van de Javasche Bank, Amsterdam,

J. H. A. A. Kalff, Chef van de firma H. v. Leeuwen en $\mathrm{C}^{\circ}$. Amsterdam ,

M. Teixeira de Mattos, Direct. v. d. Oostersche Handelsvereeniging, Amsterdam,

H. J. Hijmans, Directeur van de Maatschappij voor uitvoer- en commissiehandel te Amsterdam,

P. N. Muller,

H. G. $\delta_{5}$ Crone,

Julius G. Bunge,

Handelaren te Amsterdam,

F. L. S. van Heekeren,

Aug. M. J. Hendrichs,

H. C. Hintzen, Commissaris der Koloniale Bank, te Amsterdam,

F. A. Vriese, Commissaris van de Ned. Ind. Handelsbank, Amsterdam ,

Mr. F. S. van Nierop, Directeur van de Amsterdamsche Bank, Amsterdam,

G. M. Boissevain, particulier, te Amsterdain,

G. Emants, te 's Gravenhage,

Jhr. mr. A. L. J. Melvill van Carnbee, Advocaat te 's Gravenhage, Mr. C. Th. F. Thurkow, Oud-Lid van den Raad van Justitie te Semarang, te 's Gravenhage,

J. W. Mooyen, Oud-resident van Japara, te 's Gravenhage,

Mr. A. M. Oudemans, Oud-resident van Madioen, te Nijmegen,

J. Mullemeister, Oud-retident van Djokjokarta, te Haarlem,

P. J. A. Spaan, Oud-resident van Cheribon, te 's Gravenhage,

S. Stibbe, Oud-resident van Tapanoeli, te Amsterdam,

Jhr. G. G. de Villeneuve, Oud-resident van Timor, te 's Gravenhage,

W. D. J. Bezemer, Kapt.-Intend. van het O. I. leger, m. v.,

te Soest,

Dr. W. A. Terwogt, Predikant te Hoorn,

J. L. Zegers, Oud-zendeling der Ned. Zendingsvereeniging te Indramajoe, thans te Heemstede bij Haarlem,

E. A. Stael van Holstein van Vloten, Oud-assistent-resident van Salatiga; te Arnhem, 
H. H. Juynboll, Letterkundige, Leiden,

J. P. Cambier, Controleur, m. v., te Vianen,

Jhr. mr. H. de Stuers, te 's Gravenhage,

Tot correspondeerend lid:

H. Sundermann, Missionaris op Nias, thans te Moers, Rhijnpruissen.

Tot leden in Nederlandsch-Indië de hh. :

L. P. D. Op ten Noort, Hoofdagent van de Paketvaartmaatschappij, te Batavia.

M. Dames, Lid van de Factory der Ned. Hand.-Maatschappij te Batavia.

H. C. Soeters, id. id. te Batavia.

Mr. C. A. Henny, Hoofdagent N. I. Handelsbank, te Batavia.

Th. J. van Haren Norman, Agent N. I. Handelsbank, te Batavia.

M. F. Henny, Landsadvocaat te Batavia.

V. C. Coster van Voorhout, Hoofdagent Koloniale Bank te Socrabaja.

Mr. C. B. Nederburgh, Referendaris Alg. Secretarie, Buitenzorg.

J. A. van Dorsser, President Alg. Rekenkamer, Batavïa.

Mr. S. J. Lagerwey, Secretaris v. h. Dep. v. Justitie, te Batavia.

Mr. A. Stibbe Lzn., President v. d. Raad v. Justitie, Batavia.

Mr. W. Tadema, President Raad van Justitie, Semarang.

Mr. C. Bosch, President Raad van Justitie, Soerabaia.

Mr. A. M. Pino, id. id. Padang.

Mr. C. W. Baron van Heekeren, Landsadvocaat, Semarang.

H. W. van Ravenswaay, Secretaris Dep. B. B., Batavia.

Mr. J. P. Metman, Resident van Batavia.

J. H. W. Graaf van den Bosch " " Cheribon.

Jhr. L. Th. Hora Siccama " " Pekalongan.

W. C. J. Castens,

A. C. Uljee,

Mr. J. Lublink Weddik

C. M. Ketting Olivier

D. de Wit " " " Bezoeki.
C. H. D. Monod de Froideville, assistent resident, Batavia
C. G. Ottente

C. G. Ottenhoff,

A. van der Gon Netscher,

Resident van Banjoemas.

J. A. Ament,

O. A. Burnaby Lautier

J. D. Harders,

F. D. Wittenrood,

" Japara.

" Rembang.

" Madoera.

" Djocjokarta.

" Bezoeki. 
U. L. van Tubergen, Secretaris van Sumatra's Westkust.

P. M. van Hengst, Resident van de Lampongs.

J. P. de Vries, Resident vail Palembang.

E. W. E. Burger, Resident van Riouw en Onderh.

H. J. Hooghwinkel, Resident van Banka.

M. C. E. Stakman, Resident van Menado.

M. C. Dannenborgh, Resident van Bali en Lombok.

Jhr. J. G. O. S. von Sinidt auf Altenstadt, Resident van Madioen.

W. Buurman, Inspecteur v. h. boschwezen, te Batavia.

H. J. Hardeman, Directeur Gymnasium Willem III, Batavia.

Dr. F. J. van Buuren, Directeur H. B. School, Soerabaja.

Mr. J. Tersteeg, Redacteur Javabode, Batavia.

P. A. Daum, Redacteur Bat. Nieuwsblad, Batavia.

J. A. Anschutz, Officier van gezondheid te Paja Combo, Sum. W. K.

W. F. van Zutphen, Aspirant-controleur te Indramajoe.

G. J. Oudemans, Controleur der 2de klasse te Djokjokarta.

C. Oudemans, te Djokjokarta.

H. D. Helderman, Controleur te Batang Toroe, res. Taponoeli.

J. P. van Diest, Controleur 1ste klasse te Moeara Enim. res. Palembang.

J. L. van Gennep, Controleur lste klasse te Probolinggo.

J. Scheel, Controleur 2de klasse in de residentie Cheribon.

Mr. D. W. K. de Roo de la Faille, Ambtenaar bij het Departement van Justitie te Batavia.

F. de Roo de Faille, Aspirant-controleur te Tjitjalengka in de Preanger-Regentschappen.

Van deze keuze zal aan de Algemeene Vergadering mededeeling worden gedaan.

Niets meer aan de orde zijnde wordt de vergadering door den Voorzitter gesloten. 


\section{ALGEMEENE VERGADERING,}

GEHOUDEN 27 FEBRUARI 1892.

Tegenwoordig de hh. der Kinderen (Voorzitter), N. P. van den Berg (Onder-Voorzitter), I. W. C. van den Berg, J. H. de Groot, Kielstra, Niemann, Quarles van Ufford, Schlegel, Vreede en Wijnmalen, leden van het Bestuur; voorts de hh. leden: de Roo, van Goltstein, Buys, C. Voûte, van Lith de Jeude, Horst, Trap, C. W. Pleyte, Kern en van Limburg Stirum.

De Voorzitter, mr. T. H. der Kinderen, opent de vergadering en heet de opgekomen leden welkom, onder het uitspreken van den wensch, dat de jaarlijksche bijeenkomst, waarin rekenschap wordt gevraagd en gegeven van hetgeen er in het afgeloopen jaar verricht werd, moge blijken den bloei van het Instituut te bevorderen.

De notulen van de vorige Algemeene Vergadering, den 28 Februari 1891 gehouden, welke bereids door het Bestuur voorloopig gearresteerd zijn, worden voorgelezen en, daar niemand daartegen eenige bedenking had, definitief goedgekeurd, waarna het woord wordt verleend aan den Secretaris, die, overeenkomstig de bepalingen van het Reglement, namens het Bestuur verslag uitbrengt van den staat en de werkzaamheden van het Instituut over 1891.

Onder toejuiching der vergadering zegt de Voorzitter den Secretaris dank voor het door hem geleverd overzicht en stelt voor het op de gewone wijze in de eerstvolgende aflevering der Bijdragen te doen drukken. (Zie hierachter blz. XLVII.)

Dienovereenkomstig wordt zonder beraadslaging of hoofdelijke steuning besloten.

Naar aanleiding van het Verslag van den Secretaris vraagt de hẻer Quarles van Ufford eenige inlichtingen omtrent de uitgave van den tekst, behoorende bij de bereids verschenen Wajangplaten, 
welke tekst, door den heer Dr. Serrurier bewerkt, blijkens een in de vorige Algemeene Vergadering medegedeeld verslag toen reeds spoedig kon worden tegemoetgezien.

De Secretaris zegt tot zijn leedwezen hierop het antwoord schuldig te moeten blijven, doch is bereid bij den heer Serrurier daarover inlichtingen in te winnen, waarop het lid C. M. Pleyte mededeelt juist korten tijd geleden te hebben vernomen, dat de uitgave van den bedoelden tekst zeer spoedig kan worden verwacht.

In aansluiting aan hetgeen in het Verslag wordt gezegd omtrent de onderzoekings-reis van den hoogleeraar Dr. K. Martin doet de hoogleeraar Kern uit een van den heer Martin te Leiden ontvangen schrijven eenige mededeelingen omtrent de door hem verkregen resultaten en van de autoriteiten ondervonden hartelijke medewerking.

De Secretaris voegt hieraan de mededeeling toe, dat juist ná het vaststellen van zijn jaarverslag van den Minister van Koloniën dd. 20 Februari jl. Letter $A^{1}, n^{0}$. 6, een schrijven is ontvangen, waarbij wordt kennis gegeven, dat blijkens een van den GouverneurGeneraal van Nederlandsch-Indië ontvangen telegram voor het loopende jaar eene Regeeringssubsidie van $f 10.000$ is verleend ten behoeve der voortzetting van het vanwege het Instituut ondernomen wetenschappelijk onderzoek: welke mededeeling met toejuiching wordt ontvangen.

Aan de orde is vervolgens de rekening en verantwoording van den Penniugmeester over 1891, welke, vanwege het Bestuur nagezien door de heeren Kielstra en Wijnmalen, daarna in handen is gesteld van eene Commissie van twee gewone leden, zijnde de heeren H. D. Canne en Mr. C. Voute.

$\mathrm{Bij}$ monde van laatstgenoemde wordt daarorer rapport uitgebracht, waaruit blijkt, dat de rekening van den Penningmeester door de Comınissie is nagezien, met de justificatoire bescheiden vergeleken en in volkomen orde is bevonden, waarom zij niet aarzelt der vergadering voor te stellen de rekening goed te keuren en den Penningmeester te déchargeeren, onder dankbetuiging voor zijn zorgvuldig beheer.

Bij acclamatie vereenigt de vergadering zich met dit voorstel, waarna den Penningmeester het woord wordt verleend, die ten aanzien van de kas en de balans de volgende mededeelingen doet: 
10. ten aanzien der kas:

$a$. De ontvangsten gedurende het jaar 1891 hebben bedragen . f 15798.9$]$

als : voor ontvangen contributie 1891 in Neder-

land. . . . . . . f 4385.-

" " contributie 1891 in Indië " 2021.98

" " lokaalhuur van het Indisch

Genootschap 1891 . . " 400.-

" " van den heer Mart. Nijhoff

voor verkochte werken in

1891 na aftrek v. 35 pCt. " 1358.69

interest-rekening Coup. 5 Cert. N.W.S. " 173.24

" recht van vertaling in het Engelsch

v/h werk van Dr. Snouck-Hurgronje " 360." ontv. van het Ministerie van Koloniën

voor subsidie voor de levering van

exemplaren van het werk van den heer

J. van der Toorn . . . . . . " 2100.

" ontv. van het Ministerie van Koloniën

voor het wetenschappelijk onderzoek

der eilanden van de Banda-zee. . " 5000.-

te zamen $\overline{\text { f } 15798.91}$

Het saldo in kas op $1^{\circ}$ Januari 1891 bedroeg " 269.63

Totaal bedrag der kas $1891 \overline{\text { f } 16068.54}$

b. De uitgaven over $] 891$ beliepen als volgt:

voor assurantie van het gebouw . . . . f 33.45

" grondbelasting . . . . . . . . . " 108.50

" onderhoud van het gebouw en schoon-

houden .

" personeele belasting . . . . . . . 39.43

" verwarming der lokalen . . . . . " 141.55

" gasverlichting f 60.35 . - Duinw. f 30 " 90.35

" salaris van den Concierge . . . . " 450 .

" salaris van den Schrijver. . . . . " 200.-

" onkosten Penningmeester . . . . . " 140.05

" " Secretariaat en Bibliotheek. " 500.

" honorar. aan Schrijvers in de Bijdragen. " 7411.23

" kosten drukken der Bijdragen . . . " 1402.43

" " " afzonderlijke werken . " 588.62

Transporteeren. . . f 47]2.09 
Per transport. . f 4712.09

Voor uitbreiding der Boekerij . . . . . " 722.98

" kosten der verzending v/d Bijdragen. " 372.86

" " drukken Minangk. Woordenb. " 1969.50

" " Min. v. Buit. Zaken voor den

Consul te Colombo(Lapidarium) " 446.34

" wetenschappelijke reis Dr. Martin. . " 5000.-

" gekocht 2 certif. N. W. S. $n^{0} .33621$ en $n^{0} 33197$. . . . . . . . . .

Kas op 31 Dec. '91 f 15265.91

Hierbij geteld het saldo " 802.63 f 16068.54 overeenkomende met de som der ontvangsten hierboven vermeld.

20. De balans.

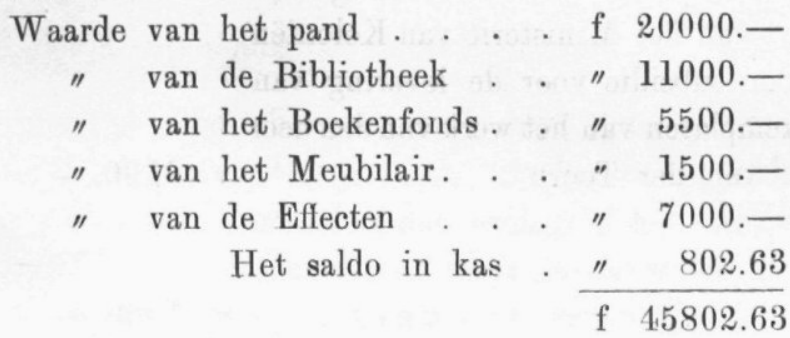

In het afgeloopen jaar sloot de balans met

het cijfer . . . . . . . . . . " 43269.63

Alzoo in 1891 vooruitgegaan met $\mathrm{f}$ 2533.-

De waarde van het gebouw is op f $20 / \mathrm{m}$ gebleven, omdat gedurende vorige jaren reeds voor een bedrag van $\mathrm{f} 6500$ was afgeschreven. Bij aankoop en aangebrachte verbeteringen kostte het pand f $26 \frac{1}{2} / \mathrm{m}$. Het Bestuur heeft gemeend de waarde daarvan thans op $20 / \mathrm{m}$ te moeten houden, een som die z. i. bij verkoop altijd te maken zal zijn.

De waarde van de Bibliotheek, het Boekenfonds en het Meubilair zijn eveneens op de taxatiën als in het afgeloopen jaar gebleven. Het angekochte tot uitbreiding en vernieuwing van een en ander, tot een bedrag van f 722.98, is als afschrijvingspost beschouwd.

Op het Instituut rust geen schuldenlast meer. Alle rekeningen zijn betaald.

Het debiet van het werk van Dr. Snouck-Hurgronje "Mekka" is bevredigend. De verantwoording van den verkoop hiervan bedroeg volgens den heer Martinus Nijhoff pm. f 1000. -, zoodat verwacht 
mag worden dat de kosten van deze uitgave binnen een paar jaren gedekt zal zijn.

Het Ledental is in het afgeloopen jaar nagenoeg hetzelfde gebleven. Het Bestuur beveelt de leden aan om het getal meer en meer te doen toenemen."

Namens de vergadering zegt de Voorzitter den Penningmeester dank voor zijne mededeelingen, naar aanleiding waarvan het lid van Limburg Stirum eenige inlichtingen vraagt omtrent de 35 pCt., die den heer Nyhoff als uitgever van het Instituut worden toegekend en hem nog al hoog voorkomen. De Penningmeester antwoordt, dat vroeger zelfs 40 pCt. werd in rekening gebracht, doch eerst sedert eenige jaren, hoewel niet zonder strijd, het tegenwoordig cijfer kon verkregen worden.

De Voorzitter stelt vervolgens aan de orde de verkiezing van Bestuursleden in de plaats van wijlen Prof. G. A. Wilken en de aftredende leden .T. II. de Groot en dr. T. C. I. Wijnmalen en benoemt tot stemopnemers de hh. van der Horst en Trap, die na de gehouden stemming rapporteeren, dat met groote meerderheid uit de voorgedragen drietallen gekozen is :

voor de vacture-Wilken de hoogleeraar dr. H. Kern, en voor de periodieke aftreding der hh. de Groot en Wijnmalen dezelfde titularissen.

De Voorzitter dankt de stemopnemers voor de vervulling hunner taak, terwijl zijne vraag, vervolgens tot de nieuw-verkozen Bestuursleden gericht of zij zich de keuze laten welgevallen, door hen bevestigend wordt beantwoord.

Onder herinnering aan hetgeen bereids door den Secretaris in zijn jaarverslag werd medegedeeld, brengt de Voorzitter namens het Bestuur het voorstel aan de orde, om, ingevolge al. 2 van art. 13 van het Reglement, het vanwege het Insíituut uit te geven plaatwerk van den heer dr. J. Groneman "Tjandi Prambanan op MiddenJava na de ontgraving", alleen voor de leden verkrijgbaar te stellen tegen de helft van den handelsprijs.

Niemand verlangt over dit voorstel het woord, evenmin hoofdelijke stemming; bij acclamatie vereenigt de vergadering zich daarmede.

De Voorzitter herinnert aan de bezwaren, die telkens zich voor- 
doen met betrekking tot het tijdstip waarop men van het lidmaatschap kan afzien, zonder tevens gerekend te worden alsnog verplicht te zijn de contributie te voldoen; ter opheffing dier bezwaren stelt het Bestuur daarom voor in art. 6 van het Reglement, handelende over de contributie, eene $4^{e}$ alinea toe te voegen luidende: "Wanneer men wil ophouden lid te zijn, is men verplicht daarvan keunis te geven vóor den aanvang van het jaar."

Met 't oog op de omstandigheid dat niet vermeld wordt aan wien de kennisgeving van het ontslag moet geschieden, stelt het lid de Roo voor an het artikel alsnog toe te voegen de woorden: "in Europa aan het Bestuur in Nederland, in Oost- en West-Indië aan de Commissarissen of Gedelegeerden."

Namens het Bestuur verklaart de Voorzitter dit amendement over te nemen, waarna het voorstel, aldus gewịzzigd in omvraag gevraagd, zonder hoofdelijke stemming wordt goedgekeurd.

De Voorzitter geeft hierna het woord aan den Secretaris, die mededeeling doet van den uitslag der keuze van nieuwe leden. (Zie de namen in de Notulen der Bestuursvergadering van 20 Februari 1892).

Bij de rondvraag wordt door den heer C. Voute, uit naam van vele leden, de wensch uitgesproken dat in het vervolg de Algemeene Vergadering later, bijv. eerst ten 2 ure, te doen aanvangen, ook ten gerieve van de leden die van elders komen. De heeren Kern, Schlegel en L. W. C. van den Berg ondersteunen dezen wensch. De Voorzitter belooft dat het Bestuur zal trachten dienovereenkomstig te handelen.

De heer Kern brengt ten slotte uit naam van alle aanwezigen hulde aan den Voorzitter voor de uitnemende leiding der vergadering, waarna de bijeenkomst door den Voorzitter gesloten wordt onder dankbetuiging voor aller anwezigheid. 


\title{
BUITENGEWONE BESTUURSVERGADERING
}

\author{
GEHOUDEN 27 FEBRUARI 1892.
}

Tegenwoordig de hh. der Kinderen, N. Y. van den Berg, . L. W. C. van den Berg, J. H. de Groot, Kern, Kielstra, Niemann, Quarles van Ufford, Schlegel, Vreede en Wijnmalen. Afwezig de heer van der Pant.

De heer der Kinderen, de voorzittersplaats innemende, verzoekt het Bestuur, overeenkomstig art. 9 van het Reglement uit zijn midden een Voorzitter, Ondervoorzitter, Penningmeester en Secretaris te kiezen; hij veroorlooft zich echter te doen opmerken, dat hij, het vorige jaar in de plaats des heeren Kern tot Voorzitter gekozen, zich die keuze heeft laten welgevallen, doch dat, waar de hoogleeraar nu weder als Bestuurslid is opgetreden, aan hem meer eigenaardig de leiding van het Instituut behoort.

Bij de hierop gevolgde stemming vereenigen zich 8 stemmen op den heer der Kinderen en 3 op den heer Kern, zoodat eerstgenoemde als Voorzitter herkozen is, die, onder dankbetuiging voor het hem geschonken bewijs van vertrouwen, verklaart zich aan den wil der meerderheid te willen onderwerpen.

Bij de keuze van een Ondervoorzitter verklaart de heer N. P. van den Berg, dat hij in het afgeloopen jaar telkens om ambtsbezigheden afwezig moest zijn, hetgeen hij vreest dat in het vervolg eveneens het geval zal zijn, waarom hij verzoekt hem niet meer voor de betrekking van Ondervoorzitter aan te wijzen.

$\mathrm{Bij}$ meerderheid van stemmen wordt daartoe vervolgens de hoogleeraar Kern aangewezen, die verklaart de op hem uitgebrachte
keuze te aanvaarden.

Voor de vervulling van het Penningmeesterschap en het Secretariaat worden bij acclamatie aangewezen de hh. de Groot en Wijnmalen, die zich bereid verklaren de hun opnieuw opgedragen taak
te blijven vervullen.

Niets meer verder aan de orde zijnde, wordt de buitengewone bestuursvergadering door den Voorzitter gesloten. 


\title{
VERSLAG
}

\author{
VAN DEN \\ STAAT EN DE WERKZAAMHEDEN \\ VAN HET
}
KONINKLIJK INSTITUUT V0OR DE TAAL-, LAND- EN VOLKENKUNDE VAN NED.-INDIË OVER 1891

UITGEBRACHT IN DE ALGEMEENE VERGADERING, GEHOUDEN

DEN $27^{\text {en }}$ FEBRUARI 1892.

\section{Mijne Heeren!}

Weemoedige herinneringen, tegenover velerlei teleurstellingen niet weinige verblijdende feiten, benevens hoopvolle verwachtingen: ziedaar in weinige woorden te samengevat wat het afgeloopen jaar 1891 voor het Instituut is geweest en heeft opgeleverd.

Weemoedige herinneringen, zeiden wij. Immers, hoevelen zijn ons weder in den afgeloopen tijdkring door den dood niet ontvallen! Wij noemen $U$ slechts de namen van den Gepensioneerden ViceAdmiraal Binkes, van ons Amsterdamsch medelid A. A. Bienfait, van den oud-raad van Indië S. van Deventer, van den voormaligen Inspecteur van het Inlandsch onderwijs S. van Dissel, van den geleerden natuurvorscher Dr. Hartogh Heys van Zouteveen, van den Directeur der Billiton-Maatschappij M. A. van Walcheren; waarbij Gij nog kunt voegen de namen van twee onzer Indische medeleden: den Indischen Industrieel C. van Baumgarten en den Resident der Preanger-Regentschappen J. Heyting; eindelijk, van ons correspondeerend lid, den oud-Consul-Generaal van Brazilië, M. L. van Deventer. Zonder nadere aanwijzing zult Gij zelf de mate van de verliezen erkennen, die het Instituut door hun overlijden gelerlen heeft. En werden deze verliezen in verschillende onzer kringen diep gevoeld, zeker niet 't minst werd onze kleine Bestuurskring getroffen, waar wij den zetel, op de vorige jaarvergadering nog zoo waardig ingenomen door onzen Wilken, al spoedig 
daarna onbezet moesten zien. Waar reeds op velerlei wijze en door zoovele bevoegden hulde is gebracht aan de nagedachtenis van onzen geleerden Ethnograaf, vergt Gij het zeker niet van ons, dat wij thans ter dezer plaatse opnieuw zijne veelzijdige verdiensten in het licht stellen en den omvang doen kennen van het verlies, dat in het bizonder ook het Instituut door het overlijden van zijn Bestuurder heeft geleden. Te minder noodig mag dit geacht worden, waar de zoo bekwame hand van onzen Voorzitter bereids in ons midden en wel in de jongste aflevering onzer Bijdragen een waardig "In Memoriam" aan Dr. G. L. Wilken heeft gewijd. Huldigen wij zijne nagedachtenis ook daarin, dat wij straks de door hem ledig gelaten plaats doen innemen door een hem waardigen opvolger!

Ontrukte de dood meer dan een onzer leden uit onzen kring, niet minder leed doet het ons, waar ons ook in het vorige jaar de droeve taak werd opgelegd om van de lijst onzer leden meer dan éen af te voeren, van wien het bericht ous gewerd, dat men zich "om redenen van persoonlịken aard" verplicht gevoelde ons zijne verdere medewerking te onthouden. Gelukkig dat hun getal betrekkelijk klein is, en geen invloed uitoefent op het cijfer onzer leden, dat, na aftrek ook der verliezen tengevolge van overlijden, thans bedraagt 537, waarvan in ons vaderland 5 Donateurs, 5 contribueerende instellingen, en 328 gewone leden, en in de overzeesche bezittingen en koloniën 199 gewone leden. Van de namen onzer 3] buitenlandsche leden, alsmede van die onzer 2 Eereleden behoefden wij gelukkig geen enkelen af te voeren; alléen het drietal correspondeerende leden werd tot 2 teruggebracht.

Nevens de verliezen, die wij in 1891 hadden te boeken, was ons ook eene andere en diepgevoelde teleurstelling bereid. Gij herinnert $U$, dat wij, als gevolg van het eenparig genomen besluit der vorige Algemeene Vergadering, aan Hare Majesteit de Koningin-Regentes het eerbiedig verzoek hebben gericht om, in de plaats van wijlen onzen geëerbiedigden Koning, als Beschermvrouw op te treden. Ingevolge de bevelen van Hare Majesteit werd ons, onder dagteekening van den 3 Maart van het vorige jaar, medegedeeld, dat, hoewel Hare Majesteit het tot Hoogstdezelve gericht verzoek op hoogen prijs stelt, Hare Majesteit echter vermeent, dat eene Instelling als de onze meer eigenaardig onder de bescherming zoude moeten staan van het Hoofd van den Stat, waarom in over- 
weging werd gegeven dit verzoek later te richten tot Hare Majesteit de Koningin Wilhelmina, zoodra Hoogstdezelve persoonlijk de regeering zal hebben aanvaard.

Deze mededeeling zal U, M.H., evenals ons, zeker met diep leedwezen vervullen. Terwijl wij de redenen eerbiedigen, die Hare Majesteit de Koningin-Regentes hebben geleid om geen gunstig gevolg te geven aan het tot H. D. gericht verzoek, houden wij ons overtuigd, dat ook Gij met ons op hoogen sprijs stelt de verklaring te mogen vernemen, dat, afgescheiden van het medegedeeld inzicht, "het Harer Majesteit ten allen tijde aangenaam zal zijn "Hare groote belangstelling te kunnew toonen in deze wetenschappe"lijke Instelling, van welke wijlen Z. M. de Koning Beschermheer was."

Met voldoening mag inmiddels er op gewezen, dat Harer Majesteits Regeering, ook in het afgeloopen jaar, is voortgegaan met aan onze Instelling haren veelvermogenden steun te verleenen. Zoowel bij het Departement van Koloniën als bij de Indische Regeering werd nimmer te vergeefs aangeklopt.

Naar aanleiding van een door ons Bestuur gedaan verzoek werd door Z.Exc. den Minister van Koloniën van de verhandeling van wijlen den hoogleeraar Dr. G. A. Wilken over "De verbreiding van het matriarchaat op Sumatra," voorkomende in deel III van de Bijdragen, blz. 163 vv., een aantal exemplaren naar Indië gezonden, ter uitreiking aan de Ambtenaren op Sumatra, met uitnoodiging onderzoekingen in te stellen, ten einde de bestaande leemten aan te vullen. Door onderscheidene zeudelingen en ambtenaren bij het Binnenlandsch Bestuur werd daaraan met de meeste bereidvaardigheid voldaan en nota's ingezonden, die wij door de welwillende tusschenkomst van het Ministerie van Koloniën mochten ontvangen nog tijdens het leven van den hoogleeraar Wilken, in wiens handen zij dan ook ten gebruike werden gesteld. Voor eene afzonderlijke uitgave waren de meeste van die nota's naar het oordeel van genoemden hoogleeraar, door haren fragmentarischen aard en niet zelden door den missive-vorm waarin zij gestoken zijn, minder geschikt. Zij bevatten echter - en hiervoor komt aan de samenstellers de dank der wetenschap toe - vele belangrijke gegevens, die, aangevuld met hetgeen van elders over het onderwerp bekend is, wijlen den hoogleeraar Wilken hebben in staat gesteld eene eenigszins volledige schets te ontwerpen van de verschillende ontwikkelingsvormen van het huwelijks- en erfrecht op Zuid-
5 e Volgr. vII. 
Sumatra, welke wij mochten opnemen in de $2^{\mathrm{e}}$ afl. van het zesde deel, $5^{\mathrm{e}}$ volgreeks onzer Bijdragen.

Over de nota's zelve veroorlooven wij ons belangstellenden verder te verwijzen naar het zaakrijk verslag, daaromtrent door onzen medebestuurder Prof. Mr. L. W. C. van den Berg uitgebracht en opgenomen in de Notulen onzer Bestuursvergadering van Januari jl.

Een tweede arbeid, waarbij wij den steun mochten ondervinden zoowel van het Departement van Kolonien als van dat van Buitenlandsche Zaken, betreft een herhaaldelijk behandeld onderwerp: het verzamelen namelijk van de noodige bouwstoffen voor eene eventueele samenstelling van een Indisch Lapidarium. Opnieuw mochten wịj van beide Departementen verschillende gegevens daarvoor erlangen, waaromtrent wij hopen weldra een uitgewerkt verslag te kunnen aanbieden, dat, gelijk vroeger was aangekondigd, reeds in de Bijdragen zou zijn opgenomen, ware het niet dat de ontvangst van nieuwe bouwstoffen telkens eene revisie en uitbreiding van ons overzicht noodig maakte.

In den aanvang van het vorige jaar mocht ons Bestuur de aandacht van den Minister van Koloniën vestigen op den belangrijken ontgravingsarbeid van den voet der drie hoofdtempels van de Tjandigroep te Prambanan, op Midden-Java, ondernomen door de Vereeniging voor oudheid-, taal-, land- en volkenkunde te Jogjokarta

Dezer dagen mochten wij van Dr. J. Groneman een verslag van dien arbeid ontvangen, waarbij een 6 ttal prachtig uitgevoerde fotografieën en $\underset{\sim}{ }$ kaarten gevoegd zijn. Een daaromtrent ingesteld onderzoek heeft ons tot de overtuiging geleid dat eene uitgave daarvan èn uit een wetenschappelijk oogpunt èn in het belang der archaeologische studiën in 't bizonder mag worden aanbevolen, waarom dan ook daartoe het besluit werd genomen; doch, waar het bij ons onderzoek bleek, dat de uitgave van het werk, vooral echter de reproductie van de fotografieën, de draagkracht van het Instituut zou overschrijden, hebben wij vrijheid gevonden voor het tot stand komen dezer kostbare onderneming eene subsidie van de Regeeriug aan te vragen, welke wij niet twijfelen of zij zal aan het Instituut worden verleend. Inmiddels echter meenen wij onzerzijds reeds nu eene poging te mogen doen om de kosten der voorgenomen uitgave niet noodeloos te verhoogen door haar aan al onze leden op de gewone wijze uit te reiken. Onder $n^{0}$. IV van het convocatiebiljet voor deze vergadering hebt Gij daarom een voorstel vermeld 
gevonden, waarbij $\mathrm{U}$ in overweging wordt gegeven, ingevolge al. 2 van Art. 18 van ons Reglement, het uit te geven plaatwerk alléen tegen de helft van den boekhandelsprijs voor de leden verkrijgbaar te stellen. Hoorst waarschịjnlijk zal de uitgave reeds in den loop van het nu reeds ingetreden jaar kunnen worden tegemoetgezien.

Eene andere uitgave, waarover wij reeds in ons vorig verslag melding hebben gemaakt en waarbij wij eveneens den gewaardeerden steun der. Regeering hebben mogen ondervinden, heeft bereids aan het einde van den zomer des vorigen jaars het licht gezien. Wij bedoelen het Minangkabausch-Maleisch-Nederlandsch Woordenboek, bewerkt door ons medelid J. L. van der Toorn. Ook van deze uitgave werden overeenkomstig het in de vorige Algemeene Vergadering genomen besluit, aan de leden exemplaren uitgereikt tegen de helft van den boekhandelsprijs, die door ons in overleg met onzen Uitgever op $\mathrm{f} 8$ is gesteld. Wij houden ons overtuigd, dat deze eerste proeve om ons met het Minangkabausch meer volledig bekend te maken door onze linguisten met belangstelling en dankbare waardeering jegens den geëerden bewerker zal zijn ontvangen, welke voor hem eene aansporing zal zijn om binnen een niet al te lang tijdsverloop onze literatuur alsnog te verrijken met eene Minangkabausch-Maleische grammatica, benevens eene bloemlezing uit Minangkabausche geschriften; met de samenstelling daarvan kon de heer van der Toorn gedurende zijn verloftijd hier te lande niet gereed komen, doch $b_{j}$ zijne terugkomst in Indië hoopte hij die te kunnen voortzetten en beeindigen; en waar eene eventueele herplaatsing in de Padangsche Bovenlanden aan ons medelid de door hem gewenschte gelegenheid zou kunnen aanbieden tot voortzetting en voleindiging zijner studiën van de Minangkabausche taal, heeft het Bestuur niet geaarzeld daartoe de medewerking van den Minister van Koloniën, en, door diens tusschenkomst, die der Indische Regeering in e roepen. $\mathrm{W}_{\mathrm{ij}}$ hopen, dat aan den wensch des heeren van der Toorn zal worden voldaan.

Kan uit een en ander blijken, dat het Instituut bij voortduring zich mag verheugen over den steun, dien het bij zijn arbeid van de zijde der Regeering ondervindt, dankbaar mogen wij vooral gewag maken van de medewerking, door ons genoten ter zake van het door het Instituut in te stellen wetenschappelijk onderzoek van de 
eilanden der Banda-zee, waarvan het geognostisch gedeelte door ons was opgedragen aan den hoogleeraar Dr. K. Martin, terwijl het een der vurigste wenschen van wijlen ons medelid Wilken was zich met ethnografische en linguistische onderzoekingen in die streken te zien belast.

Over dezen belangrijken onderzoekingstocht behoeven wij hier ter plaatse niet verder in bizonderheden te treden. Het wetens:vaardige, wat daaromtrent vooralsnog valt mede te deelen, is met groote uitvoerigheid opgeteekend in de Notuleu van onze Bestuursvergadering van 14 September 1891, die wị, gelijktijdig met dit Verslag, U in druk hopen aan te bieden. Hier alleen dient vermeld, dat aanstonds na het overlijden van den hoogleeraar Wilken door ons Bestuur pogingen zijn aangewend om diens voornaam aandeel bij het voorgenomen onderzoek aan een anderen deskundige op te dragen. De onderhandelingen, door ons daaromtrent gevoerd, zijn nog niet geëindigd en kunnen eerst dan met vrucht afloopen, wanneer ons het besluit der Indische Regeering zal zijn uitgereikt omtrent de beschikbaarstelling der som, welke ten behoeve van wetenschappelijke onderzoekingen in het tweede hoofdstuk der Begrooting van NederlandschIndië voor 1892 is uitgetrokken.

Terwịl wij hopen, dat te zijner tịjd een volledig verslag van den loop en de vruchten dezer onderzoekingsreis zal kunnen worden aangeboden, mogen wij thans echter van het onderwerp niet afstappen, zonder onzen diepgevoelden dank te betuigen voor de krachtige medewerking, die het Instituut van zoovele zijden tot het welslagen van het beoogde doel mocht ondervinden. Zijn wij in de eerste plaats erkentelijk aan de Regeering, zoowel hier te lande als in Indië, voor den door haar verleenden materieëlen en zedelijken steun, ten zeerste gevoelen wij ons ook verplicht aan de Directiën van de Stoomvaart-Maatschappij Nederland en van de Koninklijke Paketvaart-Maatschappij voor de belangrijke reductie die zij wel voor onze onderzoekers hebbeu willen toestaan op het passage en goederentarief: door welke vrijgevige daad zij blijk hebben gegeven van het hooge belang, dat zij in wetenschappelijke onderzoekingen in onze overzeesche bezittingen en koloniën toonen te stellen.

Te midden der velerlei beslommeringen, die de voorbereiding dezer onderzoekingsreis en de verzekering van haar goeden loop uit den aard der zaak in het afgeloopen jaar moesten eischen, 
werden, voor zooveel dit doenlijk was, andere belangen niet ter zijde gesteld.

Reeds wezen wij U op de verschijning van Van der Toorn's Minangkabausch Woordenboek; op de voorgenomen uitgave van het plaatwerk van Dr. J. Groneman over Tjandi Prambanan op MiddenJava na de ontgraving. Hierbij mogen wij nog voegen dat, gelijk wij reeds in ons vorig Verslag mochten aankondigen, met de uitgave van het werk van den heer Léon van de Polder over de geschiedenis van Japan een begin is gemaakt: welke uitgave langzaam vordert met het oog op de moeilijkheden, die zich daarbij telkeus voordoen, met betrekking vooral tot de correctie der in het werk voorkomende Japansche woorden en uitdrukkingen. Wij hopen intusschen dat het eerste deel nog in 'dit jaar zal kunnen 't licht zien.

Met meer spoed wordt echter de vierde door ons te bezorgen uitgave voorbereid: wij bedoelen den nieuwen druk van des hoogleeraaars Niemann's Bloemlezing van Maleische geschriften. Volgens de overeenkomst, die wij omtrent den druk daarvan met de firma Trap te Leiden hebben gesloten, kan de uitgave reeds tegen den a. s. zomer worden tegemoetgezien. Daardoor zal, tengevolge van de gedurige aanvragen naar dit werk, in eene bestaande behoette worden voorzien, terrijl de nieuwe druk, met de bezorging waarvan ons medelid Niemann zich weder heeft willen belasten, door des hoogleeraars eigene nauwgezetheid niet enkel een bloote herdruk, doch inderdaad eene verbeterde en herziene uitgave belooft te zijn.

Nevens de bezorging dezer vier afzonderlijke werken, werd in het afgeloopen jaar geregeld elke drie maanden voortgegaan met de uitgave van het Tijdschrift van het Instituut, de Bịdragen, waarvan het $40^{\circ}$ deel in 4 afleveringen het licht zag, terwijl bereids in Januari jl. de eerste aflevering van een volgend deel verschenen is. Terwijl ter plaatsing in dit ons orgaan velerlei opstellen waren ingezonden, is de voorraad copy voor de volgende afleveringen bestemd, meer dan voldoende aanwezig, zoo zelfs dat wellicht met de verschillende schrijvers in overleg zal moeten worden getreden over den tijd waarop hunne bijdragen zouden kunnen worden opgenomen.

Aan de in de reeds verschenen aflevering opgenomen taalkundige bijdragen over het Galelareesch, zullen door de hoogleeraren Kern en 
Niemann en den zendeling Sundermann studiën worden toegevoegd over het Sawuneesch, Rottineesch en Niasissch. Werd tot dusver ons orgaan geregeld door nu wijlen Dr. Wilken verrijkt met zoo menige ethnografische bijdrage, eene studie van dien aard bezorgde diens opvolger, Dr. J. J. M. de Groot, in de vorige aflevering door zijne bijdrage over de lijkbezorging der Emoy-Chineezen, terwijl wij alsnog opstellen hebben te plaatsen van ons medelid C. M. Pleyte $W_{\text {zn }}$. en den controleur Westenberg. Waar eerstgenoemde ons nader kennis wil doen maken met de plechtigheden en gebruiken uit den cyclus van het familieleven der volken van den Indischen Archipel, wenscht de tweede zich uitsluitend te bepalen tot eenige mededeelingen omtrent de godsdienstige begrippen der Karo-Bataks, terwijl de zendeling J. H. Meerwaldt te Pansoernapitoe, Silindoeng, Sumatra's Westkust, de vraag beantwoordt, of de tegenwoordige zeden en gewoonten der Bataks nog sporen aanwijzen van een oorspronkelijk matriarchaat.

Wat het terrein der historie betreft, onze medebestuurder Kielstra wenscht voort te gaan ons daarbij tot een gids te zijn: van zijne hand gewerd ons reeds sedert geruimen tijd eene vervolg-studie over Sumatra's Westkust, ditmaal sedert het jaar 1850.

Voegen wij hierbij eindelijk nog dat telkens in de Notulen van onze Bestuursvergaderingen de titel van meer dan éene bijdrage is aangekondigd, tot de publicatie waarvan bereids machtiging werd verleend, dan past het der Redactie van ons tijdschrift dankbaar te zijn voor den overvloed van stof waarover zij thans te beschikken heeft nevens eene klachte over gebrek aan plaatsruimte.

Is het ons aangenaam telkens te mogen ervaren, dat de geschriften van het Instituut de aandacht, niet 't minst in het buitenland, trekken, waar mogelijk werd er ook in het vorige jaar naar gestreefd onze werkzaamheden op het terrein der taalland- en volkenkunde van Ned.-Indië bekend te maken hetzij door deelneming aan Congressen, hetzij door een letterkundig verkeer te openen met genootschappen, wier werkkring met den onzen verwant is. Voor zoover het Congressen betreft, ditmaal heeft het Instituut zich enkel kunnen laten vertegenwoordigen op het Internationaal geografisch Congres, dat in de maand Augustus van het vorige jaar te Bern werd gehouden. Ons buitenlansch medelid, Z. H. Prins Roland Bonaparte gunde ons het voorrecht aldaar als onze vertegenwoordiger te willen optreden. 
Met een drietal genootschappen werden betrekkingen aangeknoopt: met name met het Anthropological Institute of Great-Britain and Ireland te Londen, de Anthropological Society of Bombay, te Bombay en de Berliner Gesellschaft für Anthropologie, Ethnologie und Urgeschichte, te Berlijn.

Dank zij vooral het letterkundig verkeer met onderscheidene binnenen buitenlandsche Genootschappen werden ons, in ruil voor de toezending van onze Bijdragen en verder uitkomende geschriften, een aantal genootschapswerken en tijdschriften aangeboden, waardoor telkens aan onze Bibliotheek eeri aanzienlijke schat toevloeit, die door vele belangstellenden dankbaar wordt gewaardeerd.

Nevens de vermeerdering, die onze Bibliotheek daardoor onderging, møchten wij in het afgeloopen jaar telkens een aantal geschenken inschrijven: waaronder het ons een voorrecht is in het bizonder te mogen wijzen op de anbieding, namens de Regeering van Nederlandsch-Indië, van 164 fotografieën van den voet van den Boroboedoer; van een nieuwe serie van fotografiën betreffende Sumatra, ons door ons ijverig medelid Th. Delprat toegezonden; van een antal handschriften, uit de nalatenschap van den oud-Vicepresident van den Raad van Indië $\Lambda$. H. W. Baron de Kock, omtrent den inhoud waarvan wij $\mathrm{U}$ verwijzen naar het verslag daaromtrent uitgebracht in onze Bestuursvergadering van 17 October 1891.

Door de aanzienlijke vermeerdering, die onze boekverzameling jaarlijks door ankkoop en geschenken ondergaat, zal allengs de beschikbare ruimte in ons gebouw geheel zijn ingenomen. Net het oog op deze verblijdende omstandigheid, in verband vooral ook met de meermaleu door onze Zusterinstelling, het Indisch Genootschap, uitgesproken behoefte aan ruimer localen voor hare Algemeene Vergaderingen, werd telkens opnieuw door ons het vraagstuk aanhangig gemaakt eener verbouwing van het tegenwoordig gebouw, of wel van den aankoop van een nieuw en grooter pand. Tot dusver konden wij echter tot geene beslissing hieromtrent geraken, 't geen te moeielijker is, daar elk plan tot verandering of verbetering tot dusver afstuit op de finantieële draagkracht van het Instituut.

Dankbaar mag wèl erkend, dat de toestand onzer financiën alleszins bevredigend is, doch deze is nog niet van zoodanigen aard dat daaruit geene bezwaren zouden kunnen ontleend worden tegen eene eventueele verbouwing of verhuizing. 
Dank zij vooral het zuinig beheer van onzen waardigen Penningmeester, wordt het evenwicht tusschen ontvangsten en uitgaven bewaard. Over 1891 klommen de eerste, met inbegrip van het saldo op 1 Januari 1891, tot een bedrag van $f 16,068.54$; de laatste bedroegen $f 15,265.91$, zoodat op 't einde van het dienstjaar een saldo aanwezig was van $f$ 802.63. De activa over 1890 wijzen een bedrag aan van $f 43,269.63$; over $1891 f 45,802.63$, waaruit op nieuw een belangrijke vooruitgang valt waar te nemen.

In bizonderheden zal dit een en ander blijken uit het rapport der Commissie, die straks aan deze Algemeene Vergadering verslag zal hebben uit te brengen omtrent het finantieel beheer van het Instituut.

Terwijl wij U daarnaar mogen verwijzen, meenen wij Uw aller tolk te zijn, door aan den Penningmeester den dank van het Instituut aan te bieden voor de goede en trouwe zorg, waarmeê hij het beheer der geldmiddelen gevoerd heeft, nu weder over een tijdvak van vier jaren, dat door hem thans kan worden afgesloten, daar voor hem, evenals voor Uwen Verslaggever, het tijdstip is aangebroken om het mandaat van Penningmeester en Secretaris ter Uwer beschikking te stellen. Zij doen dit echter niet, zonder het Bestuur en de overige Leden van het Instituut erkentelijk te zijn voor de vele blijken van sympathieke welwillendheid gedurende hun diensttijd opnieuw ondervonden. Hun, óns aller streven blijve steeds den bloei van ons Instituut naar vermogen te bevorderen!

\section{De Secretaris,}

Dr. T. C. I. Wisnmalen. 


\title{
NAAMLIJST DER LEDEN
}

VAN HET

\section{INSTIITUUT.}

\author{
(10. APRIL 1892.)
}

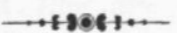

Het getal contribueerende Leden bedraagt 561, waarvan in Nederland 5 Donateurs, 5 contribueerende instellingen, en 350 gewone Leden, en in de overzeesche bezittingen en koloniën 201 gewone Leden. Met 116 wetenschappelijke instellingen en vereenigingen staat het Instituut in betrekking en telt 2 Eereleden, 3 correspondeerende Leden en 31 buitenlandsche Leden.

\section{BESTUUR:}

Mr. т. H. DER KINDEREN, Voorzitter . . . . . . . . . . 1895

Prof. Dr. H. KERN, Onder-Voorzitter . . . . . . . . . . 1896

J. H. DE GROот, Penningmeester . . . . . . . . . . . 1896

Dr. т. c. L. WiJMmalen, Secretaris . . . . . . . . . . 1896

Jhr. Mr. J. K. W. QUARLES VAN UFPORD . . . . . . . . . 1893

Prof. Dr. G. schLEGer . . . . . . . . . . . . . . . 1893

D. P. VAN DER PANT . . . . . . . . . . . . . . . . 1893

Mr. N. P. VAN DEN BERG . . . . . . . . . . . . . . 1894

Prof. A. c. VReede . . . . . . . . . . . . . . . . 1894

Prof. Mr. L. w. c. vaN DEN Berg . . . . . . . . . . . 1894

E. B. KIELStra . . . . . . . . . . . . . . . . . 1895

Prof. G. K. NIEMANN. . . . . . . . . . . . . . 1895 


\section{BUITENLANDSCHE LEDEN.}

Z. H. Prins Roland Bonaparte, Parijs. (22, Cours-la-Reine)

Dr. A. REINHOLD ROST (India Office

Library), Londen.

w. w. HUNTER, Cherwell Edge, Oxford. Prof. ANGelo de GUbernatis, Florence. T. J. HOVELL THURLOW, Londen.

Prof. Dr. albrecht weber, Berlijn.

Prof. emilio teza, Padua. gUIDO CoRA, Turijn.

Dr. FRIEDRICH MüLLER, Weenen.

Prof. georg gerland, Strassburg i/E. Graaf G. H. J. MeIJners D'estrey, Parijs.

6 Place St. Michel.

Mrs. De Croizier, Parijs, 10, Boulevard de la Saussaye, Pare de Neuilly.

Radja sourindro mohun tagore, Mus. Doc., Calcutta.

Dr. A. B. MEIJER, Dresden.

G. DORIA, Genua.

ARISTIDE MARRE, Vaucresson, près St.

Cloud Villa Loiseau, Avenue Vaucresson.

Prof. Dr. G. voN DER GABELENTZ, Berliju.

Prof. Dr. E. H. giglioli, Florence.
Prof. Dr. a. Bastian, Berlijn.

Prof. Dr. R. BRandstetter, Lucern.

Prof. Dr. Jos. конLen, Berlijn, Landgrafenstrasse 4 .

JULes sILVEstre, Rochefort sur mer, 2 Rue des Fonderies (Charente inférieure) Frankrijk.

Prof. PERD. BLUMENTRITT, Leitmeritz (Bohemen.)

x. bRá de saint pol lias, Parijs, 47 rue de Passy.

J. w. Maxwelu, Selangor, Straits Settlements.

Dr. IGNAZ GoldziHER, VII Holló-gasse 4, Budapest.

Dr. THEOD. POSEWITZ, Budapest (Geologisches Institut).

Prof. Dr. p. von RICHTHOFEN, Berlijn (Kurfürstenstr. 117).

Prof. Dr. EDWARD B. TYLOR, Oxford (University-Museum).

Prof. Dr. ERNst KUHN, München.

Sydney J. HIKson, Saville Club 109 Piccadilly, London W.

\section{NE D E R L A N D.}

\section{DONATEURS.}

De Nederlandsche Handelmaatschappij. | I. D. pRANSEN vaN DE PUTTE, 's Hage. Mr. w. Baron van goltstein, 's Hage. Dr. a. vrolik, Arnhem. P. 's ЈАСOB, Utrecht.

\section{EERELEDEN.}

Prof. Dr. P. J. VETH, Arnhem.

Prof. Dr. J. H. C. KERN, Leiden.

\section{CONTRIBUEERENDE INSTELLINGEN.}

De Bibliotheek van de Universiteit van Amsterdam.

Het Nederlandsch Bijbelgenootschap, te Amsterdam.

Het Nederlandsch Zendelinggenootschap, te Rotterdam.

Het Rijks Ethnographisch Museum te Leiden.

Vereeniging Pomona, te Menado. 


\section{GEWONE LEDEN.}

N. ADRIANI, Utrecht.

Dr. A. T. VAN AKEN, 's Gravenhage.

Jhr. D. $\mathbf{P}$. VAN ALPHEN, 's Gravenhage.

Jhr. E. T. M. vAN ALPHEN, 's Gravenbage.

Jhr. Mr. w. c. A. ALBERDA VAN EKENsTEIN, Groningen.

J. H. vaN BALEN, Nieuwediep.

Prof. Dr. H. BavincK, Kampen.

Mr. W. H. DE BEAUPORT, Leusden.

Jhr. Mr. K. A. GODIN DE BEAUYORT,

's Gravenhage.

N. R. G. M. BäR, 's Gravenhage.

G. W. BEEGER, 's Gravenhage.

H. H. BEELS, Haarlem.

Mr. N. P. VAN DEN BERG, Amsterdam.

Prof. Mr. L. W. c. vaN DEN BERG, Delft.

Mr. W. B. BERgSMa, Apeldoorn.

Mr. G. н. BETZ, 's Gravenhage.

H. H. VAN BEUNINGEN, Utrecht.

w. D. J. BEZEMER, Soest (Prov. Utrecht.)

J. L. BeIJers, Amsterdam.

Mr. А. J. E. BIK, 's Gravenhage.

E. P. т. BIK, 's Gravenhage.

G. BIRNIE, Deventer.

P. A. M. BOELE VAN HENSBROEK, 's Hage. Dr. J. c. Bokrlage, Leiden.

Mr. c. TH. Baron vaN DeN boEtzelaer, Huize Sandwijek bijde Bildt (Utrecht).

J. BoissevanN, Amsterdam.

CH. Boissevain, Amsterdam.

G. M. BoIssevain, Amsterdam.

н. Ј. воог, Leiden.

Jhr. Mr. J. W. G. BOREEL VAN HOGELANDEN, te Velzen.

P. R. Bos, Groningen.

ш. Ј м. воввоом, 's Gravenhage.

P. TEN BOSCH, 's Gravenhage.

H. G. Boumeester, 's Gravenhage.
Mr. W. à BRAKeL ReIGer, 's Hage.

W. G. Bon BRANTSEN VAN DE zIJP, 's Hage.

Jhr. Mr. w. M. DE BRAUW, Middelburg.

J. F. BREIJER, 's Gravenhage.

J. A. VAN DEN BROEK, Delft.

W. D. J. vaN MEETERen brouwer, 's Hage.

M. Buiss, Kwadijk, bij Purmerend.

J. н. DE BUSsy, Amsterdam.

Mr. c. E. J. Graaf van bYLANDT, 's Hage.

Dr. W. CALAND, Breda.

J. P. CAMBIER, Vianen.

H. D. CANNE, 's Gravenhage.

Prof. Dr. D. Chantepie de la SAUSSAYe, Amsterdam.

J. L. CluiJssenaer, Utrecht.

w. A. COBLIJN, Voorburg.

A. cochivs, Amsterdam.

J. н. commiss, 's Gravenhage.

Mr. r. B. CONINCK LIEFsting, 's Hage.

w. COOL, Naarden.

D. Cordes, Amsterdam.

Prof. Mr. P. W. A. CORT VAN DER LINDEN, Amsterdam.

Mr. J. COUPERUs, 's Gravenhage.

J. T. CREMER, 's Gravenhage.

Mr. E. J. J. B. CREMERS, 's Gravenhage.

Mr. R. z. DANNENBARGH, Steenwijk.

G. c. DAUM, 's Gravenhage.

Mr. W. K. Baron VAN DEDEM, Hoorn. W.J.DERX, Zr. Ms. Wachtschip te Batavia.

G. DIEPEN, Roermond.

J. S. A. VAN DISSEL, Delft.

s. C. van DoEsburgh, Leiden.

E. DOUWES DEKKER, 's Gravenhage.

H. c. DoUWes DeKker, Hees bij Nijmegen.

Prof. Mr. H. L. DRUCKER, Leiden.

Mr. L. De Filliettaz bousquet, 's Hage. Dr. r. A. c. DUMontier, 's Gravenhage. 
J. DIJK wz., 's Gravenhage.

p. A. BBBINGE WUBBEN, 's Gravenhage.

c. A. eckstein, 's Gravenhage.

Jhr. Mr. W. c. A. ELOUT VAN SOETERwoude, 's Hage.

- g. emants, 's Gravenhage.

Mr. A. J. VAN EMDEN, 's Gravenhage.

J. ENNEN, Assen.

Mr. J. c. vaN EIJK, Amsterdam.

Jhr. Mr. F. J. J. van EYsingA, Leeuwarden

J. J. P. PANOY, 's Gravenhage. (Sumatrastraat 186).

J. H. FERGUSON, 's Gravenhage.

J. FREYWALd, Parijs (43, rue de Courcelles).

P. G. GEERLING, 's Gravenhage.

w. J. Geertsema, Amsterdam.

Dr. H. D. VAN GELDER, Leiden.

Mr. J. VAN GENNEP, Rotterdam.

Mr. F. H. GöBEL, 's Gravenhage.

Jhr. c. J. L. Goldman, 's Gravenhage.

B. L. GOMPERTZ, Amsterdam.

Prof. J. R. P. P. GONGGRIJP, Delft.

w. R. DE GREVE, 's Gravenhage. CORN'. DE GROOT, 's Gravenhage.

J. H. DE GROOT, 's Gravenhage.

Prof. Dr. J. J. M. DE GROOT, Leiden.

H. D. GUYOT, 's Gravenhage.

s. M. HUGO VAN GIJN, Dordrecht.

Dr. D. DE haAN, Haarlem.

R. E. DE HAAN, Winterswijk.

A. HAGA, 's Gravenhage.

Mr. H. P. L. HaMelberg, Arnhem.

Mr. G. G. VAN HARENCARSPEL, 's Hage.

D. HARTEVRet, Leiden.

w. A. P. N. c. M. HARTManN, 's Hage.

Mr. A. ғ. K. HARTOGH, Amsterdam.

Jhr. c. HARTSEN, 's Gravenhage.

J. J. hasselman, Tiel.

p. L. S. VAN HEEKEREN, Amsterdam.

Mr. J. HEEMSKERK Az., 's Gravenhage.

Mr. A. HeEMSKerk az., Amsterdam.
Mr. J. E. HEEREs, 's Gravenhage. J. J. L. HELDRING, 's Gravenhage. Mr. J. E. HENNY, Amsterdam.

Mr. N. VAN DEN HEUVELL ,'s Gravenhage. J. K. VAN DER HEIJDEN, Bronbeek bij Arnhem.

Mr. J. c. TH. HEYLIGERS, 's Gravenhage. r. HEIJNEN, Oudenbosch.

D. Heiding, 's Gravenhage.

G. H. HINTZEN, Rotterdam.

H. c. HINTZEN, Amsterdam

B. HOETINK.

Dr. J. W. HOPFMANN.

Jhr. H. W. ғ. HORA siccaMa, 's Hage.

J. L. HORDIJK, 's Gravenhage.

J. M. PIJNACKER HORDIJK, 's Gravenhage.

Dr. R. ноRst, Leiden.

P. J. VAN HOUTEN, 's Gravenhage.

Prof. Dr. м. тн. ноштsмa, Utrecht.

J. HUdig DZ., Amsterdam.

P. c. HuIJSER, 's Gravenhage.

H. J. Hidmans, Amsterdam.

M. HiJMans van Wadenoyen, 's Hage.

Mr. A. J. IMMINK, 's Gravenhage.

Mr. в. н. 's ЈАСов, Heiligenberg, Amersfoort.

J. w. JäGER, 's Gravenhage.

J. C. JANSEN, 's Gravenhage.

P. W. JANSSEN, Amsterdam.

Dr. c. W. JANSSEN, Amsterdam.

c. A. J. L. JEEKEL, Huize Dalvoorde, Dedemsvaart.

Dr. F. A. JENTINK, Leiden.

н. н. JUYNBOLL, Leiden.

Prof. Dr. c. M. KAN, Amsterdam.

Jhr. Mr. A. P. c. vAN KARNEBEEK, 's Hage.

Dr. H. ғ. с. TEN KATE Jr., Scheveningen.

c. e. van Kesteren, Brussel.

Mr. L. w. c. Kedchienius, 's Hage.

в. B. KIELSTRA, 's Gravenhage.

Mr. T. H. DER KINDEREN, 's Hage.

H. C. KLINKERT, Leiden. 
Mr. th. A. Kuinkhamer, 's Gravenhage. Mr. p. A. N. s. van medrs, 's Hage. H. F. KOUWENBERG, 's Gravenhage.

F. G. KRAMP, Amsterdam.

J. D. KRUSEMAN, 's Gravenhage.

Prof. Dr. E. F. KRUIJPF, Groningen.

J. A. KRUiJt, Pinang.

J. KUYPER HZN., 's Gravenhage.

A. H. KUIPERs, Haarlem.

G. A. DE LANGE, 's Gravenhage.

c. J. LEENDERTZ, Leiden.

W. H. VAN LEEUWEN, Amsterdam.

c. LELY, 's Gravenhage.

C. H. M. LE ROUX.

Mr. J. A. LEVY, Amsterdam.

Mr. H. D. LEvYssohn NoRMan, 's Hage.

J. H. LIEFTINCK, Amsterdam.

Mr. JAC. LION, 's.Gravenhage.

Prof. Dr. G. A. F. MOLENGRAafF, Amsterdam.

A. Е. MOLL, 's Gravenhage.

Dr. к. ш. м. моNтілN, Schiedam.

A. E. MOOYAART, 's Gravenhage.

H. MULLER SZN, Rotterdam.

HENDRIK P. N. MULLER, Rotterdam.

Mr. a. van naAmen van eEmnes, 's Hage.

Mr. s. H. NEDERBURGH, 's Gravenhage:

J. R. H. NEERVOORT VAN DE POLL,

Amsterdam.

Mr. H. A. A. NEYs, 's Gravenhage.

P. M. NETSCHER, 's Gravenhage.

c. VAN DER GON NETSCHER.

Prof. G. K. NIEMANn, Delft.

J. VAN NIEUWKUIJK, 's Gravenhage.

Mr. o. J. H. Graaf van LIMBURG STIRUM, 's Gravenhage.

Mr. A. LIND, Amsterdam.

Mr. H. о. VAN DER LINDEN, Dordrecht.

Prof. Mr. P. A. VAN DER LITH, Leiden. Dr. TH. W. vaN LITH DE JEUde, Leiden.

Prof. Jhr. Mr. W. H. DE SAvornin Lohman, Amsterdam.

Prof. Mr. J. DE LOUTER, Utrecht. G. P. LUCARDIE, 's Gravenhage.

Mr. R. MaCalester loup, 's Gravenhage.

Mr. H. L. M. LUDEN, Amsterdam.

Mr. R. MELVIL Baron VAN LIJNDEN,

Utrecht.

Mr. ․ B. Baron Mackay, 's Gravenhage.

Mr. J. c. DE MAREZ OYENS, 's Gravenhage.

Prof. Dr. к. martin, Leiden.

Mr. M. Massink, Amsterdam.

Dr. в. F. Matthes, 's Gravenhage.

Mr. F. Alting mees, Amsterdam.

A. Mellink, 's Gravenhage.

Jhr. Mr. a. L. J. Melvill van carnbée,

's Gravenhage.

Dr. J. Mendels, Delft.

AUGUST MESRITZ, Amsterdam.

Jhr. Mr. o. E. van NISPEN, 's Hage.

M. NIJHOFF, 's Gravenhage.

A. J. NIJLAND, Utrecht.

H. A. DE Nooy, 's Gravenhage.

Mr. o. w. star noman, 's Gravenhage.

A. P. M. VAN OORDT, Leiden.

A. oltmans, 's Gravenhage.

J. D. OORTMAN GERLINGS, Utrecht.

Mr. M. H. c. van oosterzee, 's Hage.

Pruf. Mr. J. OPPENheIM, Groningen.

Mr. A. M. oudemans, Nijmegen.

Mr. D. L. P. DE PAULY, 's Gravenhage.

Dr. H. PEELEN, Scheveningen.

Prof. Dr. c. a. Pekelharing, Utrecht.

M. т. H. PERELAER, 's Gravenhage.

Mr. N. G. PIERson, 's Gravenhage.

Prof. Dr. A. PIERson, Amsterdam.

H. D. PIERson, 's Gravenhage.

Prof. c. Poensen, Delft.

Prof. Dr. J. PIJNAPPEL GZN., Middelburg.

Mr. M. J. PIJNAPPEL, Amsterdam.

Dr. w. PLEyte, Leiden.

c. W. PLeyte WzN., Amsterdam.

a. s. pransen van de pUtte, Arnhem.

G. A. van PUtTEN, 's Gravenhage. 
Jhr. Mr. J. K. W. QUaRLes van UfFord, JOH. F. SNelleman, Rotterdam.

's Gravenhage.

c. J. w. Ramann, Amsterdam.

Mr. W. J. SNOUCK HURGRONJE, 's Hage.

M. A. VAN RHEDE VAN DER KLOOT, 's Hage.

Jhr. Mr. G. C. J. VAN REENEN, 's Hage.

R. REINDERS, Willemsoord.

Mr. W. J. VAN WELDEREN Baron RENGERS, Leeuwarden.

Jhr. Mr. J. c. REYNST, 's Hage.

Dr. J. G. F. RIEDEL, Brussel, 51, Rue de la Régence.

Jhr. Mr. TH. H. F. VAN RIEMSDIJK, 's Gravenhage.

A. soL, 's Gravenhage.

Dr. w. N. DU RIEU, Leiden.

Jhr. Mr. J. ROËLL, 's Gravenhage.

Dr. L. W. G. DE ROo, Nijmegen.

G. P. Rodpraer, Amsterdam.

G. Baron rosenthal, Amsterdam.

J. W. Roskes, Rotterdam.

Mr. J. v. J. ROOYAARDS VAN DEN HAM,

Utrecht.

WILLEM RUYS, Rotterdam.

Dr. E. VAN RIJCKEVoRsel, Rotterdam.

ED. VON SAHER, Haarlem.

J. L. P. SANDERS, Leiden.

Mr. A. W. J. PARNCOMBE SANDERS, 's Hage.

R. A. VAN SANDICK, Deventer.

Mr. J. C. J. vAN DER SCHALK, NoordwijkBinnen.

J. E. N. Baron SCHMMMELPENNINCK vAN DER OIJE, 's Gravenhage.

Prof. Dr. g. Schleget, Leiden.

w. м. н. vON SCHMID, 's Gravenhage.

c. w. R. scholten Jr., Amsterdam.

N. D. schUURMans, Haarlem.

Dr. J. skmmbink, 's Gravenhage.

a. M. Servatius, Terwolde bij Deventer.

Mr. c. J. sICKEsz, 's Gravenhage.

J. H. J. SIGAL, 's Gravenhage.

J. G. SLLEM, Amsterdam.

н. јон. sMTD, Dennenoord, Laren.

A. J. SPAAN, 's Gravenhage.

H. SPAKLER, Amsterdam.

Prof. J. SPanjaARd, Delft.

Prof. Dr. J. s. SPEIJER, Groningen.

Mr. J. P. SPRENGER VAN EIJK, 's Hage.

E. A. Staël van holstein van vloten,

Arnilem.

H. T. VAN STEEdEN, 's Gravenhage.

s. R. STEINMETZ, Leiden.

c. м. F. STOCKHAUSEN, Utrecht.

w. P. VAN stockUM JR., 's Gravenhage.

N. P. VAN DER STOK, 's Gravenhage.

Dr. J. A. VAN DER STOK, Venlo.

А. м. Н. J. stokvis, 's Gravenbage.

P. DE STOPPELAAR, Leiden.

F. L. K. STORM VAN 'S GRAVESANDE, 's Gravenhage.

Mr. Th. stuart, Amsterdam.

Jhr. Mr. v. DE stuers, 's Gravenhage.

Jhr. Mr. H. DE stuers, 's Gravenhage.

Jhr. Mr. J. E. DE sturLer, 's Hage.

Prof. Dr. W. F. G. sURINGar, Leiden.

Jhr. Mr. J. H. T. K. VAN SWINDEREN,

Huize Rijs, Balk, gem. Gaasterland.

A. W. sisthoff, Leiden.

Mr. J. P. R. TAK VAN POORTVLIET,

's Gravenhage.

P. E. tegenberg, Amsterdam.

Dr. W. A. TERWOGT, Hoorn.

M. Teixeira de mattos, Amsterdam.

Mr. A. telting, 's Gravenhage.

Jhr. Mr. c. J. DEN TEx, Amsterdam.

Mr. c. TH. T. THURKOW, 's Gravenhage.

Mr. G. VAN TIENHOVEN, 's Gravenhage.

P. F. LAGING tobias, Nijmegen.

Dr. номмо TONKEs, Arnhem.

P. W. M. TRAP, Leiden.

J. P. TRAP, Leiden.

P. Twiss, 's Gravenhage. 
c. E. UHLENBECK, Willemsoord.

Mr. ғ. c. vaLCK, Gravenhage.

Prof. Dr. J. J. P. valeton, Amersfoort. Mr. H. A. VAN dE velde, Loosduinen.

Mr: s. A. VENING MeINesz, Amsterdam.

Dr. P. J. F. VERMEUlen, Amsterdam.

Mr. W. A. BARON VAN VERSCHUER,

's Gravenhage.

Mr. J. A. DE vICQ, Melbourne.

Jhr. G. G. DE "villeneuve, 's Hage.

T. P. VIRULY, Leiden.

L. DE vlaming, Haarlem.

J. M. VAN vLEUTEN, 's Gravenhage.

C. A. M. VAN vLIET, 's Gravenhage.

Dr. W. r. van vLIET, Delft.

Mr. W. van DER viret, Amsterdam.

Dr. G. VAN VLOTEN, Leiden.

Prof. Mr. W. van DER vLUgt, Leiden.

B. R. P. VAN VLIJMEN, 's Gravenhage.

Mr. J. A. G. Baron DE vos VAN STEEnWIJK, Brummen.

E. J. voute, Zeist.

Mr. c. voute, 's Gravenhage.

Prof. A. C. VReEde, Leiden.

p. A. vriese, Amsterdam.

P. T. vRIESENDorP, 's Graven hage.

E. DE WAAL, 's Gravenhage.
Mr. A. F. vos dE WAEL, Zwolle. C B. VAN DE WAL, Amsterdam.

J. WALLAND, 's Gravenhage.

M. J. WAller, Amsterdam.

Prof. Dr. Max weber, Amsterdam.

Mr. o. J. E. Baron vaN WASSENAER vaN CATWIJck, 's Gravenhage.

A. E. WASZKLEWICZ, 's Gravenhage.

A. W. P. WEITZEL, 's Gravenhage.

A. C. WERTHEIM, Amsterdum.

Mr. м. Р. H. wrencX, 's Gravenhage.

F. W. WIEsEMaN, 's Gravenhage.

J. W. wilsov, Amsterdam.

Dr. c. WINKLER, Utrecht.

M. H. Witbols PEUGEN.

W. P. WOLterbeEK, Amsterdam.

A. WUNderly, Parijs.

J. wüste, Amsterdam.

Jhr. Mr. H. VAN DER WIJCK, 's Hage.

Jhr. c. VAN DER WIJCK, 's Hage.

L. ॐ. vaN WIJK, Amsterdam.

Dr. тH. CH. L. WiJnMalen, 's Hage.

WHLLM wIJT, Rotterdam.

JоH. LKEMA, 's Gravenhage.

J. W. IJZERMAN, 's Gravenhage.

Mr. H. zillesen, 's Gravenhage.

G. E. V. L. VAN ZUYLEN, 's Gravenhage.

CORRESPONDEERENDE LEDEN.

5. C. NEURDENBURG, Rotterdam.

J. D. ₹. schmeltz, Leiden.

H. sundermanN, Mörs, Rijn-Pruissen. 


\section{NEDERLANDSCH OOST- EN WEST-INDIË.}

Z. Exc. Mr. c. PIJNACKER HORDIJK, Gouverneur-Generaal van N.-Indië, Donateur.

\section{GEWONE LEDEN.}

Mr. J. н. abendanon, Secretaris van het Dep. van Onderwijs, Eeredienst en Nijverheid, te Batavia.

G. N. vaN ALPHeN de veER, $1^{\text {e }}$ Luit.-Adjudant van den Chef van het wapen der infanferie te Batavia.

H. altmann, Controleur 2e kl. bij het B. B. Tjilegon, Bantam.

D. н. ANDEWEG, Assistent-resident van Tjaringin (Bantam).

J. н. АNschuTz, Officier van gezondheid te Paja Combo (Sum. Westkust.)

Jhr. Mr. T. A. J. vaN asCH vaN wIJCK, Gouverneur van Suriname, Paramaribo. L. А. вАкнUIs, le Luit. der Infanterie, gedetacheerd bij de triangulatiebrigade ter Sumatra's Westkust.

J. Bensbach, Resident van Ternate.

Mr. G. J. A. vaN BERCKEL, Lid van den Raad van Justitie te Semarang.

Mr. J. H. Bergsma, Lid in den Raad van Indië, Batavia.

G. P. A. вIschopr, Asp.-controleur te Tjiandjoer in de Preanger-Regentschappen.

w. c. BLANKEN, Asp.-controleur bij het Binn. Bestuur, tijd. toegevoegd aan den Inspecteur van cultures in de Preanger-Regentschappen, te Bandoeng. Dr. н. J. вовLMan, te Djokjokarta.

Mr, н. Ј. воOL, te Deli.

CH. P. BOREL, Aspirant-controleur, toegevoegd aan den ass.-resident van Djoewana.

н. ш. воSмaN, Hoofd-onderwijzer aan de kweekschool voor inl. onderwijzers, te Makasser.

D. P. VAN BRAAM MORRIS, Gouverneur van Celebes en Onderhoorigheden, te Macasser.

Dr. J. L. A. BRANDEs, Ambtenaar voor de beoefening der Inlandsche talen, Commissaris van het Institunt, Batavia.

J. A. н. BReiJMann, Controleur le klasse te Tandjoeng Radja (afdeeling Ogan en Komering Ilir en Blidah (Palembang).

J. W. vaN DEN BRoEk, Kapitein der Infanterie te Telok Betong.

G. P. DE BRUIJN KOPS, Secretaris, Amboina.

Dr. w. BURCK, Adj. Directeur van 's Lands Plantentuin, te Buitenzorg.

Dr. DAVID R. CAPRILEs, Geneesheer te Curaçao.

H. A. N. Caterius, Luit.-kol. der Infanterie te Atjeb.

н. м. La chapelie, Referendaris hij de Algemeene Secretarie te Buitenzorg. 
w. p. van charante, President van het Liefdadigheids-gesticht enz. te Depok (Buitenzorg).

Mr. J. A. VAN DER CHIJs, Rijks-Archivaris, Batavia.

w. G a. c. Christian, Kapitein O.-I. Leger. Serang (Bantam.)

Mons. A. c. Claessens, Aartsbisschop van Sirace, apostolisch vicaris en pastoor van Batavia.

Mr. J. w. th. cohen stuart, Referendaris ter Alg. Secretarie, Buitenzorg.

Mr. W. A. J. VAN DAvelaAR, Leeraar in de geschiedenis, land- en volk. van

N. I. aan het Gymnasium Willem III, Batavia.

K. P. VAN DELDEN-LAËRNe, Assistent-resident van Trenggalek, res. Kediri.

J. A. vaN DELDEN, Lid van de firma Reynst \& Vinju, te Batavia.

TH. DELPRAT, Ingenieur le klasse bij de Staatsspoorwegen, Sumatra's Westkust, Solok.

Mr. c. TH. vaN DEVENTER, Advocaat te Semarang.

c. DEIJKkrhorp, Kolonel, Civiel en Milit. Gouverneur van Atjeh en Onderhoorigheden, Kota Radja.

J. A. DEZENTJE, Landhuurder, Ampal, residentie Soerakarta.

H. Dokpr, Controleur 2e kl. te Segeri (Celebes).

M. C. VAN DOORN, Kapitein-luitenant ter zee, Batavia.

J. P. vaN DRIEst, Controleur le kl. te Moeara Enim (Palembang.)

EUg. DUBoIs, Officier van Gezondheid, te Toeloeng Agoeng, Java.

P. A. L. E. VAN DIJK, Controleur le klasse te Lagoeboti, onderafd. Toba, res. Tapanoeli.

A. J. A. F. ERRDMans, Secretaris voor de inlandsche zaken, Makasser.

Dr. A. VAN DER ELST, Officier v. gezondheid te Semarang.

Mr. W. A. engelbrecet, Directeur van het Depart. v. Justitie, te Batavia.

H. E. D. engelHard, Ass.-resident van Montrado.

к. т. ENGelbert van Bevervoorde, le Luitenant-adjudant van den mil Commandant van Sumatra's Oostkust te Medan (Deli).

M. VAN DER ENT, Controleur 2e kl. op non-activiteit, te Batavia.

J. PH. ermeling, Vertegenwoordiger in Ned. Indië der Billiton-Maatschappij, Buitenzorg.

Mr. W. J. essers, Raadsheer in het Hooggerechtshof van N. I., Batavia.

I. PAEs, oud-Resident, Soekaboemi.

P. FOKKENS JR., Inspecteur der Cultures, toegevoegd aan den Directeur van Binnenl. Bestuur, enz., te Batavia.

A. H. G. FOKKER, President van de Factory der Ned. Handelmaatschappij, Batavia.

R. FENNEMa, Ingenieur $1^{\mathrm{e}}$ klasse te Buitenzorg.

Mr. W. PRANÇIS, Voorzitter van de landraden te Poerworedjo en Koetoardjo. Mr. W. DE GELDER, Procureur-Generaal bij het Hooggerechtshof van N. I., te Batavia. 5 e Volgr. VII. 
w. vAN GELDER, Hoofdonderwijzer aan de school voor zonen van inlandsche hoofden te Tondano (Menado).

J. L. van Gennep, Controleur le kl. te Probolinggo.

D. GERTH VAN WIJK, Leeraar in de Maleische taal aan het Gymnasium Willem III, te Batavia.

G. P. H. H. GONGGRIJP, Algemeen ontvanger, Batavia.

N. GRaApland, tijd. Schoolopziener inl. onderwijs, Tondano (Menado.)

D. GRIVEL, Hoofdonderwijzer aan de kweekschool voor inlandsche onderwijzers te Fort de Kock (Padangsche Bovenlanden).

w. P. GROENEVELDT, Lid in den Ratad van N.-I, Batavia.

D. GROENEVELD, Directeur der Javasche Bank, te Batavia.

Dr. J. GRoneman, Geneesheer te Indramajoe.

H. J. DE GROOT, Controleur 2e klasse in de afd. Zuiderdistricten, Gouv. Celebes.

Dr. J. G. н. GunNing, Ambtenaar voor de beoefening der Inlandsche talen, tijdelijk belast met geven van onderwijs in de Jav. taal aan het Gymn. Willem III, te Batavia.

Dr. c. Gutteling, Eerste Stadsgeneesheer, Batavia.

Mr. J. A. ваAKMAN, Redacteur Bat. Handelsblad, Batavia.

c. J. vaN haAstert, Hoofdonderwijzer aan de kweekschool voor inl. onderwijzers, te Bandoeng.

J. наввема, Inspecteur van het inlandsch onderwijs, Batavia.

Dr. B. HAGEN, Geneesheer te Laboean Deli.

L. K. HARMSEN, Hoofdonderwijzer aan de kweekschool voor inl. ouderwijzers te Padang Sidempoean.

G. A. Hansen, Kapitein der Infanterie te Batavia.

J. P. C. Hartevelt, Inspecteur van Financiën, te Pasoeroean.

A. L. van hasselt, Resident van Tapanoeli (Sumatra's Westkust), Padang Sidenpoean.

G. P. L. нцUёт, Gezaghebher 2e klasse bij de Gouvernements-marine a/b. van het stoomschip Raaf, Bandjermasin.

H. D. helderman, Contr 2e kl. te Batang Taro (resie Tapanoeli.)

o. L. Helfrich, Controleur 2e klasse in de afd. Mana en Pasoemah Oeloe Mana, res. Benkoelen.

J. VAN HENGEL, Controleur 2e kl. te Siak (Sum. Oostk.)

J. VAN HENGST, Landhuurder te Buitenzorg.

G. w. w. c. Baron vaN HоËveLL, Resident van Amboina.

aLPн. н. А. м. нонмаN, Opnemer bij de inigatie-werken, Indramajoe (Cheribon.)

w. c. Hoogkamer, Resident van Timor en Onderhoorigheden, te Koepang.

w. новzоо, Zendeling, Semarang.

K. F. HoLLe, Adviseur-honorair voor inlaudsche zaken, Buitenzorg.

м. н. ноUтKAMP, Alg. Ontranger van 's Lands kas te Bandoeng. 
J. c. Keller van hoorn, Controleur 2e klasse te Bandoeng, res. PreangerRegentschappen.

Dr. D. W. HORST, Assistent-resident, Sambas.

G. F. K. VAN HULS, Asp.-controleur bij het B. B. te Kendal (Semarang).

H. A. hiJMans van anrooy, laatst Secretaris van de Oostkust van Sumatra.

Dr. Jul. Jaсoвs, Officier van Gezondheid, Atjeh.

E. J. к. G. Jacobson, Pangkallan (Berendan), afd. Langkat, Oostk. Sumatra.

A. м. Jokkes, Resident Z. en O. afd. van Borneo, Bandjermassin.

Mr. Dr. J. c. G. Jonker, Ambtenaar voor de Inlandsche talen, Makasser.

c. vAN Kerckhofr, Controleur 2e kl. op non-activiteit, te Batavia.

P. K. W. Kern, Asp. controleur, Ponorogo (Madioen).

E. A. KLerks, Controleur le klasse te Benkoelen.

L. KNAPPERT, Controleur $2^{\mathrm{e}} \mathrm{kl}$., Soepajang, afd. XIII en IX Kota (Pad. Bovenlanden).

P. J. Kooreman, Assistent-resident van de afdeeling Painan, Sumatra's Westkust.

G. J. VAN KOOTEN, Kapitein-adjudant van den commandant van het leger, Batavia.

Jhr. w. н. w. ре коск, Adjunct-inspecteur van Financiën, te Semarang.

J. c. тH. Kroesen, Resident van Soerabaja.

R. c. krofsen, Vice-president van den Raad van N.-I., Batavia.

c. A. Kroesen, Controleur le klasse in de onderafd. Boven Langkat (Bindjei), Sumatra's Oostkust.

J. A. Kroesen, Controleur in de afd. Batoe Bara, Laboean Roekoe, Sumatra's Oostkust.

J. c. KUMmer, gepensionneerd Adj. Insp. Inl. onderwijs te Magelang, res. Kedoe.

Mr. A. C. p. Lammers van toorenburg, Lid van den Raad van Justitie te Semarang.

к. ғ. H. VAN LANGEN, Resident van Benkoelen.

F. A. LIEPRINCK, Inspecteur der cultures, toegevoegd aan de Directeur van Binnenl. Bestuur, Batavia.

Dr. W. VAN LINGen, Predikant te Semarang.

D. F. W. LUCassen, Suikerfabrikant, te Doekoeh Wungin, Tegal.

r. E. LUITJEs, Hoofdonderwijzer aan de kweekschool voor inlandsche onderwijzers te Amboina.

Mr. c. W. Margadant, Leeraar aan de afd. Indische taal-, land- en volkenkunde van het gymnasium Willem III, Batavia.

H. L. C. TE MECHELEN, Hoofdinspecteur voor de opiumaangelegenheden, Rembang.

Mr. J. н. мeIss, Voorzitter van den landraad te Indrawajoe (Cheribon).

J. J. MEIJER, laatst Controleur te Goenoeng Kentjana (Bantam) op nonaktiviteit te Buitenzorg. 
w. MEIJER, Hoofdonderwijzer aan de school voor zonen van Inlandsche hoofden te Magelang (Kedoe.)

J. E. DE MEIJIRR, Hoofd-Ingenieur $2 \mathrm{e}$ kl. b/d Waterstaat en B. O. W. in N. I., Batavia.

Mr. CH. vaN MEURs, Griffier bij het Hof van Justitie, Commissaris voor Suriname, te Paramaribo.

w. J. M. MiCHIBLSEN, Resident van Sumatra's Oostkust, Medan.

A. H. MOORREes, Asst-Resident van Siboga, Sum. Westkust.

o. M. DE MUNNICK, Gouverneur van Sumatra's Westkust, Padang.

J. в. Neumann, Controleur le klasse in de onderafdeeling Ommelanden van Padang (Loeboeg Begaloeng), Sumatra's Westkust.

w. c. NieuwenhuIJzen, Majoor der Infanterie, te Atjeh.

J. P. NIKs, Hulpprediker te Babauw, (Timor, standplaats Koepang).

Dr. J. c. c. W. vaN NoOTEN, Leeraar in de wis- en natuurkunde aan de Hoogere Burgerschool te Soerabaja.

J. B. VAN DER HOUVEN VAN OORDT, Ambtenaar voor den Burgerlijken dienst te Buitenzorg.

G. oostergeter, laatstelijk Hoofdonderwijzer aan de kweekschool voor inl. onderwijzers Bandjermasin, op non-aktiviteit.

c. A. vaN OPHUIJSEN, Adjunct-Inspecteur van het Inlandsch onderwijs te Fort de Kock.

T. OTTOLANDER, Sitoebondo.

G. J. oudemans, Controleur 2e klasse, Djokjakarta.

c. oudemans, Djokjakarta.

J. PEELEN, Asst-Rest Martapoera (Z. en O. afd. Borneo).

Mr. M. c. PIEPERs, Raadsheer in het Hoog-Gerechtshof, Batavia.

Jhr. p. POMPE vaN MEERDERvoorT, laatst Civ. en Mil. Gouverneur van Atjeh en Onderhoorigheden.

H. E. PRINs, Assistent-resident voor de politie, te Padang.

P. н. J. PRIVÉ, Aspirant-controleur in de residentie Preanger Regentschappen.

A. PRUIJS VAN DER HOEVEN, Lid in den Raad van Nederl. Indië, Batavia. RADEN TOEMENGgOENG ARIO Noto DININGRAT, Regent van Malang.

J. P. H. van RALDShoven, Controleur le klasse te Manindjoe (Padangsche Bovenlanden).

RADEN MAS ISMANGOEN DANOE WINOTO, Adjunct-inspecteur van het Inlandsch onderwijs, Probolinggo.

RADEN MAS TOEMENGgOENG PANDJ ADININGRAT, Regent van Demak.

H. J. A. RAEDt van oldenbarnevelt, Controleur $2^{\mathrm{e}}$ klasse, tevens Politiek agent te Djambi.

G. P. A. RENAUD, Hoofd-Ingenieur le klasse, b/h mijnwezen te Batavia.

L. c. A. Rombach, Kolonel, chef van den geneesk. dienst in N.-I. Batavia, 
Mr. D. W. K. DE Roo DE LA PallLe, Ambtenaar bij het Departement van Justitie, Batavia.

P. DE roo dE LA paILle, Aspirant-Controleur te Tjitjalengka (PreangerRegentschappen).

J. т. DE RooIJ, Controleur le kl. ter Westkust van Sumatra.

в. J. в. Rоsкотт, Assistent-resident van Tebing Tinggi, res. Palembang.

J. A. VAN RIJN vaN ALKEMade, Secretaris der residentie Oostkust van Sumatra, te Medan.

P. J. van santen, Pastoor te Batavia.

J. SCHEel, Controleur 2e kl. in de resie Cheribon.

G. A. Scherer, Resident van de Padangsche Bovenlanden, Fort de Kock.

H. w. scheuer, Kapitein der Genie (tijdel. mijn-ingenieur) te Soengeihiat (Banka).

D. м. J. schipr, Controleur 2e klasse, afd. Mokko Mokko, Benkoelen.

P. G. schmidhamer, le Luit. bij het $3^{\mathrm{e}}$ depot-bataillon der Infanterie, Malang. w. A. SCHNEIDER, Luit.-kolonel, der Infanterie te Batavia.

J. G. sснот, Controleur le kl. te Asahan, (Sum. Oostk.)

J. J. F. SCHREUEL, Controleur le klasse te Sipoetih (Lampong).

K. L. VAN SchodWenborg, Directeur der hoogere burgerschool, Samarang.

J. A. SCHRöDER, gewezen Hoofdagent der N. I. Stoomvaartmaatschappij, Buitenzorg.

L. P. tUIJL schUitemaker, Hoofdonderwijzer aan de kweekschool voor inl. onderwijzers, te Probolinggo.

J. ғ. н. schultz, Adsistent-resident van de afdeeling Tebing Tinggi. (Palembang).

w. N. SENN van baSEL, te Tjikadoe (Onderneming Tjikadoe Tjikapas).

g. sieburgh, Controleur der le klasse in de ond.-afd. Medan, Oostkust van Sumatra.

Dr. c. SNodck HURgronse, Adviseur voor Oostersche talen en Mohammedaansch recht, Batavia.

E. P. C. sol, Lid der Algemeene Rekenkamer, te Batavia.

H. VAN STEEDEN, Ass.-resident te Soerakarta.

J. w. stempoort, Luit. Kolonel der Infanterie te Meester Cornelis (Batavia). Dr. J. P. VAN DER STOK, Directeur van het Observatorium te Batavia.

A. P. stoonvoger, Controleur 2e klasse te Goenoeng Kentjana, afd. Lebak, in de residentie Bantam.

J. stormer, Controleur le klasse, te Batjan.

N. J. STRUICK DU MoULIN, Inspecteur van Financiën in de IVe afd. te Soerabaja.

H. N. STUART, Tolk voor de Chineesche taal, Pontianak (Wester-afd. van Borneo).

ש. C. BARON SWEERTS DE LANDAS WIJBORgh, Algemeene Secretaris, Buitenzorg.

TJOA DJIEN SING, Kapitein der Chineezen, te Soerabaja.

Dr. M. TREUB, Directeur van 's Lands Plantentuin, te Buitenzorg.

s. w. TroMP, Resident van de Westerafd. Borneo, Pontianak. 
w. L. troostenburg de bruijn, Controleur 2e klasse in de onderafdeeling Alahan Pandjan, afd. XIII en IX Kota (Padangsche Bovenlanden).

H. J. TYDeMan, Resident van Tegal.

D. P. UHLENBEcK, Secr. van het Gouv., Buitenzorg.

н. тн. Ј. Uлтттввоовск, 2е Onderwijzer aan de kweekschool voor inl. onderwijzers, te Probolinggo.

Mr. A. w. c. verweIs, President van den Raad van Justitie, Makasser.

J. DE vOGEL, Asp. Controleur, Preanger Regentschappen.

L. M. vonck, Controleur $2^{\text {e }}$ klasse te Sekajoe, res. Palembang.

w. voorthuYzen. le Onderwijzer aan de Kweekschool voor inl. onderwijzers, te Bandoeng.

P. voute, Samarang.

Dr. A. G. vorderman, Inspecteur van den burgerl. geneesk. dienst voor Java, en Madoera, te Batavia.

w. H. vRiJbUrG vaN DER hell, Controleur der $2^{e}$ klasse in de contrôle-afd. Wirosari, afd. Grobogan (Semarang).

G. DE WAAL, Controleur le kl. in de res. Westerafd. van Borneo.

L. VAN WEELDEREN, aspirant-Controleur in de res. Soerabaja, toegevoegd aan den Assistent-resident van Lamongan.

c. w. J. Wenneker, Pastoor, Soerabaja.

c. J. Westenberg, Controleur 2e klasse te Medam.

Mr. w. A. P. p. L. WINCKEL, Officier van Justitie bij den Raad van Justitie te Makasser.

M. WILLEMSTIJN, Kolonel-intendant, Batavia.

Jhr. 0. VAN DER WIJCK, Secretaris van het Gouvernement, Buitenzorg.

s. B. zeverisn, President der Jav. Bank, Batavia.

B. vaN zUTPHEN, oud-Resident van Bali en Lombok, Soerabaja.

w. E. vaN zUTPHEN, Aspirant-Controleur te Indramajoe.

A. H. B. ZWAGER, Secretaris van den Raad van Indië, Commissaris van het Instituut, Batavia.

T. J. A. VAN ziJll DE JONG, Luitenant-Generaal, Commandant van het leger en Chef van het Dep. van Oorlog, Batavia. 


\title{
L IJ S T
}

D E R

\section{BINNEN- EN BUITENLANDSCHE ACADEMIËN, GELEERDE GENOOTSCHAPPEN EN INSTELLINGEN,}

\begin{abstract}
WAARMEDE HET KONINKLIJK INSTITUUT DOOR RUILING DER IITGEGEVEN
\end{abstract}
WERKEN IN VERBINDING IS.

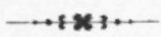

\section{NEDERLAND.}

Koninklijke Akademie van Wetenschappen, te Amsterdam.

Bibliotheek van de Universiteit van Amsterdam.

Kon. Nederl. Aardrijkskundig Genootschap, te Amsterdam. (Adres: Bibliotheek Gen. Universiteit, Singel.)

Vereeniging voor de Statistiek in Nederland, te Amsterdam.

Nederlandsch Bijbelgenootschap, te Amsterdam.

Redactie van het Tijdschrift „De Rijnsche Zending. Tijdschrift ter hevordering van het Christendom in Nederlandsch-Indië" (Adres: de heer J. P. G Westhoff, Amsterdam.)

Redactie van de „Indische Mercuur”, Amsterdam. (Rokin 60.)

Nederlandsche Maatschappij ter bevordering van Nijverheid, te Haarlem.

Teyler's Genootschap, Haarlem.

Bibliotheek der Rijks-Universiteit, te Leiden.

Rijks Ethnographisch Museum te Leiden

Maatschappij der Nederlandsche Letterkunde, te Leiden.

Koninklijke Bibliotheek, te 's Gravenhage.

Bibliotheek van het Ministerie van Waterstaat, Handel en Nijverheid, te 's Gravenhage.

Bıbliotheek van het Ministerie van Koloniën, te 's Gravenhage.

Koninklijk Instituut van Ingenieurs, te 's Gravenhage.

Indisch Genootschap, te 's Gravenhage.

Instelling van onderwijs in de taal-, land- en volkenkunde van Ned.-Indië, te Delft. Historisch Genootschap, gevestigd te Utrecht.

Utrechtsche Zendingsvereeniging, te Utrecht.

Nederlandsch Zendelinggenootschap (Director Dr. J. C. Neurdenburg), te Rotterdam.

Nederlandsche Zendingsvereeniging, „Schooneberg”, West-Zeedijk, te Rotterdam.

Redactie van het „Nederlandsch Zendingstijdschrift”. (Redacteur: P. van Wijk Jr. Luth. Pred. te Rotterdam). 


\section{OOST-INDIË.}

Bataviaasch Genootschap van Kunsten en Wetenschappen, te Batavia.

Koninklijke Natuurkundige Vereeniging in Nederl.-Indië, te Batavia.

Vereeniging tot bevordering der geneeskundige wetenschappen in Nederlandsch-Indië, te Batavia.

Koninklijk Instituut van Ingenieurs, afd. Nederl.-Indië, te Batavia.

Nederlandsch-Indische Maatschappij van Nijverheid en Landbouw te Batavia. Vereeniging voor oudheid-, land-, taal- en volkenkunde te Djokjokarta.

Redactie van het Indisch Militair Tijdschrift, te Batavia. Redactie: H. P. Willemstijn.

Bibliotheek van de Algemeene Secretarie, Batavia.

\section{BELGIË.}

Académie Royale des Sciences, des Lettres et des Beaux-Arts de Belgique, te Brussel. (Palais des Académies.)

Société Royale Belge de géographie, te Brussel. (171, Rue Potagère.)

Société scientifique, Louvain (rue des Récollets 11.)

Société de géographie d'Anvers, te Antwerpen.

\section{FRANKRIJK.}

Société Asiatique, Parijs, 1, Rue de Seine. (Palais de l'Institut.)

Société de géographie de Paris, te Parijs (Boulevard Saint- Germain, 184).

Société d'ethnographie, te Parijs.

Société Académique Indo-Chinoise, te Parijs.

Société des études Japonaises, Chinoises, Tartares et Indo-Chinoises, te Parijs. Société des études coloniales et maritimes, te Parijs.

Musénm d'histoire naturelle, te Parijs.

École spéciale des langues Orientales vivantes, te Parijs.

Société de géographie commerciale de Bordeaux, te Bordeaux.

Société de géographie de Lyon, te Lyon.

Musée Guimet, 30 Avenue du Trocadéro, Parijs.

Union géographique du Nord de la France, te Douai.

Société normande de géographie, te Rouaan.

Société de géographie de Tours, te Tours (Indre et Loire). (Adres : Secrétaire général, Rue Etienne-Pallu, 25, à Tours).

Société de géographie et d'archéologie de la province d'Oran.

\section{SPANJE EN PORTUGAL.}

Sociedad geográfica de Madrid, te Madrid (Calle del Leon 21.)

Sociedade de geographia de Lisboa, te Lissabon.

Real Academia de Ciencias de Lisboa, te Lissabon.

ITALIË.

Reale Accademia dei Lincei, te Rome. 
Reale Istituto Jombardo di Scienze e Lettere, te Milaan. Mr. Uochli. Museo civico di storia naturali di Genova, te Genua.

Redactie van het Tijdsehrift Cosmos. (Redacteur Guido Cora.) Turijn.

Société Asiatique Italieune, Florence.

Societa Africana d'Italia. Napoli. Vin Medina 63.

\section{RUSLAND, ZWEDEN EN NOORWEGEN.}

Académie Impériale des Sciences, te St. Petersburg.

Société Impériale géogruphique de Russie, te St. Petersburg.

Bibliothèque de l'Université Royale de Norvège, à Christiania.

\section{ZWITSERLAND, DUITSCHLAND, OOSTENRIJK.}

Société Neuchâteloise de Géographie (Suisse), Locle.

Geographisehe Gesellschaft von Bern, te Bern.

Königlich Prenssische Akademie der Wissenschaften, te Berlijn.

General-verwaltung der Königlichen Museen, te Berlijn.

Hydrographisehes Amt der Kaiserlichen Admiralität, Berlijn, W. Matthäikirebstrasse $\mathrm{n}^{0}, 9$.

Berliner Gesellschaft für Anthropologie; Ethnologie und Urgeschichte, te Berlijn (Königgrätzer

Gesellschaft für Erdkunde, te Berlijn (Zimmerstrasse 90 Berlin S. W.)

Deutscher Kolonialverein, Berlijn S. W., Markgrafenstrasse 25 (Redaktion der Deutschen Kolonialzeitung.)

Geographische Gesellschaft in Bremen (Mendesstrasse 8).

Verein für Erdkunde, te Dresden.

Verein für Geographie und Statistik zu Frankfurt am Main. (Adres: Stadtbibliothek).

Verein für Erdkunde, Kassel.

Verein für Naturkunde, Kassel.

Verein für Erdkunde, te Metz.

Historisch-litterarischer Zweigverein des Vogesenciubs in Elsass-Lothringen, Strassburg. (Adres: Kaiserliche Universitäts- \& Landesbibliothek zu Strassburg i. Els.)

Kedactie der „Mitteilungen aus Justus Perthes' Geographischen Austalt, ’|'te Gotha.

Königl. Gesellschaft der Wissenschaften zu Göttingen.

Verein für Erdkunde, te Halle an der Saale.

Vereiu für Erdkuude zu Leipzig (Brüderstrasse 23).

Deutsche Morgenländische Gesellschaft, Halle a. S.

Königliche Academie der Wissenschaften, te München.

De Redactie vau de „Orientalische Bibliographie” Redacteur Prof. Dr. A Müller, Halle (Saale) Mühlgraben 4a.

De Redactie van het Zeitschrift für wissenschaftliche Geographie (Red. J. I. Kettler), Weimar (Thüringen).

Wurttembergischer Verein für Handelsgeographie, Stuttgart.

Nassauische Verein tür Naturkunde. (Adres; Dr. A. Pagenstecher, Seecrtär des Nassauischen Vereins für Naturkunde). Wiesbaden. 
Geographische Gesellschaft für Thüringen, Jena.

Kaiserliche Akademie der Wissenschaften, te Weenen.

Anthropologische Gesellschaft, te Weenen.

K. K. Geographische Gesellschaft, in Wien, I, Universitätsplatz No. 2.

K. K. Naturhistorische Hofmuseum, Weenen. (Wien, 1, Burgring).

Verein der Geographen an der Universität Wien.

Redactie van de Oesterr. Monatsschrift für den Orient, te Weenen (Red. A. Baron von Scala.)

\section{ENGELAND, BRITSCH-INDIË, CHINA, AUSTRALIË.}

Royal Colonial Institute, Northumberland Avenue, London W. C.

India Office, te Londen.

Royal Asiatic Society, 22 Albemarlestr. W., Londen.

Royal geographical Society, Burlingt. Gard. W., Londen.

Anthropological Institute of Great Britain and Ireland, Loudon (3, Hanover Square).

Redactie van de „Proceedings of the Royal Geographical Society and

Monthly Record of Geography.” (Clements R. Markham, te Londen.)

Scottish Geographical Society, Edinburgh.

Anthropological Society of Bombay. (6, Appollo street, Bombay).

Asiatic Society of Bengal, Asiatic Society's Rooms, 57 Park Street, Calcutta.

Straits Branch of the Royal Asiatic Society, Singapore, Straits Settlements.

Ceylon Branch of the Royal Asiatic Society, te Ceylon.

North China Branch of the Royal Asiatic Society, te Shanghas.

Public Library of Victoria, te Melbourne.

Royal Society of Victoria, te Melbourue.

Tokio Geographical Society, te Tokio, Japan.

Société des études Indo-Chinoises de Saigon.

\section{A.MERIKA.}

American geographical Society, te New-York.

Smithsonian Institution, Washington, U. S. A.

Director of the United States Geological Survey, Washington, D. C. U. S. A. American Academy of Arts and Sciences, Beacon street, Boston, Massachusetts. Sociedad Mexicana de geografia y estadistica, te Mexico.

Canadian Institute, Toronto (46 Richmondstreet East). 


\section{STE BESTUURSVERGADERING,}

GEHOUDEN 19 MAART 1892.

Tegenwoordig de heeren: der Kinderen (Voorzitter), Kern (Ondervoorzitter), J. H. de Groot (Penningmeester), N. F. van den Berg, L. W. C. van den Berg, Kielstra, Niemann, Schlegel, Quarles van Ufford, Vreede en Wijnmalen (Secretaris). Afwezig de heer van der. Pant.

De notulen van het verhandelde in de vorige gewone en buitengewone Bestuursvergadering worden gelezen en goedgekeurd, waarna de notulen van het verhandelde in de Algemeene Vergadering worden medegedeeld en voorloopig gearresteerd.

Door den Secretaris wordt de aandacht gevestigd op de sedert de vorige bijeenkomst ingekomen boekwerken, terwijl zijn ontvangen een nr. van het Bataviaasch Nieuwsblad van 21 Januari 1892, waarin eene aankondiging van "het Minangkabausch-Maleisch-Nederlandsch Woordenboek van den heer J. L. van der Toorn"; en een nr. van de Deli-Courant van 3 Februari 1892, bevattende een opstel over "Prof. Schlegel en de Karo-Bataks."

Ter lezing gedeponeerd.

De Voorzitter deelt mede dat ontvangen zijn missives:

$1^{\circ}$. enz.

$2^{\circ}$. van de hh. Jhr. mr. W. C. A. Alberda van Ekenstein, H. H. Beels, H. A. van Beuningen, N. D. J. Bezemer, G. M. Boissevain, P. ten Bosch, J. G. P. Cambier, D. Cordes, G. Diepen, G. Emants, B. L. Gomperts, F. L. S. van Heekeren, H. C. Hintzen, H. J. Hijmans, H. H. Juynboll, Jhr. Mr. A. L. J. Melvill van Carnbee, A. J. Nijland, A. M. Oudemans, E. A. Staëll van Holstein van Vloten, M. T'eixeira de Mattos, Mr. C. Th. Thurkow, Dr. P. J. F. Vermeulen, W. A. Baron van Versehuer, Jhr. G. $5_{\text {e }}$ Voigr. VII. 
G. de Villeneuve, Mr. W. A. van der Vlugt, F. A. de Vriese en .J. W. Wilson, allen houdende kennisgeving van de aanvaarding van het lidmaatschap van het Instituut.

$3^{\circ}$. van den heer H. Sundermann, laatstelijk zendeling op het eiland Nias, thans te Moers a/Rh., houdende mededeeling van de aanvaarding van zijne benoeming tot correspondeerend lid van het Instituut, onder dankbetuiging tevens voor de heu bewezen onderscheiding.

$4^{\circ}$. van den heer L. C. A. Rombach, te Batavia, berichtende het lidmaatschap van het Instituut te aanvaarden.

Al deze missives sub $1^{\circ} .-4^{\circ}$. worden voor kennisgeving aangenomen.

50. van den heer W. C. Blanken, asp. Controleur bij het B. B., tijdelijk toegevoegd aan den Inspecteur der Cultures, belast met de leiding der proefneming eener nieuwe landrenteregeling in de Preanger-regentschappen, te Bandoeng, houdende verzoek als lid van het Instituut te worden ingeschreven met ingang van 1 Januari 1892.

Dienovereenkomstig wordt zonder beraadslaging besloten.

$6^{\circ}$. enz.

7 ${ }^{\circ}$ van den heer C. B. van de Wal, te Amsterdam, houdende kennisgeving van de verandering zijner woonplaats.

Van het in de missives sub $6^{\circ}$. en $7^{\circ}$. medegedeelde zal aanteekening worden gehouden.

Ter tafel wordt gebracht een schrijven van den Commissaris-thesaurier van het Instituut te Batavia, waarbij worden aangeboden twee prima-wissels, de een groot $f 551.60$ en de andere $f 418.95$ Ned. Courant, beiden betaalbaar als gebruikelijk.

In handen gesteld van den Penningmeeter, terwijl de ontvangst daarvan zal worden erkend.

Van den Minister van Koloniën is, in antwoord op een dezerzijds ingediend rekwest van 2 Januari 1892 om eene Regeeringssubsidie ten behoeve van de uitgave van het verslag van den ontgravings- 
arbeid van den voet der tempels van de Tjandi-groep te Prambanan, onder voorwaarde dat van het werk vijftig exemplaren ter beschikking van de Regeering zullen worden gesteld, - eene missive ontvangen dd. 27 Februari jl, Lett. $A^{1}, n^{\circ} .31$, waarbij ter kennis van het Instituut wordt gebracht dat zijn verzoek wordt ingewilligd, wordende de aangeboden photographiën en kaarten daarbij tevens teruggezonden.

Met belangstelling wordt door de vergadering van dit besluit kennis genomen, en wordt de Secretaris gemachtigd het noodige te verrichten voor de uitgave van bedoeld plaatwerk.

In aansluiting aan de reeds in de laatste Algemeene Vergadering gedane mededeeling brengt de Voorzitter ter tafel een schrijven van den Minister van Koloniën d.d. 30 Februari ji., liett. A. No. 6, waarin Z. Exc. mededeelt, dat blijkens een van den GouverneurGeneraal van Nederlandsch-Indië ontvangen telegram voor het loopende jaar eene Regeerings-subsidie van $f 10.000$ is verleend ten behoeve van het vanwege het Instituut ondernomen wetenschappelijk onderzoek vau de eilanden der Bandazee.

Dit schrijven wordt voor kennisgeving aangenomen, terwijl, overeenkomstig het voorstel van den Voorzitter, besloten wordt den ontvangst van het besluit van den Gouverneur-Generaal af te wachten, alvorens aan den Landvoogd den dank van het Instituut te betuigen voor de genomen beschikking, onder aanbeveling wijders van het bereids aangevangen onderzoek.

De Secretaris doet eenige mededeelingen uit een door hem van den hoogleeraar Martin ontvangen brief uit Saparoea van den Sen $^{\text {s. }}$ Januari 1.1.

Met belangstelling verneemt de vergadering de berichten omtrent het onderzoek en vereenigt daarna zich eenparig met de gedane voordracht om den heer K. H. F. Roos, Controleur te Saparoea, tot lid van het Instituut te benoemen.

De ondervoorzitter, Prof. Kern, brengt ter tafel een brief van Anquetil du Perron, waarvan slechts 'een gedeelte door Prof. Houtsma in dl. 37 der Bijdragen openbaar was gemaakt. Thans in de gelegenheid gesteld tot de mededeeling van den geheelen brief, met eenige daaromtrent verstrekte inlichtingen van Dr. H. Hamaker, geeft de hoogleeraar Kern in overweging hem daartoe in de eerstvolgende April-aflevering der Bijdragen een plaats te verleenen.

Dienovereenkomstig wordt besloten. 
Het Bestuurslid, Prof. Schegel, doet mededeeling van een door tusschenkomst van zijn ambtgenoot, Prof. Dr. J. J. M. de Groot, ontvangen brief van een Deenschen geleerde, Lubbers, houdende verzoek om inlichtingen, of er voor een zuiver anthropologisch onderzoek over de Gorontaleezen ook eene plats zou kunnen ingeruimd worden in de Bijdragen van het Instituut.

Uit de hierover gevoerde beraadslaging blijkt dat de vergadering van oordeel is, dat zuiver anthropologische bijdragen niet in de eerste plaats thuisbehooren in het Tijdschrift van het Instituut, terwijl de raad moet gegeven worden zich daartoe bij voorkeur te wenden tot de redactiën van de natuur- of geneeskundige tijdschriften hier te lande, in Indië of elders verschịjnende.

Niets meer hierna aan de orde zijnde, wordt de vergadering door den Voorzitter gesloten.

\section{2ste BESTUURSVERGADERING,}

\section{GEHOUDEN 21 MEI 1892.}

Tegenwoordig de hh.: Kern (Ondervoorzitter), J. H. de Groot (Penningmeester), I. W. C. van den Berg, Niemann, Quarles van Ufford, Vreede en Wijnmalen (Secretaris). Afwezig de hh. der Kinderen, N. P. van den Berg, Kielstra, van der Pant en Schlegel.

Bij ontstentenis van den heer der Kinderen, Voorzitter, wegens ziekte, neemt de Ondervoorzitter, prof. dr. Kern, diens plaats in, op wiens verzoek de notulen van het verhandelde in de vorige vergadering worden gelezen en goedgekeurd, waarna wordt medegedeeld, dat is ontvangen:

een overdruk uit de Economist van het bestuurslid Quarles van Ufford over het Panamakanaal;

een academisch proefschrift van den heer C. J. Schüssler, bevattende "eenige opmerkingen naar aanleiding van art. 223 van het Inlandsch
Reglement; 
een exemplaar van het Bataviaasch Nieuwsblad van 7 April 1892, waarin een opstel, bevattende "Indrukken van de jongste Algemeene Vergadering van het Koninklijk Instituut voor de taal-, land- en volkenkunde van Nederlandsch Indië"”;

eene missive van den Minister van Binnenlandsche Zaken, 30 April 11. La. A., afd. K. W. ten geleide van vervolgwerken, voor het Instituut ontvangen van de Fransche Commissie voor internationalen ruil van boekwerken te Parijs;

eene missive van de Koninklijke Academie van Wetenschappen te Amsterdam van 27 April 11. $\mathrm{n}^{\circ}$. 17 , ten geleide van deel XX1X der Verhandelingen, afd. Natuurkunde; van de Verslagen en Mededeelingen, afd. Natuurk., $3^{\mathrm{e}}$ Reeks, Deel IX. 2; afd. Letterk., $3^{\mathrm{e}}$ Reeks, Deel VIII 3 en Jaarboek 1891, onder dankbetuiging tevens voor de toezending der laatstelijk verschenen Bijdragen tot de taal-, land- en volkenkunde van N.-I., 5 $5^{\mathrm{e}}$ Reeks, deel VII, afl. 1;

eene missive van den Bibliothecaris van het Teyler's Museum, houdende aanbieding van de $7^{\mathrm{e}}$ afl., III ${ }^{\mathrm{e}}$ deel, $2^{\mathrm{e}}$ serie van de Archives du Musée Teyler;

missives van de Directie van het Musée Guimet, te Parijs, ten geleide van de Revue de l'Hist. des Religions, T. XXIII, n ${ }^{\circ} .3$ en XXIV, $\mathrm{n}^{\circ}$. 1 en 2 ;

eindelijk, eene missive van den boekhandelaar Otto Harrasowitz in Leipzig, ten geleide, namens het Gouvernement van Madras, van een exemplaar van de South Indian Inscriptions, vol. II, I.

Plaatsing der verschillende boekwerken in de Bibliotheek onder dankbetuiging aan de inzenders.

De tijdelijke Voorzitter deelt mede, dat nog is ontvangen:

$1^{\circ}$. eene missive van den Bibliothecaris van het Historisch Genootschap, gevestigd te Utrecht, hondende bericht van ontvangst van de Bijdragen, Ve deel, afl. 1-4.

20. eene missive van de Directie van de Académie Royale des sciences de Lisbonne, houdende dankbetuiging voor de toegezonden Bijdragen, 1892, 5e volgr., VII. 1.

Beide missives worden voor kennisgeving aangenomen.

$3^{\circ}$. eene missive van den Minister van Buitenlandsche Zaken, dd. 26 April $1892, \mathrm{n}^{\circ}$. 982 , afd. K. W., waarbij wordt medegedeeld dat het Koninklijk Instituut te Napels tot de uitgave besloten 
heeft van eene verzameling van werken in de Italiaansche taal, ten dienste van hen, die zich op de studie der Oostersche talen wenschen toe te leggen; het eerste deel dezer verzameling, bevattende eene Hindostansche spraakkunst, zal weldra verschijnen. Door den Italiaanschen Gezant is eene opgave verzocht van de geleerde instellingen hier te lande die genegen zouden zijn tot eene ruiling van dergelijke boekwerken met het Koninklijk Instituut voornoemd. Gaarne zou men in de gelegenheid gesteld worden hieromtrent voor zoover het Indisch Instituut betreft. bericht te ontvangen.

$\mathrm{Na}$ gedachtenwisseling wordt besloten af te wachten wat er vanwege het Instituut te Napels wordt uitgegeven, alvorens een geregeld letterkundig verkeer aan te knoopen.

4\%. eene missive van de firma Hachette en Cie. te Parijs, houdende verzoek tot ruiling van het tijdschrift van het Instituut met den Tour du Monde en de daaraan verbonden Nouvellles géographiques. Dienovereenkomstig wordt besloten.

$5^{\circ}$. missives van de hh. leden P. K. W. Kern, te Garoet, F. Pompe van Meerdervoort, C. van der Gon Netscher en J. H. J. Sigal, allen houdende bericht van de verandering hunner woonplaats.

Voor kennisgeving aangenomen.

6. missives van de hh. J. M. Pijnacker Hordijk, Dr. W. A. Terwogt en Jhr. C. van der Wijck, houdende bericht van de aanvaarding van het lidmaatschap van het Instituut.

\section{7o. enz.}

De missives sub $5^{\circ}-7^{\circ}$ worden voor kennisgeving aangenomen.

Ter tafel wordt gebracht een briefkaart van Dr. J. Brandes, Commissaris van het Instituut, te Batavia, waarbij het verzoek wordt overgebracht van den heer P. M. L. de Bruyn Prince, ass.resident te Ambarawa, om hem tot lid van het Instituut voor te dragen, met ingang van 1 Januari dezes jaars.

Dienovereenkomstig wordt besloten, terwijl mede tot lid wordt voorgedragen en benoemd de heer mr. E. Gadsonides, rechterlijk Ambtenaar op Java, thans met verlof hier te lande.

Met referte aan het schrijven van het Instituut van 21 September 


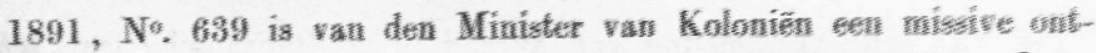
vangen dd. 20 April $\mathrm{j} 1$. Lett. $A, \mathrm{n}^{\circ} .19$, wasbij worlt melegedeeld, dat, blikkens een van den Couvemenr-Generad wan Nederlandsch-Indie ontvangen bericht, de heer J. L, wan der Them te zijner bijd door eene platsing bij het lager onderwijs in de residentie Padangsehe Bovenlanden in de galegenheid zal wonlen gesteld ou zijne studièn van het Minangkabausdi faaleigen voert te zetten.

Deze missive word voor 表ernisgewing asngenomen.

Ter tafel worlt gebracht cen door tusschen van Koloniēn ontvangen Rxtract wit het Wegister der Mesiniten nan den Gouvemenr-General van Nederlandech-Indie, gedagteckend Tuitenzorg, 18 Pebruari 18k2, No, 12, warsan de inhwul is als volgt:

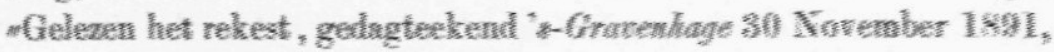
van het Koninklijk Institunt woor de tad- land- en volkenkande ran Vederlandsch-Indié;

"De Raad van Nederlandsch-Indië gehoord.

"Is goedgevonden en verstaan:

"Aan het Koninklijk Instituut voor de taal- land- en volkenkunde van Nederlandsch-Indië te 's-Gravenhage, voor het jaar 1892 toe te keunen een subsidie van $f 10000$ (tien duizend gulden), ten einde het genootschap in staat te stellen met behulp van dit bedrag het reeds aangevangen wetenschappelijk onderzoek van de eilanden der Banda-zee, bedoeld bij artikel 1 van het besluit van 16 Juni 1891 $\mathrm{n}^{\circ} .23$, te doen voortzetten;

"onder voorwaarde dat de bij het onderzoek te maken verzamelingen, na voor zooveel noodig bewerkt of beschreven te zijn, ter beschikking van de Indische Regeering zullen worden gesteld of op Hare aanaauwijzing aan Nederlandsche musea zullen worden afgestaan.

"Extract dezes zal worden verleend aan het Koninklijk Instituut voor de taal- land- en volkenkunde van Nederlandsch-Indië tot informatie.

"Accordeert met voors. Register.

\section{De Gmivernements Secretaris,}

(w. g.) D. F. UHLENBECK."

Voor kennisgeving aangenomen, terwijl alsnu zal worden gevolg gegeven aan het in de vorige vergadering genomen besluit, om den Gouverneur-Generaal van N. I. den dank van het Instituut aan te bieden voor Zijner Excellentie's gunstige beschikking. 
De Secretaris brengt ter tafel twee uitvoerige door hem van den hoogleeraar Martin omtrent zijn onderzoek ontvangen brieven van 12 Februari en 1 Maart 1892, en deelt den voornamen inhoud daarvan mede.

De tijdelijke Voorzitter zegt den Secretaris dank voor zijne mededeelingen, waaraan door hem nog een en ander wordt toegevoegd uit een nader te Leiden door Mevrouw Martin ontvangen schrijven, waarvan een uittreksel zal worden geplaatst in het Algemeen Handelsblad.

Van den Uitgever Martinus Nịhoft, te 's Gravenhage, is een schrijven ontvangen, houdende mededeeling, dat hem van verschillende zijden, zoo hier te lande als in Indië, gewezen wordt op het wenschelijke van een herdruk, in één deel, van al de opstellen van Prof. Wilkeu, door het Instituut uitgegeven. Wanneer het Instituut daartoe de bevoegdheid heeft, komt het hem voor, dat ook nit een handelsoogpunt weinig of geen risico aan een dergelijken herdruk zal verbonden zijn, terwijl daarmede een belangrijke dienst aan de beoefening der volkenkunde kan bewezen worden. Mocht het Bestuur daartoe genegen bevonden worden, dan zal men zich gaarne met de samenstelling der uitgaaf belasten en daaromtrent een bepaald voorstel met berekening van omvang, format, drukkosten doen toekomen.

$\mathrm{Na}$ eenige gedachtenwisseling wordt, overeenkomstig het voorstel des Voorzitters, besloten den heer Nijhoff, onder dankbetuiging voor het door hem gedaan aanbod, mede te deelen dat er voor het Instituut geene termen zijn daarvan gebruik te maken.

De Secretaris bespreekt de uitgave van het werk des heeren L. van de Polder, waaromtrent hij aan het Bestuur mededeelingen doet, naar aanleiding waarvan de vraag wordt gesteld of het niet geraden zou zijn terug te komen op het vroeger genomen besluit tot uitgave van voormeld werk.

$\mathrm{Na}$ beraadslaging wordt deze vraag in bevestigenden zin beantwoord en den Secretaris opgedragen dienovereenkomstig te handelen, onder kennisgeving tevens aan den heer van de Polder van het besluit der Vergadering.

Van het medelid, H. A. de Nooy, Schoolopziener bij het Inlandsch onderwijs in Ned. Indië, thans met verlof hier te lande, is onder dagteekening van 21 Mei jl. het volgend schrijven ontvangen : 
"Ik heb de eer hierbij aan te bieden eene Javaansche Woordenlijst, bevattende in de eerste plaats woorden, welke in de residentiën van Midden-Java buiten Soerakarta gebruikt worden met verschil van beteekenis; in de tweede plaats woorden, welke uitsluitend in enkele streken buiten Soerakarta gehoord worden en eindelijk die, welke in Soerakarta in gebruik, dan wel in andere residentiën, doch niet voorkomen in het Javaansch Woordenboek van wijlen Professor T. Roorda. Waar het noodig bleek, zijn hier en daar de woorden in zinnen gebracht, ten einde het verschil van beteekenis meer duidelijk te doen uitkomen.

"Ten einde voortdurende herhalingen en overtolligheid te vermijden, heb ik de namen der gewesten, afdeelingen en onderafdeelingen verkort angegeven, waarom $i k$ zoo vrij ben eene lijst der voorkomende verkortingen hierbij aan te bieden.

"Mocht het werk waardig gekeurd worden eene kleine bijdrage te zijn tot nadere kennis der Javaansche taal en in zoo verre eene plaats vinden in het Tijdschrift, zoo zou ondergeteekende hiermede zijn doel bereikt hebben en zou het voor hem eene aanmoediging zijn om bij terugkomst op Java uitbreiding te geven aan deze proeve, wanneer hij daartoe in de gelegenheid werd gesteld.

"Ten zeerste houd ik mij dan ook aanbevolen, omtrent het laatstgenoemde, ter gelegener tijd, Uwe door mij hooggewaardeerde zienswijze te mogen vernemen."

De aangeboden Javaansche woordenlijst wordt in handen gesteld van de hh Kern en $\nabla$ reede, ten einde der vergadering met bekwamen spoed te dienen van bericht en raad omtrent de wenschelijkheid en, eventueel, ook omtrent de wijze der uitgave daarvan.

De Secretaris brengt ter tafel een schrijven van den heer G. de Waal, te Montrado, waarin hem de vraag wordt voorgelegd, of het Bestuur van het Instituut genegen zoude zijn de uitgave op zich te nemen van een Nederlandsch-Minangkabausch woordenboek.

Uit de gedachtenwisseling, die naar aanleiding dezer vraag wordt gevoerd, blijkt, dat het Instituut, in de eerste tijden althans, te veel werkzaamheden te verrichten heeft, reeds zoovele uitgaven in uitzicht heeft gesteld of wel bereids ondernomen, dan dat het mogelijk zou zijn alsnog een werk van zulk een omvang als het bedoelde uit te geven, daargelaten nog de vraag, of en in hoeverre het wenschelijk kan geacht worden zulk een arbeid vanwege het Instituut te doen bezorgen. 
Overeenkomstig het voorstel van den Voorzitter wordt den Secretaris opgedragen het medelid de Waal van een en auder mededeeling te doen.

Het Bestuurslid Niemann brengt verslag uit omtrent een in zijne handen gestelde bijdrage over "een bezoek aan de Bataksche hoogvlakte", door den heer Engelbert van Bevervoorde. Zij bestaat uit eene bewerking der aanteekeningen, die tot grondslag gestrekt hebben voor een uitvoerig rapport, aan het Legerbestuur ingediend door den Overste van de Pol, Militair Kommandant van Sumatra's Oostkust. Met goedkeuring van dezeu heeft de heer van Bevervoorde dit stuk aan het Instituut ter publiceering gezonden. Het bezoek van de hoogvlakte had plaats in Maart 1891 en is dus het nieuwste bericht omtrent deze landstreek. Om deze reden, alsmede owdat het, ofschoon zeer kort, eenige hier en daar niet onbelangrịke mededeelingen behelst, die in vroeger verschenen stukken omtrent dit gedeelte der Bataklanden niet voorkomen, meent men te moeten adviseeren dit opstel in de Bijdragen op te nemen.

Dienovereenkomstig wordt zonder beraadslaging besloten, terwijl tevens de Secretaris gemachtigd wordt het opstel op te nemen in de October-aflevering der Bijdragen tegelijk met de stukken der heeren Pleyte en Kielstra.

De Voorzitter brengt ter tafel een tweetal bijdragen van Sydney H. Ray, behelzende: $1^{\circ}$. Vocabulary of the Tangoa dialect, en $2^{\circ}$. Melanesian text, with literal translations and notes. Gaarne zou hij omtrent eene uitgave daarvan vanwege het Instituut het gevoelen van het Bestuur vernemen.

Wordt besloten de stukken om bericht en raad in handen te stellen van den heer Niemann.

Niets meer hierua aan de orde zijnde, wordt de vergadering door den Voorzitter gesloten. 


\section{STE BEST'UURSVERGADERING,}

GEHOUDEN 18 JUNI 1892.

Tegenwoordig de hh.: der Kinderen (Voorzitter), Mr. L. W. C. van den Berg, Kern, Kielstra, Niemann, Quarles van Ufford, Schlegel, Vreede en Wijnmalen (Secretaris). Afwezig de hh.: N. P. van den Berg, J. H. de Groot en van der Pant.

De Voorzitter, de heer der Kinderen, opent de vergadering en wenscht het Bestuurslid Vreede geluk met de hooge onderscheiding, hem ten deel gevallen vanwege de Rijks-Universiteit te Leiden, door zijne benoeming, honoris causa, tot doctor in de Indische taal-, land- en volkenkunde. Door toejuiching vereenigt de vergadering zich met de bewezen hulde.

Vervolgens worden de notulen van het verhandelde in de vorige vergadering gelezen en goedgekeurd, waarna de aandacht wordt gevestigd op de ingekomen boekwerken en tijdschriften, terwijl medegedeeld wordt dat ontvangen is :

$1^{\circ}$. eene missive van den Minister van Binnenlandsche Zaken, dd. 3 Juni 1892, $\mathrm{n}^{\circ}$. 1332, afd. K. W., ten geleide van twee pakketten met boeken voor het Instituut bestemd, ten vervolge ontvangen van de Fransche Commissie voor internationalen ruil van boekwerken te Parijs.

$2^{\circ}$. eene misive van de Directie van het Musée Guimet, ten geleide van de: Revue de l'histoire des Religions, T. XXIV, $\mathrm{n}^{\circ} .3$; de deelen XIX en XX van de "Annales du Musée Guimet", met de "Introduction au catalogue du Musée Guimet."

Voor kennisgeving aangenomen, met plaatsing der boeken en tijdschriften in de Bibliotheek.

Ter tafel wordt gebracht een schrijven van de Archaeologische Vereeniging te Jogjokarta van 5 Mei 1892, $\mathrm{n}^{\circ}$. 13, waarbij $1^{\circ}$. wordt kennisgegeven van de samenstelling van het Bestuur der Vereeniging, met verzoek voortaan alle brieven en andere stukken te adresseren aan den Secretaris G. J. Oudemans; en 2o. onder 
mededeeling dat de photograaf Cephas van de verschillende tempels van Prambanan en van de schoonste bas-reliefs photographieën vervaardigd heeft, waarvan echter geen stel aan de musea en geleerde genootschappen geschonken kan worden, de Vereeniging echter gaarne hare tusschenkomst zal willen verleenen om op aanvrage van het Instituutsbestuur, een volledig stel dier photographieën te bezorgen tegen den voor leden van de Vereeniging zeer gering gestelden prijs van $f 30$.- Het stel bestaat uit: $1^{\circ}$. 24 photographieën van den tempelwand op de hoogte van den rondgaanden gang; $2^{\circ}$. 24 photographieën van den binnenwand der borstwering, die den buitenkant van genoemdeu rondgaanden gang vormt; en $3^{\circ}$. zestien photographiën van tempels van de Prambanan-groep, of gedeelten daarvan met de verklaringen achterop geschreven.

$\mathrm{Na}$ eenige gedachtenwisseling wordt besloten: $1^{\circ}$. van de mededeeling sub $\mathrm{J}^{\circ}$. aanteekening te houden en van het sub $2^{\circ}$. gedaan aanbod gebruik te maken, wordende aan het Bestuur der Vereeniging overgelaten over het geldswaardig bedrag te zijner tijd te beschikken op de wijze, zooals dit hem wenschelijk zal voorkomen.

Van Dr. Arthur de Claparède, President van het Aardrijkskundig Genootschap te Genève, is eene circulaire ontvangen houdende bericht eener uitgave van een Jaarboek, waarin een overzicht van de organisatie, werkzaamheid en andere gewenschte mededeelingen omtrent de bestaande geo- en ethnografische genootschappen zullen worden opgenomen, met verzoek tevens de noodige opgaven omtrent het Instituut te willen verstrekken.

De Secretaris deelt mede, dat bereids door invulling en terugzending van het bij de circulaire gevoegde billet aan het gedane verzoek is voldaan.

Nog zijn brieven ontvangen van de hh: M. Bock, Mr. M. S. van Nierop, J. J. van Santen, Mr. B. R. W. A. Baron Sloet van Hagensdorp en S. Stibbe, allen te Amsterdam, berichtende dat zij gaarne als leden wenschen toe te treden.

De Secretaris brengt ter tafel een schrijven van Commissarissen van het Instituut te Batavia van den $10^{\mathrm{n}}$ Mei ll., waarbij aangeboden worden twee prima-wissels, groot respectievelijk $f 498.75$ en $f 349.13$ N. C., betaalbaar als gewoonlijk.

De wissels zijn bereids in handen gesteld van den Penningmeester, 
die de aandacht er op meent te moeten vestigen, dat dusver nog geene afsluitings-rekening over de jaren 1890-91 werd ontvangen, waarom, na gedachtenwisseling, overeenkomsig zijn voorstel, wordt besloten, in het antwoord aan Commissarissen, behelzende de ontvangsterkenning der twee genoemde wissels, hun aan te bevelen aan des Penningmeester's verzoek te willen voldoen.

Aan de vergadering worden aangeboden eenige gedrukte stukken betreffende nitnoodigingen tot deelneming aan

$1^{\circ}$. het geographisch congres te Genua met daaraan verbonden tentoonstelling in de maand September a. s.;

$2^{\circ}$. het $9^{\mathrm{e}}$ international Orientalisten-Congres, $5-12$ Sept. a. s. te Londen te houden; en

$3^{\circ}$. het $10^{\mathrm{e}}$ internationaal Orientalisten-Congres, van 23 Sept. tot 1 Oct. a. s. te Lissabon te houden.

Een en ander wordt voor kennisgeving aangenomen, terwijl de Voorzitter en Secretaris worden gemachtigd, om, wanneer soms een of meer Bestuursleden een der gemelde Congressen mochten wenschen bij te wonen, hun alsdan een mandaat als vertegenwoordiger van het Instituat uit te reiken.

De Secretaris deelt mede opnieuw een schrijven van den hoogleeraar Martin te hebben ontvangen, ditmaal uit Wahaai onder dagteekening van 13 April jl. Van den inhoud van dit schrijven wordt door de vergadering met belangstelling kennis genomen, alsmede ook van een nader schrijven dat haar door tusschenkomst van het Bestuurslid Kern werd medegedeeld.

In aansluiting aan de mededeelingen des heeren Martin omtrent den wetenschappelijken onderzoekingstocht geeft de Secretaris een overzicht van hetgeen sedert daarvoor verricht werd. Daaruit blijkt dat in de eerste plaats, na ontvangst van het besluit der Indische Regeering van 13 Februari 1892, $\mathrm{n}^{\circ}$. 12, waarbij de subsidie van $f 10.000$ werd toegekend, onder dagteekening van 25 Mei 1.l. $\mathrm{n}^{\circ}$. 776 , een schrijven aan den Gouverneur-Generaal werd gericht, houdende daukbetuiging voor de door Zijne Excellentie genomen beschikking, terwijl het Instituut zich voorstelt eerlang ook voor het dienstjaar 1893 anvrage te doen tot beschikking over de subsidie ten behoeve van het in te stellen ethnografisch onderzoek.

Omtrent dit laatste is voorts dd. 17 Maart 1.1. no. 768 een schrijven 
gericht aan den Resident van Amboina, G. W. W. C. Baron van Hoëvell, waarin hem: $1^{\circ}$. de vraag werd onderworpen, of hịj zich met bedoeld onderzoek zou willen belasten, ter uitvoering van welke taak door hem slechts een vergunning tot het doen van onderzoekingen binnen den kring van zijn gewest aan de Indische Regeering zou behoeven aangevraagd te worden; en $2^{\circ}$. mocht de Resident daartoe genegen worden bevonden, alsdan het Bestuur langs telegrafischen weg met het enkele woord "gewenscht" zijn besluit mede te deelen.

Naar aanleiding van dit schrijven werd daarop een telegram ontvangen, bevattende de woorden: "gewenscht; conditions", waarna onverwijld èn aan den Gouverneur-Generaal van N.-I. èn aan den heer Van Hoëvell, dd. 25 Mei ll. onder de nrs. 777. en 778 de volgende brieven zijn gericht:

1. aan den Gouver-Generaal van Ned.-Indië

\section{"Excellentie!}

"Was het voor het Koninklịk Instituut voor de taal-, land-, en volkenkunde van N.-I. een voorrecht door Uwer Excellentie's besluiten van 16 Jnni 1891, No. 23 en 13 Februari $1892, \mathrm{~N}^{\circ} .12$, in staat te worden gesteld het wetenschappelijk onderzoek van de eilanden der Banda zee te doen ondernemen en voortzetten, door het diep betreurd overlijden van den hoogleeraar Dr. G. A. Wilken. wien het geographisch en ethnografisch gedeelte van 't onderzoek zou zijn opgedragen, moest naar een plaatsvervanger worden omgezien. Aanvankelijk meende het Instituut die taak te kunnen en te mogen opdragen aan Dr. H. ten Kate, die thans nog in Indië reizende is ten behoeve van het Aardrijkskundig genootschap. Doch redenen van verschillenden aard deden de aanvankelijk met dien geleerden Reiziger gevoerde onderhandelingen onzerzijds afbreken.

"Het is ons echter aangenaam Uwer Excellentie te mogen mededeelen, dat wij in Indië zelf, en wel in den heer G. W. W. C. Baron van Hoëvell, Resident van Amboina, een deskundige hebben gevonden, die zich bereid verklaart het voorgenomen ethnografisch onderzoek in te stellen.

"Althans zoo Uwe Excellentie hem zou kunnen vergunnen, met behoud van zijn ambt, binnen den kring van zijn gewest bedoelde onderzoekingen in te stellen en de noodige reizen te doen.

"Is bereids eene dergelijke aanvraag aan Uwer Excellentie's overweging door den Resident van Amboina aangeboden, het zịj aan ons vergund haar bij Uwe Excellentie met eerbiedigen aandrang aan te bevelen en te ondersteunen. 
"Door zijne groote bekendheid ter plaatse en de instelling van het onderzoek binnen den kring van zijn gewest zal het den Resident van Hoëvell gemakkelijk vallen bij de warmeming van zijn ambt zich tevens van de vervulling der bedoelde taak te kwijten, welke tevens geen lang tijdsverloop zal behoeven te vorderen.

"Het Koninklịk Instituut hoopt, dat het Uwer Excellentie behagen moge de gevraggde vergunning te verleenen, waardoor Uwe Excellentie de Indologische wetenschap opnieuw an zich zal verplichten.

"Uwe Excellentie gelieve inmiddels de betuiging onzer eerbiedige hoogachting te aanvaarden."

2. aan den heer Baron van Hoevell:

\section{"Hoog WelGeb. Heer!}

"Dezer dagen mochten wij Uw telegrafisch bericht ontvangen, waaruit ons tot onze vrengde bleek, dat $U$ de taak van wijlen den hoogleeraar Wilken op $U$ zoudt willen nemen. Het Bestuur wenscht het Instituut daarmeê geluk, overtuigd als het is, dat het voorgenomen ethnografisch onderzoek thans aan deskundige handen zal worden toevertrouwd.

"In Uw telegram wordt gewag gemaakt van de "conditiën." Hieromtrent kunnen wij $U$ echter niets naders mededeelen dan hetgeen in ons schrijven van 17 Maart 11., $\mathrm{n}^{\circ}$. 768, voorkwam.

"Wat allereerst de geldmiddelen betreft, waarmeê de kosten van het onderzoek zullen moeten worden bestreden, voor 't loopend dienstjaar is ons de subsidie van $f 10.000$ toegestaan, waarvan minstens de helft alsnog moet ten bate komen van Prof. Dr. Martin. De andere helft zou ter Uwer beschikking kunnen worden gesteld, terwijl ter bekwamer tijd voor 1893 bij de Regeering het verzoek zal worden gedaan alsnog $f 10.000$ voor bedoeld onderzoek ter beschikking te willen stellen, waartoe bereids de Indische Regeering het uitzicht geopend heeft in haar Besluit van $16 \mathrm{Juni}$ 1S91, no. 23, zoo althans de Indische Begrooting voor 1893 daartoe de gelegenheid zal geven.

"Het lijdt geen twijfel, of met zulk eene subsidie zullen de kosten van het ethnografisch onderzoek voldoende kunnen worden gedekt, te meer waar dat onderzoek verricht wordt door het Hoofd van bestuur binnen den kring van zijn gewest.

"Aan welke voorwaarden voorts de Indische Regeering ons Instituut bindt, blijke U uit bijgaand afschrift van Haar Besluit. Voornamelijk geldt het de bij het onderzoek te maken verzamelingen, waartegen bij $\mathrm{U}$ wel geen bezwaar zal bestaan. 
"Gelịjk wịj U reeds in ons eerste schrịjven hebben doen opmerken, zou door $U$ slechts eene vergunning tot het doen van bedoelde onderzoekingen en de noodige reizen binnen den kring van $\mathrm{Uw}_{w}$ gewest aan de Indische Regeering behoeven aangevraagd te worden. Daar ongetwijfeld zulk eene aanvrage bereids door $U$ zal zijn ingediend, hebben wij gemeend haar bij den Gouverneur-Generaal van N.-I. te moeten steunen, gelijk U blijken kan uit een schrijven aan dien Landvoogd, waarvan een afschrift hierbij gaat.

"Andere of meerdere conditiën kunnen wij onzerzijjds althans, U niet mededeelen of stellen.

"Het zal ons aangenaam zijn weldra van $U$ bij een ampel schrijven te mogen vernemen dat wij het voorrecht genieten, dat door $U$ het ethnografisch onderzoek zal worden op het touw gezet na bespreking met den hoogleeraar Martin, wiens werk weldra zal zijn verricht.

"Gaarne grijpen wij tevens deze gelegenheid aan om, waar de hoogleeraar Martin ons steeds wees op Uwe krachtige hulp en gewaardeerde adviezen bịj zịnn onderzoek, $U$ daarvoor den oprechten dank van het Instituut te betuigen.

"Gelief ook de onder U ressorteerende Ambtenaren, voor zoover zij den hoogleeraar hebben gesteund, van onze erkentelijke gevoelens te doen blijken.

"Inmiddels verzoeken wij $\mathrm{U}$ de betuiging onzer hoogachting te willen aanvaarden."

Onder dankzegging aan den Secretaris worden zijne mededeelingen voor kennisgeving aangenomen:

Omtrent het in de vorige vergadering ingekomen opstel, getiteld: "Vocabulary of the Tangoa-dialect, Espiritu Sancto, New Hebrides, compiled bij Sydney H. Ray" brengt de hoogleeraar Niemann schriftelijk rapport uit, daarbij adviseerend het stuk in de Bijdragen op te nemen als eene bijdrage tot de kennis van talen die verwant zijn met die van Polynesië en den Indischen Archipel.

Zonder beraadslaging vereenigt de vergadering zich met dit advies.

De heer Quarles van Ufford vestigt de aandacht der vergadering op de bibliographie der koloniale literatuur, die sedert enkele jaren in den Indischen Gids van de hand des heeren $I_{\text {. }}$. de Petit werd opgenomen, doch die sedert den aanvang van dit jaar daarin geene plaats meer vindt. 
Het nut eener dergelijke uitgave in het licht stellende en de staking daarvan betreurende, oppert de heer Quarles het denkbeeld, of niet het tijdschrift van het Instituut daarvoor eene rubriek zou kunnen openen, in welk geval de heer de Petit te zijner tijj eene officieële aanvrage tot het Bestuur zou richten.

De heeren Kern en Wijnmalen lichten het door den heer Quarles gesprokene nader toe, met verwijzing ook naar de sedert eenige jaren uitgegeven wordende "Orientalische Bibliographie" die in de bestaande behoefte schịnt te voldoen.

Hoewel men het belang der meergemelde uitgave wilde erkennen, achtte men het echter met 't oog op het vele, waarvoor telkens eene plaats wordt gevraagd, minder wenschelijk telkens in de Bijdragen eene niet geringe plaats daarvoor te moeten afzonderen.

Bovendien zou men het niet zonder bedenking achten, de bibliographie, gelijk die tot dusver was ingericht, daarin op te nemen, wijl zij ook titels van werken aanwijst, die betrekking hebben op al de vreemde koloniën; slechts bij eene aanmerkelijke inkrimping van den arbeid, met weglating dier bedoelde titels, zou opneming daarvan gewenscht kunnen worden.

De heer Kern neemt op zich den heer de Petit van den loop der gevoerde beraadslagingen mededeeling te doen.

De heer Schlegel zegt eenige mededeelingen te willen uitgeven over de betrekking der Chineezen met Java, en zou gaarne daarvoor eene plaats zien ingeruimd in de a. s. October-aflevering. Daartegen wordt geen bezwaar gemaakt.

Overeenkomstig het voorstel des heeren Niemann wordt de heer E. van Assen, Controleur $1^{\mathrm{e}}$ klasse, met verlof alhier, tot lid benoemd, met ingang van Januari 1892.

Niets meer hierna aan de orde zijnde, wordt de vergadering door den Voorzitter gesloten. 